San Jose State University

SJSU ScholarWorks

Master's Theses

Master's Theses and Graduate Research

1993

\title{
The study of idioms and its application to ESL and intercultural communication
}

Yōko Itō

San Jose State University

Follow this and additional works at: https://scholarworks.sjsu.edu/etd_theses

\section{Recommended Citation}

Itō, Yōko, "The study of idioms and its application to ESL and intercultural communication" (1993).

Master's Theses. 632.

DOI: https://doi.org/10.31979/etd.jnxy-8edr

https://scholarworks.sjsu.edu/etd_theses/632

This Thesis is brought to you for free and open access by the Master's Theses and Graduate Research at SJSU ScholarWorks. It has been accepted for inclusion in Master's Theses by an authorized administrator of SJSU ScholarWorks. For more information, please contact scholarworks@sjsu.edu. 


\section{INFORMATION TO USERS}

This manuscript has been reproduced from the microfilm master. UMI films the text directly from the original or copy submitted. Thus, some thesis and dissertation copies are in typewriter face, while others may be from any type of computer printer.

The quality of this reproduction is dependent upon the quality of the copy submitted. Broken or indistinct print, colored or poor quality illustrations and photographs, print bleedthrough, substandard margins, and improper alignment can adversely affect reproduction.

In the unlikely event that the author did not send UMI a complete manuscript and there are missing pages, these will be noted. Also, if unauthorized copyright material had to be removed, a note will indicate the deletion.

Oversize materials (e.g., maps, drawings, charts) are reproduced by sectioning the original, beginning at the upper left-hand corner and continuing from left to right in equal sections with small overlaps. Each original is also photographed in one exposure and is included in reduced form at the back of the book.

Photographs included in the original manuscript have been reproduced xerographically in this copy. Higher quality $6 " \times 9^{\prime \prime}$ black and white photographic prints are available for any photographs or illustrations appearing in this copy for an additional charge. Contact UMI directly to order.

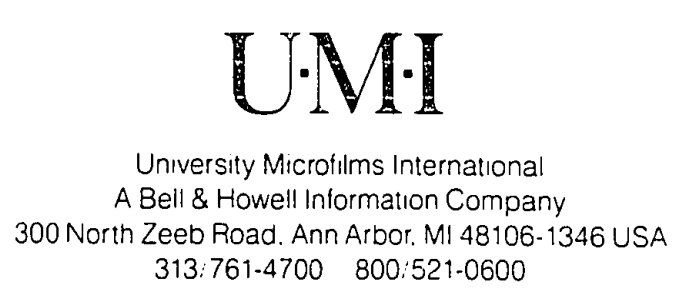



Order Number 1854147

The study of idioms and its application to ESL and intercultural communication

\author{
Ito, Yoko, M.A.
}

San Jose State University, 1993

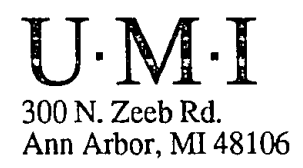


THE STUDY OF IDIOMS

AND ITS APPLICATION TO

ESI AND INTERCULTURAL COMMUNICATION

\begin{abstract}
A Thesis
Presented to

The Faculty of the Department of Communication Studies

San Jose State University
\end{abstract}

In Partial Fulfillment

of the Requirements for the Degree

Master of Arts

By

Yoko Ito

August, 1993 
APPROVED FOR THE DEPARTMENT

OF COMMUNICATION STUDIES

chester 李文淑

Dr. Wen-Shu Lee

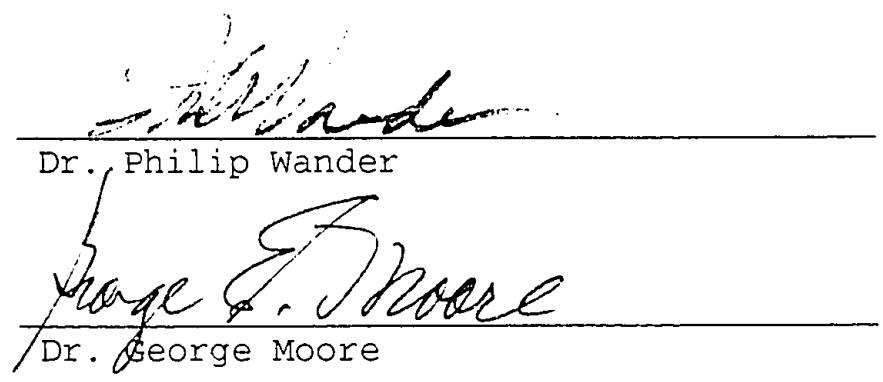

APPROVED FOR THE UNIVERSITY

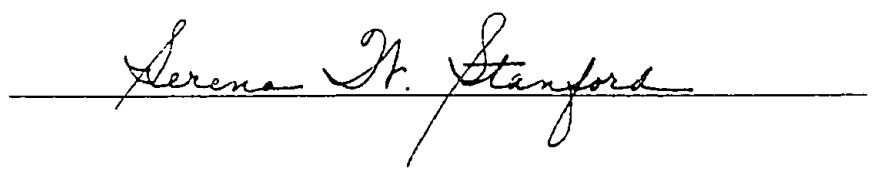


ABSTRACT

THE STUDY OF IDIOMS

AND ITS APPLICATION TO

ESL AND INTERCULTURAL COMMUNICATION

By Yoko Ito

This study first explains non-native speakers'

difficulty with idiom comprehension from the psycholinguistic perspective. Then it points out that the ESL literature neglects interpersonal relationships indicated by idioms. It also takes the position that one of the barriers to building a close intercultural relatiorship might lie in the idiom use.

Three video clips (formal, natural, and idiomatic versions) were created and shown to both native and nonnative college students $(\underline{N}=168)$ to empirically explore the link between the use of idioms and perceptions of interpersonal relationships via Knapp's dimensions in an intercultural context.

The results show significant differences in comprehension and ability to use idiomatic speech style, perceived interpersonal relationships, identification of what age group of people used each speech style, and comfortableness in using idioms in selected locations between native and non-native speakers of English.

Implications of this research to ESL and communication research are discussed. 
ACKNOWLEDGEMENTS

I thank Dr. Wen-Shu Lee, my advisor, who supported me to do socially meaningful research. I am grateful to you for inspiring me to pursue a degree in communication. I also thank Dr. Philip wander and Dr. George Moore, my committee members, both of whom supported and encouraged me.

I am grateful to Michelle Bach, Mark Bach, Lisa Ives, Lisa Whitney, and Hiroko Tabuchi, for helping me to create video clips.

I am grateful to the faculty and students of the Department of Communication Studies for their cooperation.

I thank Yushi Kaneda for his encouragement and computer expertise.

I thank Rob Dewis, Marianne Neuwirth, Tasha Souza, and Laurel Joakimides, for proofreading my thesis.

I thank Jeff Carlberg and Mayumi Enoki, who have been supportive friends from the beginning.

I thank Penrods, Juels, Kevin Bariteau, and Ruby Goodnight, my American families, for their hospitality, support, and good humor.

I thank members of Pacific Neighbors of San Jose and International Friendship Association of Okayama, Japan for giving me the opportunity to stay and study in San Jose.

Einally, I thank Hajime Ito and Tatsuji Ito, my parents, for their financial support and commitment to higher education. Mom, Dad, I love you. 


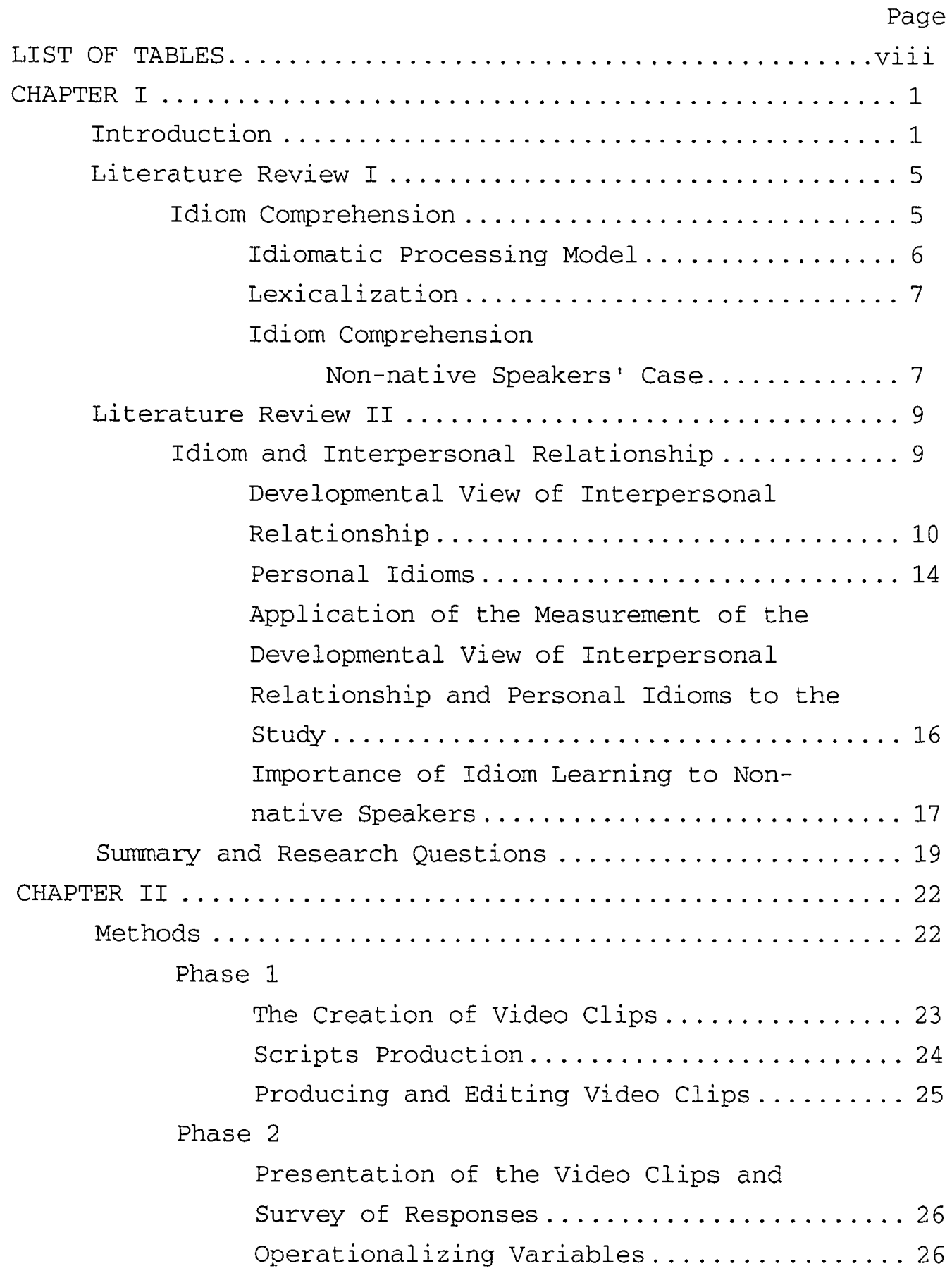


Questionnaire Construction and Face

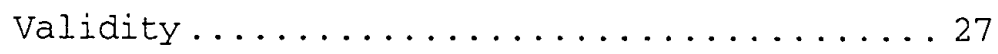

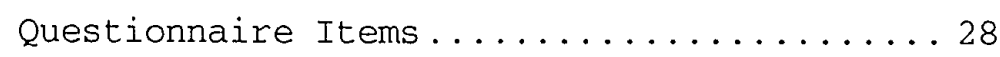

Demographics.................. 29

Idiom comprehension. . . . . . . . . 29

Perceived interpersonal

relationship................. 29

Use of idioms.................. 30

Intercultural experience......... 30

Design....................... 30

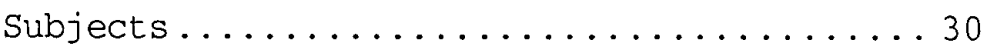

Procedure.................... 32

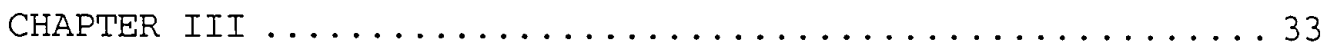

Results ........................... 33

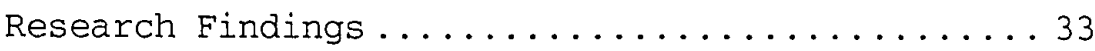

Two-Way Analyses of Variance.......... 33

One-Way Analyses of Variance........... 35

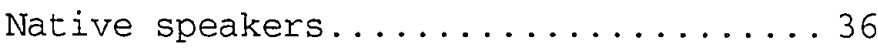

Non-native speakers................ 36

Significance of Mean Differences for

Native and Non-native Speakers......... 37

Formal version................. 38

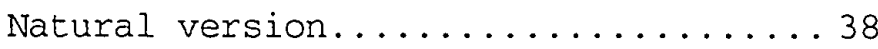

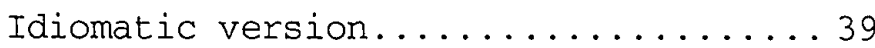

Mean Differences for Native and Non-

native Speakers' Idiom Use..........41

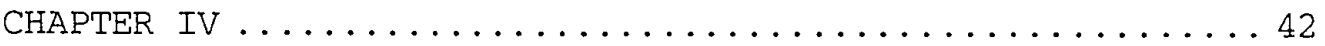

Discussion ......................... 42

Research Question 1: Comprehension ......... 42

Research Question 2: Ability ............. 43

Research Question 3: Perceived Interpersonal

Relationship...................... 44

Research Question 4: Generation

Identification ................ 46

vi 
Research Question 5: Use of Idioms........48

Summary ............................ 49

Recommendations to $\mathrm{ESL} \ldots \ldots \ldots \ldots \ldots \ldots \ldots \ldots \ldots \ldots$

Implication to Communication Research ........... 52

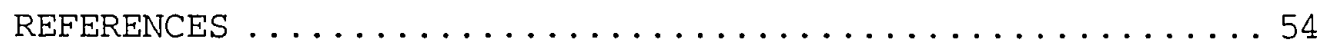

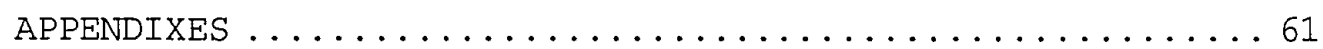

APPENDIX A Three Scripts for the Video Clips .......662

APPENDIX B Questionnaires for Native and Non-native

Speakers of English .................. 66

APPENDIX $C$ Tables ..................... 80 
FIGURE in CHAPTER I

1.1 Developmental view of interpersonal relationship.....11 TABLE in CHAPTER II

2.1 Experimental conditions ................... 30

TABLES in CHAPTER III

3.1 Main and interaction effects between status and stimulus . . . . . . . . . . . . . . . . . . 34

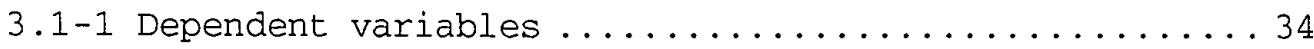

3.2 Native and non-native speakers' responses across

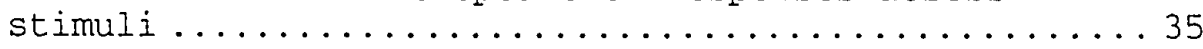

3.3 Significance of mean differences of dependent variables for native and non-native speakers ...... 37

3.4 Results of t-tests for comfortableness in using idioms in selected locations .............. 41

TABLES in APPENDIX C

C.1: Two-Way ANOVA $\ldots \ldots \ldots \ldots \ldots \ldots \ldots \ldots \ldots \ldots \ldots \ldots \ldots$

1.1. Comprehension ....................... 81

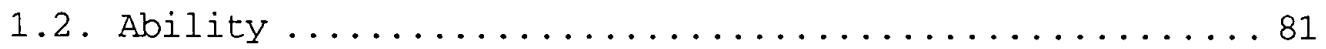

1.3. Informality ...................... 81

1.4. Efficiency ........................ 82

1.5. Flexibility $\ldots \ldots \ldots \ldots \ldots \ldots \ldots \ldots \ldots \ldots \ldots \ldots \ldots \ldots \ldots$

1.6. Smoothness ...................... 82

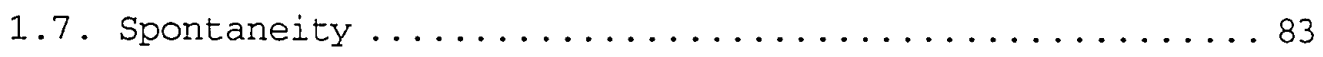

1.8. Closeness ........................... 83

1.9. Female teen-agers .................... 83

1.10. Female college students ................. 84

1.11. Middle-aged women ..................... 84 
1.12. Female senior citizens $\ldots \ldots \ldots \ldots \ldots \ldots \ldots \ldots \ldots . \ldots 4$

C.2: One-Way ANOVA: Native Speakers $\ldots \ldots \ldots \ldots \ldots \ldots . . \ldots 5$

2.1. Perceived interpersonal relationship ............ 85

2.2. Perceived interpersonal relationship ............ 85

2.3. Perceived interpersonal relationship ........... 85

2.4. Perceived interpersonal relationship ............ 85

2.5. Perceived interpersonal relationship ............ 86

2.6. Perceived intexpersonal relationship ............ 86

2.7. Generation identification $\ldots \ldots \ldots \ldots \ldots \ldots \ldots \ldots, 86$

2.8. Generation identification .................. 86

2.9. Generation identification .................. 87

2.10. Generation identification .................. 87

C. 3 One-Way ANOVA: Non-native Speakers .............. 88

3.1. Comprehension by speech style ............... 88

3.2. Ability by speech style $\ldots \ldots \ldots \ldots \ldots \ldots \ldots \ldots, \ldots 8$

3.3. Perceived interpersonal relationship ............ 88

3.4. Generation identification .................. 88

C.4 T-tests: Formal Version ...................... 89

4.1. Comprehension ............................ 89

4.2. Ability $\ldots \ldots \ldots \ldots \ldots \ldots \ldots \ldots \ldots \ldots \ldots \ldots \ldots \ldots$

4.3. Perceived interpersonal relationship (Informality) ...89

4.4. Perceived interpersonal relationship (Efficiency) ... 89

4.5. Perceived interpersonal relationship (Flexibility) ...89

4.6. Perceived interpersonal relationship (Smoothness) ... 9 96

4.7. Perceived interpersonal relationship (Spontaneity) ...90 
4.8. Perceived interpersonal relationship (Closeness) ....990

4.9. Generation identification (Female teen-agers) .......90

4.10. Generation identification (Female college

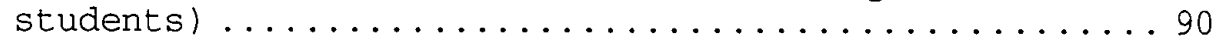

4.11. Generation identification (Middle-aged women) ......91

4.12. Generation identification (Female senior citizens) ........................... 91

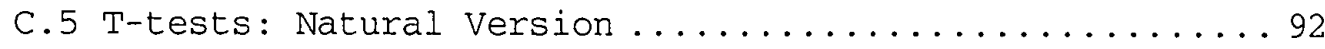

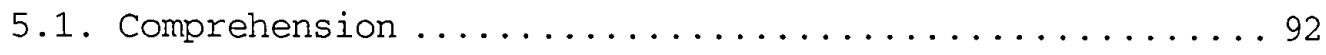

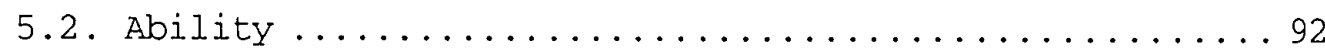

5.3. Perceived interpersonal relationship (Informality) ... 92

5.4. Perceived interpersonal relationship (Efficiency) ... 92

5.5. Perceived interpersonal relationship (Flexibility) ... 92

5.6. Perceived interpersonal relationship (Smoothness) ...993

5.7. Perceived interpersonal relationship (Spontaneity) ...93

5.8. Perceived interpersonal relationship (Closeness) ....93

5.9. Generation identification (Female teen-agers) ......993

5.10. Generation identification (Female college students) ........................... 93

5.11. Generation identification (Middle-aged women) ......994

5.12. Generation identification (Femaie senior

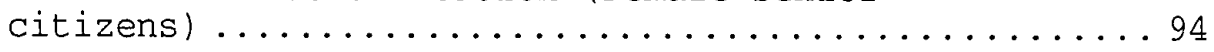

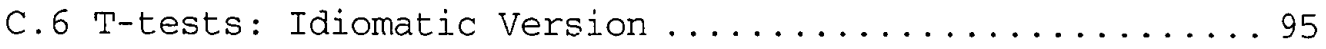

6.1. Comprehension ...................... 95

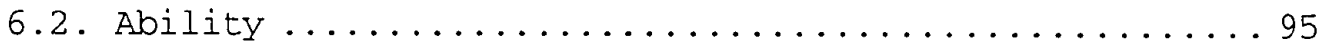

6.3. Perceived interpersonal relationship (Informality) .. 95

6.4. Perceived interpersonal relationship (Efficiency) ... 95

6.5. Perceived interpersonal relationship (Flexibility) ... 95 
6.6. Perceived interpersonal relationship (Smoothness) ...996

6.7. Perceived interpersonal relationship (Spontaneity) .. 96

6.8. Perceived interpersonal relationship (Closeness) .... 96

6.9. Generation identification (Female teen-agers) .......96

6.10. Generation identification (Female college

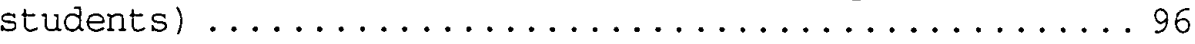

6.11. Generation identification (Middle-aged women) .....997

6.12. Generation identification (Female senior citizens) ............................. 97

C.7 T-tests: Comfortableness in Using Idioms ......... 98

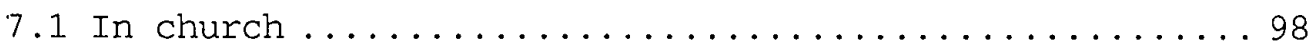

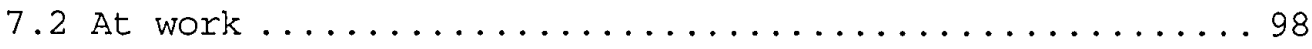




\section{Introduction}

Native and non-native speakers of English often experience communication breakdown when they interact with one another. "What's cooking?" "Your goose is cooked." "John kicked the bucket." "Ross Perot threw his hat in the ring." Non-native speakers are usually confused or lost in the midst of conversation when they come across such idioms.

Lynch (1988) states that native speakers who used idioms with native speakers opted to replace such items when talking to non-native speakers at lower English proficiency levels. Native speakers modify their use of idioms. For example, instead of saying "having cottoned on to their joke, " native speakers use "then the man decided it was a big joke and he started laughing" for non-native speakers.

Lynch also points out that it is not uncommon to find native speakers who talk to non-native speakers as if nonnative speakers were on a different intellectual plane, not simply linguistically disadvantaged.

These examples allude to the distant relationship between native and non-native speakers of English related to the use and avoidance of idioms. In other words, according to Knapp (1984), their message exchange is difficult, the flow of the conversation is awkward, and the conversation is not spontaneous. 
The researcher's daily encounter of intercultural communication supports Lynch's ideas. The researcher would like to share her own experience which inspired this study. Like many foreign students in American universities, the Japanese researcher has been studying at San Jose State University for three years while living with several American families. The first family had two high school students. They were the researcher's American brother and sister. The researcher was often lost in the midst of conversation with them, feeling left out and stupid. This experience was attributed to the lack of English ability, rather than to a lack of culturally specific knowledge about the conversation. Having realized they used idioms, including teen-age slang, the researcher tried to ask for meanings of unfamiliar idioms. Sometimes they were good teachers and enjoyed teaching idioms. However, the researcher's intention of reaching out for knowledge was occasionally discouraged by their answers, such as, "Never mind. It's just a silly American expression." Limited recognition of idioms and inability to use them kept the researcher behind a thick wall of isolation among Americans.

The stage of active learning of idioms arrived when the researcher had another American brother. He was twenty-one years old and used many idioms. He liked to talk and share stories. Therefore, the researcher felt comfortable asking him questions in the midst of conversation. Whenever 
unfamiliar idioms popped up, the conversation was stopped and he provided meanings of the idioms. Although he had to scratch his head sometimes in order to find the best explanation, he was always willing to explain meanings of various idioms. The idiom vocabulary gradually improved and the researcher started to use some idioms. Then the feelings of being at home, of joy, and of happiness emerged and they began knocking down the thick wall of isolation in American culture.

The researcher experienced a change in interpersonal relationships through the use of idioms. English classes in Japan did not teach idioms. Therefore, formal English was the only option for the researcher when she first came to the United states. Americans were likely to talk back in a formal manner. Consequently, interpersonal relationships were rigid, distant and awkward. The conversation consumed much energy on both sides. After the researcher started using idioms, however, American friends became more relaxed and sometimes swore in front of the researcher That was phenomenal! The use of idioms played a role of breaking the ice. Interpersonal relationships became more flexible, close, and smooth. There was more laughter and things to share in the relationships. The use of idioms brought happier interpersonal and intercultural relationships. There are many non-native speakers of English who study hard at American universities without experiencing close 
intercultural relationships. They may feel that they are stuck in their English language acquisition. Even advanced non-native speakers of English are not aware that they are stuck or why. They are not able to strike up a conversation with native speakers naturally. By the same token, American students do not know why it is awkward to talk with foreign students. They do not realize the interpersonal relationships indicated by the use of idioms.

An intercultural communication class and a seminar dealing with humor and idiom research at San Jose State University conducted by Dr. Lee, marked the beginning of a systematic dialogical exploration of idioms. Lee's (1992) qualitative exploration of how to explain the meanings of idioms interculturally helped the researcher to enrich her idiom vocabulary and daily conversation with Americans. It also initiated the present study which empirically attempts to explore the link between the use of idioms and perceptions of interpersonal relationship via Knapp's (1984) dimensions in an intercultural context.

This study intends to show that one of the barriers to building close intercultural relationships between native and non-native speakers of English lies in problems related to idioms used in conversation. It provides three scripts which contain the same message using three different speech styles; formal, natural, and idiomatic ones. It asks if native and non-native speakers of English can differentiate and detect 
the nature of interpersonal relationship according to the speech style. In addition, this study asks if native and non-native speakers of English can comprehend and produce the three speech styles.

The remainder of this chapter reviews literature in two areas. The first literature review deals with idiom comprehension from ESL (English as a Second Language) and the perspectives of psycholinguistics. The second literature review explores idiom and interpersonal relationships from ESL and the viewpoints of interpersonal communication. At the end of this chapter, the research questions that guide this project will be presented.

\section{Literature Review I Idiom Comprehension}

This section introduces idiomatic processing models and lexicalization in order to illustrate how native speakers comprehend idioms. In addition, non-native speakers' difficulty in idiom comprehension will be described based on the inapplicability of idiom processing models and lexicalization to non-native speakers.

As Silc (1990) states, ESL literature recognizes that idiomatic phrases are the most difficult part of any language to learn because the meaning behind each word usually has nothing to do with the words spoken. According to Celona (1983), non-native speakers mention idioms as a hindrance in their communication. 
Lee (1992) reviewed psycholinguistic literature to examine how people process idioms. She reported three idiomatic processing models. Also, she illustrated lexicalization. The followings are the digest of her review. Idiomatic Processing Model

Idioms, a special form of human verbal communication, have been studied by socio- and psycholinguists over the past decade (Cacciari \& Jabossi, 1988; Gibbs, Nayak, \& Cutting, 1989; Glass, 1983; Mueller \& Gibbs, 1987; Schraw, Trathen, Reynolds, \& Lapan, 1988; Schweigert \& Moates, 1988).

Schweigert and Moates (1988) define idioms as common expressions used in colloquial speech with accepted, figurative meanings that differ from their present-day literal meanings. For example, the idiomatic meaning of the idiom kick the bucket is "to die," while the literal meaning is "to strike a pail with the foot" (p.281).

According to Schweigert and Moates (1988), three theoretical models have been proposed by scholars to help understand how people process idioms. The first model is called Literal-then-Figurative Processing Model. Bobrow and Bell (1973) suggest that people have an "idiom word dictionary." In other words, idioms are stored as single lexical items. This model of idiom comprehension indicates that an idiom is processed literally first; if the meaning does not match the context, it is interpreted figuratively by accessing one's "idiom word dictionary." 
The second model is called Simultaneous Processing Model. Swinney and Cutler (1979) suggest that people store idioms as single lexical units. This model claims that an idiom is processed literally and figuratively at the same time.

The third model is called Figurative-then-Literal Processing Model. Gibbs (1980) suggests that the literal meaning of the idioms is of less importance in idiom comprehension because idioms have strong conventional figurative meanings. This is the opposite of the first model. An idiom is processed figuratively first, and only if the meaning is inappropriate to the context is it then interpreted literally. Lexicalization

Schraw, Trathen, Reynolds, and Lapan (1988) claim that one has to be capable of lexicalization, which means developing wordlike units in lexical memory for idioms in order to comprehend them. In other words, it is the process by which a word or a recognizable phrase becomes easily identified as being wordlike in meaning. Idiomatic meanings develop wordlike units whereas literal meanings do not. Idiom Comprehension: Non-native Speakers' Case

Lee states that the three models presented: Literalthen-Figurative Processing Model, Simultaneous Processing Model, Figurative-then-Literal Processing Model, deal only 
with native speakers' idiom comprehension. Researchers assume that people already possess an "idiom word dictionary" or store idioms in single lexical units and neglect nonnative speakers' cases.

Schraw, et al., compared native and non-native speakers' idiom processing. They discovered that non-native speakers attempt to understand idioms using a word-by-word analysis, unlike native speakers. In other words, non-native speakers have not reached the lexicalization process yet. They have to rely solely on the literal interpretation of idioms. Lee explains this point through an example from Schraw, et al.: when attempting to paraphrase the meaning of chew the fat, one non-native speaker suggested that lifting weights helped chew fat off the body (p.421). The key here is that when non-native speakers come across an idiom, they look for its literal meaning; if it does not make sense in the given context, they get "confused" or "lost" in the conversation because they have no resort to the figurative interpretation. Thus, the idiom processing model for non-native speakers should be a Literal Processing only Model.

Lee also illustrates the difference in native and nonnative speakers' idiom comprehension. Native speakers do not have to go through literal meanings of single words when they interpret idioms because they have begun lexicalization. For instance, when a native speaker hears "hit the sack," he or 
she can draw the meaning "go to bed" without analyzing the verb "hit" or the noun "sack." Non-native speakers, however, have little access to lexicalization and they are baffled when they attempt to interpret the figurative meaning. They have to rely on their Literal Processing only model. They might ask, "Where is the sack?" or say, "Why?" due to the literal interpretation of the idiom. One can see that inability to interpret figurative meanings of idioms impairs the prospect of close relationships because it brings communication breakdown.

\section{Literature Review II}

\section{Idiom and Interpersonal Relationship}

Knapp (1984) indicates that most messages contain information about relationship and every human communication takes place within the context of some type of relationship. The point here is that the interpersonal relationship can be identified by the exchanged message.

This section explains Knapp's developmental view of interpersonal relationships in order to have a better understanding of the link between the interpersonal relationship and the exchanged message. Next, it introduces Hopper, Knapp, and Scott's (1981) personal idioms as one of the factors of the exchanged message. It then finds a connection between the developmental view of interpersonal relationships, idioms and the present study. This section 
also reinforces the importance of learning idioms from ESL iterature.

Developmental View of Interpersonal Relationship

Knapp (1984) proposes a measurement for the developmental view of interpersonal relationships. The concept of the measurement is that as relationships reach for more intimacy, communication becomes broad, unique, efficient, flexible, smooth, personal, and spontaneous. The opposite of these characteristics of communication indicates distant and deteriorating relationships. The measurement determines developing and decaying relationships by analyses of conversations using bipolar adjective criteria. An explanation of the bipolar adjective criteria needs to be provided. Knapp's diagram will show the general dimensions of communication behavior in developing and decaying relationships, and thus clarify our understanding of the measurement. 


\section{DECAY STAGES}

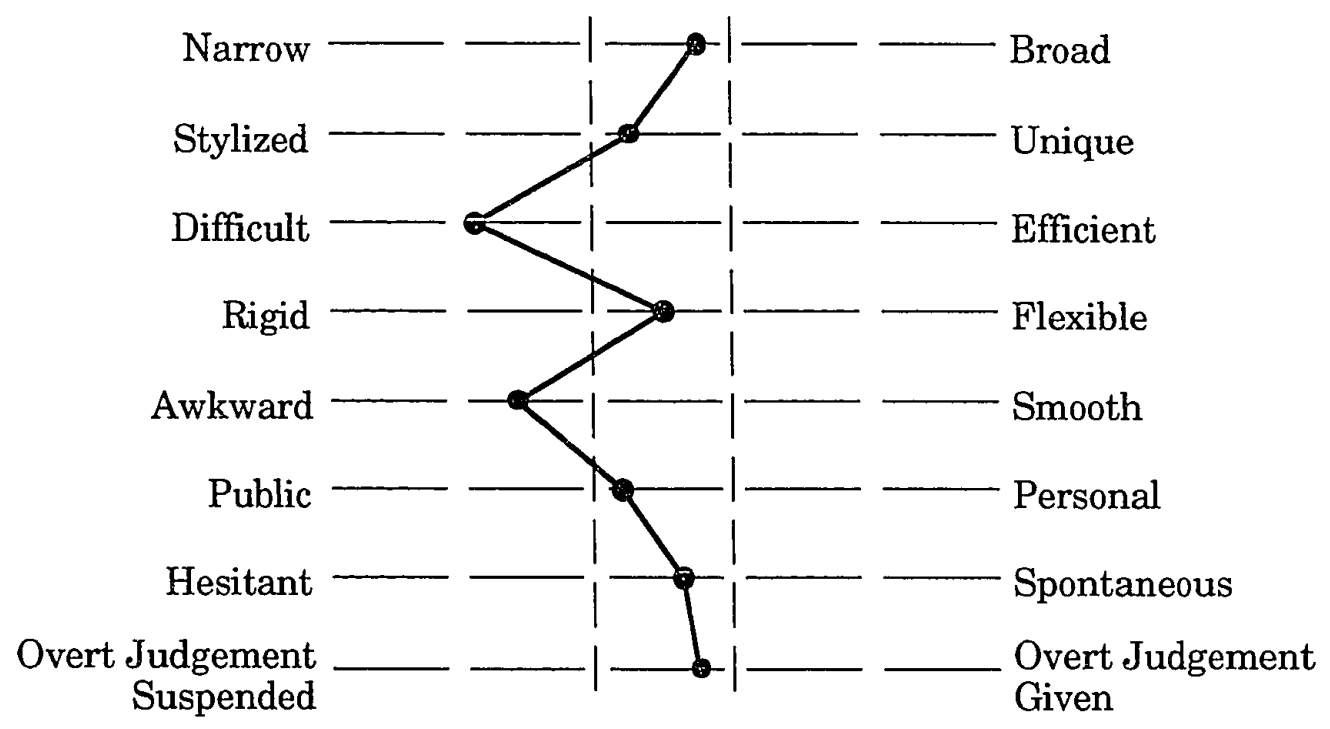

Figure 1.1 Developmental view of interpersonal relationship.

From Knapp (p. 20).

Narrow-Broad: "The amount of interaction with each category is referred to as breadth frequency. Thus, for any given situation, the number of categories opened up and the frequency of interaction within each category can be identified" (p. 14). During the growth stage of the interpersonal relationship, more topics are covered in various ways. For instance, facts, ideas, experiences, feelings, opinions, and attitudes could be exchanged with each other. On the other hand, the scope of the message exchange stagnates or decreases in a decaying relationship. 
Stylized-Unique: "Uniqueness in communication simply suggests the adoption of a more idiosyncratic communication system adapted to the peculiar nature of the interacting parties" (p. 16). An example of stylized or conventional behavior is a greeting expression, "How are you?" A formal relationship may employ "How are you?" Then, as the relationship becomes closer, "How's it going?" can be a gambit. The relationship may establish unique greetings over time. Also, the return of stylized behaviors is often observed in a deteriorating interpersonal relationship. Difficult-Efficient: "As a relationship grows and as more of the other person is revealed to us, there will be increased accuracy, speed, and efficiency in our communication" (p. 16). When the relationship becomes more intimate, less energy is required to communicate intended meanings.

Rigid-Flexible: "Flexibility simply refers to the number of different ways any given idea or feeling can be communicated" (p. 16). Close relationships have more flexibility in communication channels than distant ones. Awkward-Smooth: "As knowledge of the person increases, predictive ability also increases, which leads to greater synchronization of interaction. The comment, 'It was all very awkward,' is most likely directed at an interaction with a stranger, new acquaintance, or a situation experiencing the strain of decay" (p. 17). 
Public-Personal: "Initially, our public personality is revealed. Should the relationship move forward we will increasingly uncover more and more of our private or personal selves" (p. 17). This description can be applied to both verbal and nonverbal communication. People in decaying or distant relationships, however, try to shut off valves which may disclose personal information.

Hesitant-Spontaneous: "In close relationships, we find a communicative spontaneity--an informality, an ease of opening up oneself, a comfort in entering areas of the other person, a relationship that flows and changes direction easily" (p. 19). Partners in the new or deteriorating relationship, however, lack freedom and relaxation that may exist in the close relationship because they do not have communicative spontaneity.

Overt Judgement Suspended-Overt Judgement Given: "The closer the relationship, the greater the likelihood of freely giving and receiving positive and negative feedback" (p. 21). For example, first impressions of another person include some covert judgements. They are, however, usually unspoken until the relationship advances more.

The conversation between two people may reveal the stage of their relationship. The measurement of the developmental view of the interpersonal relationship helps us understand a link between exchanged message and intexpersonal relationship. 
Personal Idioms

One of the factors included in the exchanged message enabling us to determine the interpersonal relationship is background expectations between communicators. This section introduces personal idioms as background expectations from the communication literature explored by Lee (1992).

Garfinkel (1969) investigates "background expectations" in conversations among his students and their significant others. The subjects were asked to recall natural discourses in their intimate relationships, to identify the expressions that relied on shared background knowledge, and to replace the identified expressions with detailed explanations in communicating with significant others. The study suggests that if discourse partners can develop and share "short-hand communication" (messages that rely heavily on mutual background expectations), they are more likely to achieve closeness and intimacy. The idiom is a form of short-hand communication because its conventional meaning is shared by native speakers of English as the background expectation. The connection between short-hand communication and interpersonal relationship is validated by Hopper, Knapp and Scott's (1981) and Knapp's (1984) studies on personal idioms. Communication researchers (Hopper, et al.) report that personal idioms, such as certain words, phrases, and gestures, carry unique meanings only in the context of the 
intimate relationship. They analyzed personal idioms offered by their subjects according to their function. Couples use eight different types of personal idioms to express partner nicknames, expressions of affection, labels for others outside the relationship, confrontations, requests and routines, sexual references and euphemisms, sexual invitations, and teasing insults.

Knapp (1984) also adds that intimates develop an interpersonal jargon with private symbols and meanings known only to the intimate pair. Stated differently, words and phrases have special meanings for the pair while they are used commonly to others. Personal idioms serve to make the pair a more cohesive unit, that is, to reinforce the identity of the couple as something special or unique. In addition, personal idioms are an effective substitute for more direct and explicit terminology for issues that intimates need to address and they help a couple clarify relationship norms.

According to Hopper, et al., couples perceive the act of developing and using personal idioms as having a positive effect on their relationships. Knapp states: "The expression of ideas in a 'different way'--whether it is through the use of personal idioms or some other way--is perhaps the most evident difference in speech patterns between intimates and non-intimates" (p. 227).

Hopper and his colleagues found that personal idioms usually develop in the early stage of a relationship. They 
also found that when relationships sour, the meanings of personal idioms became modified and gradually extinguished. Thus, "personal idioms serve as an indicator of and a change agent for interpersonal relationships" (Lee, 1992, p. 3). Application of the Measurement of the Developmental View of Interpersonal Relationship and Personal Idioms to the Study

The measurement of the developmental view of interpersonal relationships has been explained in order for us to grasp the link between the interpersonal relationship and the exchanged message. Knapp (1984) only deals with interpersonal relationships among native speakers of English. None of the research in intercultural communication has applied Knapp's measurement. Moreover, no measurement of the developmental view of intercultural relationship has been proposed or established yet. The present study, therefore, uses Knapp's measurements for both interpersonal and intercultural relationships. To be more specific, first, video clips of two native speakers' conversation were produced. Second, native speakers viewed the clips and were asked to identify the perceived relationship of the two native speakers using the measurement of the developmental view of relationship. The measurement was used interpersonally in this case because native speakers evaluated the native speakers' relationship. Third, nonnative speakers viewed the clips and were asked to identify the perceived relationship of the two native speakers using 
the same measurement. The measurement was used

interculturally this time because non-native speakers

evaluated the native speakers' relationship.

Personal idioms have been spelled out as a manifestation of background expectations, which are included in the exchanged message, between communicators. They can help determine the interpersonal relationship. There are two things to point out about personal idioms and the present study. First, scholars have dealt with personal idioms only as native speakers use them. This study tries to explore intercultural relationships based upon native and non-native speakers' uses of idioms. Second, there is no research on idioms in general other than Lee's (1992) qualitative exploration of how to explain the meanings of idioms interculturally. The present study opens up a new dimension of idiom research in communication. It looks at a neglected area in intercultural communication: the relationship and use of idioms by native and non-native speakers of English, using a developmental view of interpersonal relationships and personal idioms. It is the first empirical attempt to explore the link between the use of idioms and perceptions of interpersonal relationships via Knapp's dimensions in an intercultural context. Importance of Idiom Learning to Non-native Speakers ESL literature discusses non-native speakers' difficulty in getting the hang of idioms and the importance of teaching 
idioms to non-native speakers of English. Viteli (1989) states the following:

English is very rich in idiomatic expressions. In fact, it is difficult to speak or write English without using idioms. An English native speaker is not aware that he is using an idiom; perhaps he does not even realise that an idiom which he uses is grammatically or semantically incorrect or for the foreigner hard to understand. A non-native learner has to make the correct use of idiomatic English one of his main aims, and the fact that some idioms are illogical or grammatically incorrect causes him difficulty. (p. 2)

Batt (1988) states that idioms could be substituted for phrases which do not contain them. It takes non-native speakers a long time to acquire and verbalize idioms while they have no problems with English without them. Some nonnative speakers never develop the courage to use idioms orally.

Radin (1985) reports that non-native speakers at the high-intermediate or advanced levels often get frustrated because they feel they are not making tangible progress or not learning anything. Their English may be grammatically correct but it is hardly idiomatic. ESL literature recognizes non-native speakers' problems with idioms as noted above. This motivates English teachers 
to teach more idioms to non-native speakers. One of the purposes of teaching idioms, according to Radin, is that idioms make non-native speakers sound more native-like and more part of the cultural milieu. Although these are good points to make, something important is neglected in ESL literature. That is, there is no mention about the link between idioms and the interpersonal relationship. The present study tries to support the importance of idiom learning in light of producing happier and better intercultural relationships by way of exploring idioms' role as an indicator of and a change agent in interpersonal relationships.

\section{Summary and Research Questions}

Literature Review I has illustrated how native speakers comprehend idioms through idiomatic processing models and lexicalization. Also, it has spelled out why non-native speakers fail to comprehend idioms based on the inapplicability of idiom processing models and lexicalization to them.

Literature Review II has explained the measurement of a developmental view of interpersonal relationship for a better grip on the link between interpersonal relationship and exchanged message. It introduces personal idioms as one of the elements in the exchanged message. It then provides guidance for the application of the measurement of the developmental view of interpersonal relationship and personal 
idioms to the present study. Finally, it reinforces the importance of learning idioms.

Besides trying to apply these points to communication research, this study hopes to facilitate closer and happier intercultural relationships through the use of idioms.

To this end, native speakers of English created an idiomatic script for college students who were both native and non-native speakers of English. In order to compare the idiom comprehension of those who are native and those who are not, native speakers also created formal and natural scripts for the same audience.

Three video clips were presented to college students, both native and non-native speakers of English, to measure their comprehension of the messages and perceived relationship of the communication partners in the scripts. Intercultural experience and use of idioms of the audience was also measured.

This chapter has explained non-native speakers' difficulty with idiom comprehension. It has also pointed out that the ESL literature neglected interpersonal relationships indicated by idioms. In addition, this chapter has taken the position that one of the barriers to building a close intercultural relationship between native and non-native speakers of English may lie in the use of idioms. Therefore, it explores the following research questions: 
RQ1: Will non-native speakers comprehend the conversation less than native speakers regarding each speech style? RQ2: Will non-native speakers be able to use each speech style less than native speakers?

RQ3: Will non-native speakers perceive interpersonal relationships differently from native speakers?

RQ4: Will non-native speakers identify what age group of people uses each speech style differently from native speakers?

RQ5: Will non-native speakers feel differently from native speakers in using idioms?

The research design and methods used to investigate these research questions are presented in the following chapter. 
CHAPTER II

Methods

Chapter I argued for non-native speakers' difficulty in idiom comprehension. It also argued that relationships indicated by the idiom were neglected in ESL so that nonnative speakers might have a different perception regarding the same relationship.

Given the literature reviewed and research questions raised in Chapter I, this project proceeded in two phases: (1) the creation of three video clips of native speakers' dialogues that might be responded to with differing degrees of comprehension and perceived relationship, and (2) a survey to measure the native and non-native speakers' responses to these dialogues in terms of comprehension, perceived relationship, and use of idioms.

The first phase of the project was to create a video clip of a dialogue between two female college students who were native speakers of English. It was produced by native speakers for both native and non-native speakers who were college students. To investigate difference in comprehension, perceived relationship, and the use of idioms, three versions were produced; formal, natural, and idiomatic. Gumperz (1970) has pointed out that the ability to select in terms of the formality of the appropriate style of speaking in the context of a particular interaction is very important. Three speech styles, therefore, were produced. To answer 
research questions, a conversational style was used in the scripts. An American couple cooperated to make natural, dialogical scripts. Also, two female graduate students were recruited to act out roles for the video production.

The second phase of this project involved measuring idiom comprehension, perceived relationship, use of idioms, and intercultural experience of college students who were either native or non-native speakers of English through a questionnaire. There are three reasons why college students were targeted in this study. First, a specific speech community was chosen. Gumperz (1970) states that verbal interaction is a social process in which spoken language is selected according to socially recognized norms and expectations. This concept is called "speech community," meaning any human aggregate characterized by regular and frequent interaction by means of a shared body of verbal signs and set off from similar aggregates by significant differences in language use. Individuals, therefore, are accepted as members of the speech community to the extent of their language use. Second, the target was narrowed down to avoid overgeneralization of the result. Third, this study hopes to lead foreign students to a happier campus life in America.

Phase 1: The creation of Video Clips

Since the researcher is a non-native speaker of English, she needed assistance from native speakers for the video 
production process. There were two stages taken for the process which need to be addressed here. The first stage was scripts production. The second stage was producing and editing video clips.

Scripts Production

A young American couple agreed to create three scripts for this project after being informed of the purpose of this study. In their twenties, just after graduation from university, they were familiar with the way college students talk and can relate to the topics discussed among close friends on campus. The couple was willing to devote one evening for the project with the researcher. The constraints to the scripts were (1) there had to be three versions containing the same information with different speech styles: formal, natural, and idiomatic version; (2) the topic in the conversation had to be typical for contemporary close friends; and (3) each conversation was to be limited to one minute. The couple came up with three scripts that met these constraints after discussion with each other. Each script began with two female students greeting each other in the classroom. They discuss what they want to do after class and decide to go shopping. They have a little quarrel but reconcile soon afterwards. Then they separate. The researcher asked several graduate students in Speech Communication to proofread the scripts. Some suggestions and 
comments were taken. Final versions of the scripts were completed after some minor changes were made.

Producing and Editing Video Clips

After a considerable search, two graduate students whose schedules did not conflict with each other were found. Both rad just graduated from college and are majoring in speech Communication. Their willingness and cheerful personalities were perfect for the role. They were assigned to memorize scripts and act out their own parts. They were told to dress as typical American college students. The only instruction for the acting was to be natural according to each speech style.

The two American students, an assistant who was a fellow graduate student, and the researcher got together in an empty classroom one afternoon to shoot the video clips. First, the two actresses were given time to rehearse until they felt comfortable acting in front of a video camera. Second, they acted out the formal version, several times. Then they did the natural version, followed by the idiomatic version several times. The video camera was running the whole time so that everything would be videotaped. The assistant paid attention to the sound and the lines of scripts. After about 45 minutes of this shooting session, the researcher and the actresses reviewed the videotape and agreed that there would be no better acting than had already been videotaped. 
Therefore, the researcher has chosen the best ones out of those taped.

After completing the videotaping for the three versions, the researcher edited the shots. The length of each version was approximately 50 seconds. The scripts for the video clips were transcribed in Appendix $A$.

Phase 2: Presentation of the Video Clips and Survey of

\section{Responses}

Operationalizing Variables

There were two independent variables (stimulus and status) and five groups of dependent variables (comprehension, ability, perceived relationships from knapp's measurement, generation identification, and comfortableness in using idioms). The first independent variable, the stimulus was divided into three treatment levels: formal version, natural version, and idiomatic version. The three versions contained the same content (conversation between two female college students). The formal version used polite English which non-native speakers usually learn at school. The natural version used colloquialisms commonly spoken by college students. The idiomatic version consisted of idioms shared by college friends.

The common theme of the three video clips was college students talking about a plan for shopping after class. It was chosen because it is often discussed among female college 
friends. In other words, the message was natural and familiar.

The second independent variable, the status, was divided into two treatment levels: native speakers of English and non-native speakers of English. Both treatment levels were restricted to college students because the study needed to be focused on a specific speech community which shares idioms to avoid overgeneralizing the results.

The seventeen dependent variables (comprehension, ability, informality, efficiency, flexibility, smoothness, spontaneity, closeness, female teen-agers, female college students, middle-aged women, female senior citizens, home, church, work, classroom, bar) were measured in terms of a paper and pencil questionnaire, which will be discussed in the questionnaire construction section.

Other related dependent variables and open-ended questions were included in the questionnaire. They were not analyzed due to the fact that they were beyond the scope of this study and for future research. Questionnaire Construction and Face Validity Survey research was conducted to elicit responses from college students who are native and non-native speakers of English. A measurement instrument was constructed carefully after consultations with communication scholars and fellow graduate students to insure face validity. Also, 17 natives and 3 non-natives enrolled in a communication class 
participated in the pretest and had discussion with the researcher afterwards. The discussion focused on the wording of the items to assure that the questionnaire was comprehensible and natural to the subjects. The discussion with them was very helpful because the researcher was made to realize that some technical terms used in the original questionnaire served to confuse the respondents. Their comments and suggestions were incorporated to revise the questionnaire. Particularly, bipolar adjectives used in Knapp's measurement of the developmental view of interpersonal relationships were paraphrased. For example, "The conversation is stylized," was changed to "The conversation is formal," and "The message exchange is difficult," was changed to "The message exchange is energy consuming." Also, students were confused by the meaning of "speech style." The questionnaire, therefore, begins with a definition of speech style: "speech style means the words and phrases used by the two actresses."

Questionnaire Items

This questionnaire consists of four parts. The first part elicits demographic information about college students who are native and non-native speakers of English. The second part collects data regarding their idiom comprehension. The third part measures their perceived interpersonal relationship. The fourth part explores the 
subjects' use of idioms and their intercultural experience (see Appendix B) .

Demographics. Native speakers were asked to identify their age, major, and ethnic background. Non-native speakers were asked to identify their age, major, native language, ethnic background, the length of stay in America, and years of studying English. In addition, non-native speakers were asked to describe how they were taught English, and problems they had in communicating with Americans.

Idiom comprehension. The subjects were asked if they understood the conversation. They were also asked to paraphrase idiomatic expressions.

Perceived interperscnal relationship. Knapp's measurement scale was used to elicit native and non-native speakers' perceptions regarding the interpersonal relationship. Due to the nature of video clips designed by the researcher, four irrelevant adjectives (narrow, broad, public, personal) were deleted. Besides paraphrasing originally used adjectives, some statements were added by the researcher herself to measure subjects' perceptions regarding speech styles. Each of the statements was followed by a seven-point Likert-type scale, seeking the subjects' response from "strongly disagree" to "strongly agree." Subjects were also asked to identify who uses the speech style used in the video clip. 
Use of idioms. In this segment, subjects were asked to respond about their ability to produce the speech style, their likelihood of using the speech style with friends, and their preference in engaging in the conversation. Each statement was measured by a seven-point Likert-scale ranging from "strongly disagree" to "strongly agree." Subjects were also asked whether or not they felt comfortable in using idiomatic expressions at locations such as home, church, work, classroom, and bar.

Intercultural experience. Items on the questionnaire asked subjects to respond to their intercultural experiences and their choice of the speech style in intercultural situations. Subjects were also asked to describe their intercultural casual friends.

Design

The two independent variables produce a $2 \times 3$ factorial design. Table 2.1 shows six experimental conditions.

\begin{tabular}{|c|c|c|}
\hline $\begin{array}{c}\text { Cell one } \\
\text { native } \mathrm{x} \text { formal }\end{array}$ & $\begin{array}{c}\text { Cell Two } \\
\text { native } \mathrm{x} \text { natural }\end{array}$ & $\begin{array}{c}\text { Cell Three } \\
\text { native } \mathrm{x} \text { idiom }\end{array}$ \\
\hline Cell Four & cell Five & cell Six \\
non-native $\mathrm{x}$ formal & non-native $\mathrm{x}$ natural & non-native $\mathrm{x}$ idiom \\
\hline
\end{tabular}

Table 2.1 Experimental conditions.

Subjects

To measure responses to the three video clips, 206 undergraduate students who were enrolled in communication 
classes at San Jose State University were shown the video clips and asked to complete the questionnaire (93 native speakers, 113 non-native speakers). Subjects who did not respond appropriately were eliminated from analyses. Also, non-native speakers who have stayed in the United States for over 15 years were deleted from the data. In total, 168 subjects remained for data analyses, resulting in 28 cases in each condition.

Cell one had 14 males and 14 females. Cell two had 5 males and 23 females. Cell three had 9 males and 19 females. The mean age of native speakers was 25.5 . There were 42 (50\%) Whites, 9 (10.8\%) Asians, 5 (6\%) African-Americans, 5 (6\%) Hispanics and 23 (27.2\%) other ethnic backgrounds among native speakers.

Cell four had 14 males and 14 females. Cell five had 14 males and 14 females. Cell six had 15 males and 13 females. The mean age of non-native speakers was 22.5. There were 63 (75.1\%) Asians, 4 (4.8\%) Whites, 2 (2.4\%) Hispanics and 15 (17.7\%) other ethnic backgrounds among non-native speakers. There were 30 (35.8\%) Chinese, 25 (29.8\%) Vietnamese, 4 (4.8\%) Tagalog, 3 (3.6\%) Arabic, 3 (3.6\%) Burmese, 3 (3.6\%) Cambodian, 2 (2.4\%) Spanish and 14 (16.8\%) other language speaking students. The mean length of their stay in the United States was roughly 7 years. The mean length of their English study was approaching 10 years. 
Procedure

The researcher arranged to collect the data during regularly scheduled meetings of the participants. Before the questionnaire survey, the researcher explained that the purpose of the study was to explore the link between the use of idioms and intercultural relationship, provided instructions for responding to the scale items, and distributed the questionnaire. Subjects were assigned to one of the conditions according to their native language. They were exposed to the message by video clips. Each session lasted approximately 30 minutes. At the end of each session, the researcher collected the questionnaires and placed them in separate containers according to their language status and the version of the video clips. The researcher thanked the subjects for their participation.

The statistical analyses of the data are presented in the following chapter. 
CHAPTER III

Results

The data were analyzed using an SPSS/PC+ program (version 4.0). First, 2-way analyses of variance were performed to explore the main effects and interaction effects (stimulus by status) on four sets of dependent variables (comprehension, ability, perceived interpersonal relationships, generation identification). Second, one-way analyses of variance and t-tests were further conducted to refine our understanding of interaction effects generated from two-way ANOVA. Then, t-tests were conducted on items related to the use of idioms of both native and non-native speakers of English.

\section{Research Findings}

The results of two-way ANOVA, one-way ANOVA, and t-tests are given in Tables 3.1 to 3.3 . Results that are boldfaced reach the .05 significance and those underlined reach the .01 significance. The abbreviation of 12 dependent variables is provided in Table 3.1-1.

Two-Way Analyses of Variance

The two independent variables were speaking status (native vs. non-native) and stimulus (formal, natural, and idiomatic versions). Two-way ANOVA $(2 \times 3)$ were conducted on 12 dependent variables to obtain main and interaction effects between status and stimulus. Results are summarized in Table 3.1 . 


\begin{tabular}{|c|c|c|c|c|c|c|c|c|c|c|c|c|}
\hline & Comp & $\mathrm{AbI}$ & Rel1 & Rel2 & Rel3 & Rel4 & Rel5 & Rel6 & Gen1 & Gen2 & Gen3 & Gen4 \\
\hline Main Effects & .009 & $\leq .001$ & $\leq .001$ & $\underline{010}$ & $\leq, 001$ & .007 & $\leq .001$ & $\leq .001$ & $\leq, 001$ & .048 & $\leq, 001$ & $\leq, 001$ \\
\hline Stimulus & .151 & .004 & $\leq .001$ & .018 & $\leq .001$ & .008 & $\leq .001$ & $\leq .001$ & $\leq .001$ & . 030 & $\leq .001$ & $\leq .001$ \\
\hline Status & .005 & $\leq .001$ & .185 & .040 & .055 & 879 & .034 & .023 & .113 & .344 & .005 & .006 \\
\hline Interactions & .005 & .129 & $\leq .001$ & $\leq .001$ & .006 & .099 & .044 & .006 & .032 & .101 & .148 & 011 \\
\hline Explained & .001 & $\leq .001$ & $\leq .001$ & $\leq, 001$ & $\leq .001$ & $\underline{005}$ & $\leq .001$ & $\leq .0001$ & $\leq, 001$ & .030 & $\leq, 001$ & $\leq .001$ \\
\hline
\end{tabular}

Table 3.1 Main and interaction effects between status and stimulus.

\begin{tabular}{|c|c|}
\hline Comp & Comprehension \\
Abl & Ability \\
Rel1 & Informality \\
Rel2 & Efficiency \\
Rel3 & Flexibility \\
Rel4 & Smoothness \\
Re15 & Spontaneity \\
Rel6 & Closeness \\
Gen1 & Female teen-agers \\
Gen2 & Female college students \\
Gen3 & Middle-aged women \\
Gen4 & Female senior citizens \\
\hline
\end{tabular}

Table 3.1-1 Dependent variables.

Status $(F(1,160)=8.031, D=.005)$ rather than stimulus showed significant main effect on comprehension. Two-way interaction effect was also found for comprehension $(F(2,160)=5.559, \underline{p}=.005)$. See Table C.1.1 in Appendix C.

A significant interaction for ability was not obtained $(F(2,160)=2.077, \underline{D}=.129)$ even though there were significant main effects for both stimulus and status $(\underline{p}=.004, \underline{p}<.001)$ (see Table C.1.2).

In terms of perceived relationships, informality $(F(2,160)=10.287, \underline{Q}<.001)$, efficiency $(F(2,160)=8.636$, $\underline{Q}<.001)$, flexibility $(F(2,160)=5.203, \underline{Q}=.006)$, and spontaneity $(F(2,161)=3.186, D=.044)$ reached significant 
interaction effects. Both stimulus and status contributed to the result except informality. Informality showed the significance in stimulus $(\mathrm{p}<.001)$, but not in status $(\underline{D}=.185)$. See Tables C.1.3 to C.1.8.

Regarding generation identifications, female teen-agers $(F(2,161)=3.517, D=.032)$ and female senior citizens $(F(2,161)=4.685, p=.011)$ obtained significant interaction effects. There was a significance in female teen-agers in stimulus $(\mathrm{Q}<.001)$ but not in status $(\mathrm{D}=.113)$. Both stimulus and status contributed to female senior citizens $(\underline{p}<.001$, $\mathrm{D}=.006)$. See Tables C.1.9 to C.1.12.

One-Way Analyses of Variance

One-way ANOVA were conducted to further explore interaction effects obtained in the preceding two-way ANOVA. Status was held constant in this section. The following results reflect native and non-native speakers' responses across three stimulus conditions respectively. Schematic results are given in Table 3.2 .

\begin{tabular}{|c|c|c|c|c|c|c|c|c|c|c|c|c|c|}
\hline & & Comp & $\mathrm{Abl}$ & Rel1 & Rel2 & Rel3 & Rel4 & Rel5 & Rel6 & Gen1 & Gen2 & Gen3 & Gen4 \\
\hline \multirow[t]{4}{*}{ Native } & Formal & 6.18 & 6.04 & 3.71 & 2.50 & 2.82 & 2.57 & 3.57 & 4.11 & 3.57 & 3.57 & 3.39 & 3.11 \\
\hline & Natural & 6.07 & 6.11 & 6.25 & 4.57 & 4.82 & 4.50 & 5.54 & 5.46 & 5.93 & 4.96 & 2.14 & 1.18 \\
\hline & Idiomatic & 6.46 & 5.64 & 6.89 & 4.07 & 5.32 & 3.64 & 5.79 & 5.50 & 6.04 & 4.64 & 1.89 & 1.18 \\
\hline & Sig. of $F$ & .493 & .442 & $\leq .001$ & $\leq .001$ & $\leq, 001$ & $\leq .001$ & $\leq .001$ & .001 & $\leq .001$ & .004 & $\leq, 001$ & $\leq .001$ \\
\hline Non- & Formal & 6.23 & 5.46 & 5.11 & 4.37 & 3.41 & 3.48 & 3.96 & 3.89 & 4.07 & 4.15 & 3.52 & 2.93 \\
\hline \multirow[t]{3}{*}{ Native } & Natural & 5.82 & 4.71 & 5.18 & 3.79 & 4.14 & 3.96 & 4.54 & 4.04 & 5.25 & 4.43 & 3.39 & 2.75 \\
\hline & Idiomatic & 4.93 & 3.93 & 5.48 & 4.44 & 4.00 & 3.41 & 4.74 & 5.37 & 4.89 & 3.89 & 2.59 & 1.71 \\
\hline & Sig. of $F$ & .003 & .002 & .764 & .319 & .216 & .486 & .306 & .010 & .055 & .543 & .083 & .023 \\
\hline
\end{tabular}

Table 3.2 Native and non-native speakers' responses across stimuli. 
Native speakers

There was no significance in comprehension $(F(2,81)=.714, D=.493)$ and ability $(F(2,81)=.824, D=.442)$ for stimulus. Stated differently, native speakers comprehended each conversation equally well. Also, they were able to use each speech style equally well.

All the perceived interpersonal relationships and generation identification of the speech styles reached the significance. Native speakers were able to differentiate perceived interpersonal relationships and who used the speech style in each conversation. Mean scores of efficiency (formal=2.50, natural=4.57, idiomatic $=4.07$ ) and smoothness ( formal $=2.57$, natural $=4.50$, idiomatic $=3.64$ ) showed irregularity in the perceived interpersonal relationships (see Tables C.2.1 to C.2.10). Other than that, the mean scores of idiomatic version were the highest and those of formal version were the lowest.

Non-native speakers

There was significance in comprehension and ability for stimulus. Stated differently, non-native speakers comprehended the formal version of the conversation most, the natural version of the conversation next and the idiomatic version of the conversation least. Also, they were not able to use each speech style equally well (see Tables C.3.1 and C.3.2) . 
Only closeness reached the significance in the perceived interpersonal relationships. Furthermore, the only age group which reached the significance was female senior citizens (see Tables C.3.3 and C.3.4). Non-native speakers were not able to differentiate perceived interpersonal relationships and who used the speech style in each conversation as accurately as native speakers were.

Significance of Mean Differences for Native and Non-native Speakers

T-tests were conducted with native and non-native speakers of English to determine if the means for comprehension, ability, perceived interpersonal relationships and generation identification were significantly different across three speech styles to supplement the findings from two-way ANOVA. Stimulus was held constant in the following analyses. Schematic results are presented in Table 3.3.

\begin{tabular}{|c|c|c|c|c|c|c|c|c|c|c|c|c|c|}
\hline & & Comp & $A b \mid$ & Rel1 & Rel2 & Rel3 & Rel4 & Rel5 & Rel6 & Gen1 & Gen2 & Gen3 & Gen4 \\
\hline \multirow[t]{3}{*}{ Formal } & Native & 6.18 & 6.04 & 3.71 & 250 & 2.82 & 2.57 & 3.57 & 4.10 & 357 & 3.57 & 3.39 & 3.11 \\
\hline & Non-native & 629 & 5.54 & 5.14 & 4.36 & 3.36 & 3.43 & 3.96 & 3.78 & 4.11 & 4.11 & 3.50 & 2.93 \\
\hline & $\underline{p}$ & .771 & .187 & .017 & $\leq .001$ & 216 & .081 & .453 & .548 & .392 & .302 & 829 & .740 \\
\hline \multirow[t]{3}{*}{ Natural } & Native & 6.07 & 6.11 & 625 & 4.57 & 4.82 & 4.50 & 5.54 & 5.46 & 5.93 & 4.96 & 2.14 & 1.18 \\
\hline & Non-native & 5.82 & 4.71 & 5.18 & 3.79 & 4.14 & 3.96 & 4.54 & 4.04 & 525 & 4.43 & 3.39 & 2.75 \\
\hline & $\underline{\mathrm{g}}$ & .549 & $\underline{\underline{001}}$ & .021 & .099 & .096 & 261 & .029 & .002 & .056 & 205 & $\underline{.002}$ & $\leq .00 t$ \\
\hline \multirow[t]{3}{*}{ Idiom } & Native & 6.46 & 5.64 & 6.89 & 4.07 & 5.32 & 3.64 & 5.78 & 5.50 & 6.03 & 4.64 & 1.89 & 1.18 \\
\hline & Non-native & 4.93 & 3.92 & 5.50 & 4.46 & 4.00 & 335 & 4.67 & 5.32 & 489 & 3.80 & 2.53 & 1.71 \\
\hline & $\underline{\mathrm{p}}$ & $\leq .001$ & $\leq .001$ & $\leq .001$ & .386 & .004 & .566 & .018 & .670 & .002 & .079 & .059 & .066 \\
\hline
\end{tabular}

Table 3.3 Significance of mean differences of dependent variables for native and non-native speakers. 
Formal version

There was no significant difference between native and non-native speakers (6.1786 vs. $6.2857, \mathrm{p}=.771$ ) regarding the comprehension of the formal version of conversation (see Table C.4.1).

There was no significant difference between native and non-native speakers (6.0357 vs. $5.5357, \mathrm{p}=.187$ ) regarding the ability to use the formal speech style (see Table C.4.2).

In terms of the perceived interpersonal relationship in the formal speech style, informality (3.7143 vs. 5.1429, $\mathrm{Q}=.017)$ and efficiency $(2.5000$ vs. $4.3571, \mathrm{D}<.001)$ showed significant differences between native and non-native speakers (see Tables C.4.3 to C.4.8). Non-native speakers thought the formal speech style more informal than native speakers did. Non-native speakers thought the message was exchanged more efficiently than native speakers did.

There was no significant difference between native and non-native speakers' responses regarding the generation identification of the speech style used in the formal conversation (see Tables C.4.9 to C.4.12).

Natural version

There was no significant difference between native and non-native speakers (6.0714 vs. $5.8214, \mathrm{Q}=.549)$ over the comprehension of the natural version of the conversation (see Table C.5.1). 
In terms of the ability to use the natural speech style, there was a significant difference between native and nonnative speakers (6.1071 vs. $4.7143, \underline{p}=.001$ ) (see Table C.5.2). Non-native speakers were less able to use the natural speech style than native speakers were.

Regarding the perceived interpersonal relationships in the natural speech style, informality (6.2500 vs. 5.1786, $\underline{\mathrm{p}}=.021)$, spontaneity (5.5357 vs. $4.5357, \mathrm{p}=.029)$ and closeness ( 5.4643 vs. $4.0357, \underline{p}=.002$ ) showed significant differences between native and non-native speakers (see Tables C.5.3 to C.5.8). Native speakers thought the interpersonal relationship was more informal, the message was exchanged more spontaneously and the relationship of the two women was closer than non-native speakers did.

Middle-aged women (2.1429 vs. $3.3929, \underline{p}=.002)$ and female senior citizens (1.1786 vs. $2.7500, \underline{D<}<.001)$ showed significant differences between native and non-native speakers' responses in the generation identification of the speech style used in the natural conversation (see Tables C.5.9 to (.5.12). Non-native speakers did not identify the generation that used the speech style as accurately as native speakers did.

Idiomatic version

There was a significant difference between native and non-native speakers $(6.4643$ vs. $4.9286, \mathrm{p}<.001)$ regarding the comprehension of the idiomatic version of conversation (see 
Table C.6.1). Non-native speakers did not comprehend the idiomatic conversation as well as native speakers did.

There was a significant difference between native and non-native speakers (5.6429 vs. $3.9286, \underline{\mathrm{p}}<.001)$ in terms of the ability of using the idiomatic speech style (see Table C.6.2). Non-native speakers were less able to use the idiomatic speech style than native speakers were.

Regarding the perceived interpersonal relationship in the idiomatic speech style, informality (6.8929 vs. 5.5000, $\underline{p}<.001)$, flexibility (5.3214 vs. $4.000, \underline{p}=.004)$ and spontaneity (5.7857 vs. $4.6786, \mathrm{Q}=.014)$ showed significant differences between native and non-native speakers (see Tables C.6.3 to C.6.8). Native speakers thought the interpersonal relationship was more informal, the message was exchanged in more flexible and spontaneous ways than nonnative speakers did.

Female teen-agers $(6.0357$ vs. $4.8929, \underline{p}=.002)$ showed a significant difference between native and non-native speakers' responses in the generation identification of the speech style (see Tables C.6.9 to C.6.12). Non-native speakers were not able to discriminate the generation that used the idiomatic speech style as well as native speakers were. 
Mean Differences for Native and Non-native Speakers' Idiom

Use

To explore Research Question 5, t-tests were conducted with native and non-native speakers of English to determine if there were significant differences in using idioms comfortably in the selected locations: at home, in church, at work, in the classroom, in the bar (see Table 3.4).

\begin{tabular}{|c|c|c|c|c|c|}
\hline & Home & Church & Work & Classroom & Bar \\
\hline Native & 5.81 & 3.20 & 4.11 & 4.49 & 5.54 \\
\hline Non-native & 5.51 & 4.94 & 5.30 & 4.88 & 5.15 \\
\hline$\underline{Q}$ & 267 & .001 & $\leq .001$ & .129 & .185 \\
\hline
\end{tabular}

Table 3.4 Results of t-tests for comfortableness in using idioms in selected locations.

Significant differences were observed between native and non-native speakers' comfortableness in using idioms in church (3.2035 vs. $4.9375, \mathrm{p}=.001)$, and at work $(4.1084$ vs. $5.3043, \underline{\mathrm{p}}<.001$ ) (see Tables C.7.1 and C.7.2). Non-native speakers were not able to use idioms in some locations. Native speakers' mean scores varied according to each location. Non-native speakers' mean scores, however, stayed near 5.000 in every location.

Research Questions posed in Chapter I and implications of this study will be discussed in chapter IV. 
CHAPTER IV

Discussion

This study first explained non-native speakers'

difficulty with idiom comprehension from a psycholinguistic perspective. Then it pointed out the neglect of the interpersonal relationship indicated by iaioms in the ESI literature. It also took the position that one of the barriers to building a close intercultural relationship between native and non-native speakers of English might lie in the use of idioms. Thus, three video clips were created and shown to both native and non-native college students to explore the link between the use of idioms and the intercultural relationship. Specifically, it attempted to answer research questions posed at the end of Chapter $I$. Research Question 1: Comprehension

Research Question 1 asked if non-native speakers comprehended the conversation less than native speakers regarding each speech style. This research question was confirmed as predicted from the literature review. Findings in Chapter III demonstrated that native speakers had no trouble understanding each conversation. Because of their status as native speakers, the result was no surprise. Nonrative speakers comprehended the formal version very well as native speakers did. They had minor trouble understanding the natural version compared to native speakers' level. Nonnative speakers comprehended the idiomatic version very 
poorly. This was explained through the status aid the interaction between status and stimulus together. The largest difference in native and non-native speakers' comprehension was observed in the idiomatic condition. This evidences the potential for communication breakdowns between native and non-native speakers over the use of idioms. Nonnative speakers' relative lack of idiom comprehension potentially excludes the prospect of close intercultural relationships. Non-native speakers need to familiarize themselves with idiomatic speech style.

\section{Research Question 2: Ability}

Research Question 2 asked if non-native speakers were able to use each speech style less than native speakers. This research question was confirmed as predicted. The findings in the Chapter III demonstrated that native speakers were able to use each speech style equally well. It is understandable because of their status. Non-native speakers' ability to use each speech style varied. They were able to use the formal speech style best, the natural one next, and the idiom one the least. Non-native speakers reached native speakers' level only in formal speech style use. Comparing native and non-native speakers' ability to use the speech styles, there was a big difference in the natural version. There was an even greater difference in the ability to use idiomatic speech style. As with the results of Research Question 1, inability to use idiomatic speech style might 
block conversations between native and non-native speakers of English. In addition, these differences were greater than those seen in comprehension. It suggests ESL teaching needs to put more effort on improving non-native speakers' ability to use natural and idiomatic speech styles to reduce communication breakdown with native speakers.

Research Question 3: Perceived Interpersonal Relationship

Research Question 3 asked if non-native speakers perceived interpersonal relationships differently from native speakers. This research question was also confirmed partially. T-tests indicated that non-native speakers perceived interpersonal relationships differently in some areas from Knapp's measurement items. In the formal version, mean score of efficiency (2.5000 vs. 4.3571, $\mathrm{p}<.001)$ showed a significant difference. Stated differently, even though nonnative speakers comprehend and use formal speech style as well as native speakers, their perception regarding interpersonal relationships is not the same as that of native speakers. In terms of the natural version, non-native speakers had different perceptions on informality, spontaneity, and closeness. Regarding the idiomatic version, informality, efficiency, and spontaneity showed significant differences in native and non-native speakers' perceptions. These are areas in which non-native speakers need to be aware of the difference and try to minimize the discrepancy between their perceptions and those commonly shared by native 
speakers. Two-way ANOVA found significant interaction effects produced by stimulus and status, especially on efficiency, flexibility, and spontaneity. Status accounted for differences in these areas. The findings suggest that as non-native speakers and native speakers begin to share relational understandings, their communicative competence will grow.

The findings from ANOVA demonstrated that native speakers could differentiate perceived relationships of each speech style. The standard deviation was small on each version. In other words, they had reached the consensus regarding perceived relationships in each version. Mean scores of efficiency (formal=3.71, natural=4.50, idiomatic=4.07) and smoothness (formal=2.57, natural=4.50, idiomatic $=3.64$ ) did not follow the predicted trend that idiomatic version would score highest, natural one second, and formal one lowest. This fact suggests that idiom use does not automatically mean a close relationship. Native speakers considered the two actresses' nonverbal cues and the content even though they were instructed to concentrate on the speech style. This finding, however, is interesting. It suggests that idioms indicate closeness but that there is no right or wrong interpretation of interpersonal relationships indicated by the use of idioms. Nonverbal cues and the content of the conversation may influence the perception. One thing, however, seems to be certain; that is, native 
speakers share similar perception regarding each interpersonal relationship.

The ANOVA showed that non-native speakers were not able to discriminate perceived relationships in each speecn style. They were able to distinguish relationships only on the degree of closeness. Given the fact that they failed to differentiate other areas and their failure to comprehend the idiomatic version, they might have reacted to nonverbal cues, including the tone of voice, on closeness. The standard deviation was large and their responses did not have the same trend as native speakers. Stated differently, non-native speakers sporadically share the relational interpretation with native speakers. In areas that are not shared 18 out of 18), relational misperception and action discoordination may occur. If non-native speakers are aware of relational differences indicated by speech styles and can cultivate similar perceptions shared by native speakers, they will be more likely to improve their communicative competence in intercultural settings.

Research Question 4: Generation Identification

Research Question 4 asked if non-native speakers identified what age group of people uses each speech style differently from native speakers. The results of t-tests on natural version showed significant difference in middle-aged women and female senior citizens. Though shy of significance $(\mathrm{D}=.056)$, female teen-agers category's result suggested 
difference in the perception. In terms of the idiomatic version, female teen-agers reached significance ( $p=.002)$. Female college students, middle-aged women, and female senior citizens did not reach significance but results were in the predicted direction. Two-way ANOVA showed stimulus and status interactions in female senior citizens. Also, status contributed tremendously to the generation identification of middle-aged women. What these findings mean is that nonnative speakers are not as good as native speakers in identifying and differentiating the speech styles used by people in different age groups. Non-native speakers might have very limited contacts with people in different age groups. Although they have learned formal English at school and they can talk with American college students on campus, it might be rare for non-native speakers to converse with middle-aged people or senior citizens, which suggests that they are not able to notice the different speech style according to the age group. Non-native speakers, therefore, will be able to increase their intercultural communicative competence regarding relational differences by being more sensitive to who uses the particular speech style.

Native speakers were able to distinguish each speech style clearly according to each age group based on ANOVA results. They reached consensus among themselves in terms of generation identification. 
The results from the ANOVA demonstrated that non-native speakers were able to identify only female senior citizens distinctly regarding each speech style $(\underline{p}=.023)$. They had trouble identifying and differentiating the female college students group according to their speech style $(\underline{p}=.543)$. The mean score of the formal version (4.15) was higher than that of the idiomatic version (3.89) in this age group. This shows a different trend from that of the native speakers. There are some explanations for this finding. First, nonnative speakers have rare or limited contacts with age groups other than college students in daily encounters. Therefore, they may not be aware of the difference in speech styles according to age groups. Second, they learned about polite and impolite speech styles and male and female speech styles at school, but age differences in speech styles were not emphasized. It will be helpful for non-native speakers to equip themselves with different age groups' speech styles to bridge the gap of relational understanding.

Research Question 5: Use of Idioms

Research Question 5 asked if non-native speakers felt differently from native speakers in using idioms. The findings from t-tests demonstrated that there were significant differences in how comfortable native and nonnative speakers felt using idioms in church and at work. Native speakers' mean scores vary according to locations while non-native speakers' scores fall around 5.000 in each 
location. This suggests that non-native speakers violate the social norm shared by native speakers unconsciously by using idioms where native speakers feel uncomfortable using them. ESL teachers need to teach idioms to non-native speakers along with where and with whom they can use those idioms.

Summary

Several important findings emerged from this study. First, non-native speakers need to learn more idions because they showed significantly lower comprehension than native speakers in this area. In addition, they are not able to use both idiomatic and natural speech styles as well as native speakers. The difference in ability to use natural and idiomatic speech styles was greater than that of comprehension of conversations between native and non-native speakers. It suggests that ESL teaching needs to devote more efforts to improving non-native speakers' ability to use natural and idiomatic speech styles in order to minimize communication breakdown with native speakers.

Second, non-native speakers need to be reminded that the idiom use does not necessarily mean a close interpersonal relationship. Native speakers consider the content of a conversation and nonverbal cues used as well as idioms when determining relationships. This study did not explore these additional factors. Future research needs to address the link between the relational perception and thematic content and/or nonverbal clies. 
Third, native and non-native speakers need to bridge the gap in their relational understanding. Native speakers share more or less the same perception of an interpersonal relationship while non-native speakers do not. Non-native speakers had different relational understandings regarding two out of six items in Knapp's measurement scale even in the formal version. Non-native speakers should start working on areas in Knapp's measurement items wherever they provide different relational perceptions from native speakers. Native speakers, on the other hand, need to be sensitive to non-native speakers' problems in identifying interpersonal relations. By doing so, both parties will be able to improve their communicative competence dialogically in intercultural encounters.

Fourth, now that ESL teaching has succeeded well its job in teaching the formal speech style, it is time to move on to focusing on natural and idiomatic speech styles. ESL teachers need to emphasize idiom teaching more, including where and with whom to use idioms. Even though non-native speakers who responded to the idiom use at locations such as home, church, work, classroom, and bar, their degree of feeling comfortable using them were different from that of native speakers'. In other words, they are not familiar with native speakers' norms regarding the use of idioms. In addition, they are not able to discriminate speech styles as clearly as native speakers. 
Recommendations to ESL

There are four specific recommendations to ESL in terms of teaching idioms. First, we should teach formal English to non-native speakers. Then we should expose them to idiomatic expressions so that they lose some of the stiffness of formal communication so that they can better fit in the culture. This method will give non-native speakers a natural transition from a formal to an idiomatic speech style. second, whenever teachers use idioms in class, they should repeat the expressions and paraphrase them in a formal manner. In this way, teachers can speak naturally by using idioms and make sure non-native speakers understand their meanings properly.

Third, we can make updated conversation videos with idioms for students. There is a time lag between writing a textbook and using it in two aspects. First, it generates outdated idioms in the textbook. Second, due to their generation gap, a textbook writer is familiar with certain idioms while a teacher is not. Keeping videos updated, therefore, is helpful for supplementing these problems.

Fourth, we can encourage non-native speakers to ask questions whenever they encounter unfamiliar idioms. They tend to hesitate to stop conversations and ask questions. As suggested by Lee (1992), setting up a ground rule which encourages non-native speakers to ask questions freely and 
requests native speakers to provide explanations will be effective for teaching and learning idioms.

Implication to Communication Research

Three implications to intercultural communication research will conclude this study. First, problems with idiom comprehension may be applied to native speakers, too. Generation gaps among native speakers generate potential communication breakdowns with idiom comprehension. The study of idioms can be a way of approaching communication with people from different age groups.

Second, African-American, Latino, and other minority students experience similar problems as non-native speakers face regarding their language use. They often do not fit in the language norm privileged in academic settings, and face more barriers to academic success. We can look at their difficulties at school from the viewpoint of intercultural communication. We may investigate ways in which smooth transitions may be created to bridge the gap between language use at home and that privileged at school.

Finally, the results would be more dramatic if the study examined non-native speakers who had never been to the United states. The researcher hopes that her research will contribute to opening up new doors for non-native speakers who are in the United States as well as overseas to have closer and happier intercultural relationships with native speakers of English through the use of and understanding of 
idioms. The use of idioms will give spice and liveliness to conversations and bring fun relationships between them. 
REFERENCES 
REFERENCES

Abkarian,G.G., Jones,A., \& West,G. (1990). Enhancing children's communication skills: Idioms 'Eill the bill'. Child Language Teaching and Therapy, 6, 246-254.

Alexander,R.J. (1984). Fixed expressions in English: reference books and the teacher. ELT Journal, 38, 127134 .

Alexander,R.J. (1985). Phraseological and pragmatic deficits in advanced learners of. English: Problems of vocabulary learning? Die Neueren úprachen, 84, 613-621.

Austin, P., \& Kuiper,K. (1998). Constraints on coordinated idioms. Te Reo, 31, 3-17.

Batt,K. (1988). ESL curriculum quide: Materials and methods for teaching English as a second language to adults. Free Library of Philadelphia: Philadelphia.

Bobrow, S., \& Bell,S. (1973). On catching on to idiomatic expressions. Memory and Cognition, 1, 343-346.

Cacciari,C., \& Levorato,M.C. (1989). How children understand idioms in discourse. Journal of Child Language, 16, $387-405$.

Cacciari,C., \& Tabossi,P. (1988). The comprehension of idioms. Journal of Memory and Lanquage, 27, 668-683.

Celona,J.M. (1983). What does "wicked good" really mean?: Students talk about their ESL problems. MEXTESOL Journal, I, 42-55.

Cohen,G.L. (1973-1974). Substitution as a source of idiomaticity. Missouri Academy of Science, 7-8, 228234 .

Coleman,D.W. (1984). Idiomaticity and the autonomy of syntax in stratificational grammar. Southwest Journal of Linguistics, $7,26-46$.

Coulmas,F. (1979). Idiomaticity as a problem of pragmatics. In H.Parret, M.Ibisa, \& J.Verschueren(Eds.), Possibilities and limitations of pragmatics (pp.139151). Amsterdam: Benjamins. 
Cutler,A. (1982). Idioms: The colder the older. Linguistic Inquiry, 13, 317-320.

DascaI,M. (1987). Defending literal meaning. Coonitive Science, 11, 259-281.

Dascal,M. (1989). On the role of context and literal meaning in understanding. Cognitive Science, 13, 253-257.

Drysdale,P. (1981). The idiocy of idioms: A problem in lexicography. CJL RCL, 26, 113-117.

Fussell,S.R., \& Kraus,R.M. (1989). Understanding friends and strangers: The effects of audience design on message comprehension. European Journal of Social Psycholocy, 19 , 509-525.

Garfinkel,H. (1969). Remarks on ethnomethodology. In J.Gumperz \& D. Hymes (Eds.), Directions in sociolinguistics. New York: Holt, Rinehart and Winston.

Gibbs,Jr.R.W. (1980). Spilling the beans on understanding and memory for idioms in conversation. Memory \& Cognition, 8, 149-156.

Gibbs, Jr.R.W. (1984). Literal meaning and psychological theory. Cognitive Science, 8, 275-304.

Gibbs, Jr.R.W. (1985). On the process of understanding idioms. Journal of Psycholinguistic Research, 14, 465-472.

Gibbs, Jr.R.W. (1986). Skating on thin ice: Literal meaning and understanding idioms in conversation. Discourse Processes, $9,17-30$.

Gibbs,Jr.R.W. (1987). Linguistic factors in children's understanding of idioms. Journal of Child Language, $14,569-586$.

Gibbs, Jr.R.W. (1989). Understanding and literal meaning. Cognitive Science, 13, 243-251.

Gibbs,Jr.R.W., \& Gonzales,G.P. (1985). Syntactic frozenness in processing and remembering idioms. Cognition, 20, 243-259.

Gibbs, Jr.R.W., \& Nagaoka,A. (1985). Getting the hang of American slang: Studying of understanding and 
remembering slang metaphors. Language and Speech, 17, 177-194.

Gibbs,Jr.R.W., \& Nayak, N.P. (1989). Psycholinguistic studies on the syntactic behavior of idioms. Cognitive Psychology, 21, 100-138.

Gibbs,Jr.R.W., Nayak, N.P., Bolton, J., \& Keppel,M.E. (1989) . Speakers' assumptions about the lexical flexibility of idioms. Memory \& Cognition, 17, 58-68.

Gibbs, Jr.R.W., Nayak, N.P., \& Cutting, C. (1989). How to kick the bucket and not decompose: Analyzability and idiom processing. Journal of Memory and Lanquage, 28, 576593.

Gibbs, Jr.R.W., \& O'Brien. (1990). Idioms and mental imagery: The metaphorical motivation for idiomatic meaning. cognition, $36,35-68$.

Glaser,R. (1988). The grading of idiomaticity as a presupposition for a taxonomy of idioms. In W.Hullen, \& K.Schulze(Eds.), Understanding the lexicon: Meaning, sense and world knowledge in lexical semantics (pp.264279). Tubingen: Niemeyer.

Glass, A.L. (1983). The comprehension of idioms. Journal of Psycholinguistic Research, 12, 429-442.

Gumperz,J.J. (1971). Language in social groups. Stanford, California: Stanford University Press.

Hietsch,0. (1980). The mirthless world of the bilingual dictionary: A critical look at two German-English examples, and a glossary. Linquistica, 20, 183-218.

Hopper,R., Knapp,M.L., \& Scott,L. (1981). Couple's personal idioms: Exploring intimate talk. Journal of communication, 31, 23-33.

Irujo,s. (1984). The effects of transfer on acquisition of idioms in a second language. (Doctoral dissertation, Boston University, 1984). Dissertation Abstracts International, 45, 833A.

Irujo,s. (1986). Don't put your leg in your mouth: Transfer in the acquisition of idioms in a second language. TESOL Quarterly, 20, 287-304. 
Kemper, S. (1989). Priming the comprehension of metaphors. Metaphor and Symbolic Activity, 4, 1-17.

Klopf,D.W. (1991). Intercultural encounters (2nd Ed.). Englewood, Colorado: Morton.

Knapp,M.L. (1984). Interpersonal communication and human relationships. Massachusetts: Allyn and Bacon, Inc.

Kumaravadivelu, B. (1988). Communications strategies and psychological processes underlying lexical simplification. IRAL, 26, 309-319.

Lee,W.S. (1992). Missing the boat: The centrality of idioms in intercultural communication. Manuscript submitted for publication.

Lynch,A.J. (1988). Speaking up or talking down: Foreign learners' reactions to teacher talk. ELT Journal, 42 , $109-116$.

Machonis,P. (1985). Transformations of verb phrase idioms: Passivization, particle movement, dative shift. American Speech, 60, 291-308.

McDonald,J.L., \& Carpenter, P.A. (1981). Simultaneous translation: Idiom interpretation and parsing heuristics. Journal of Verbal Learning and Verbal Behavior, 20, 231-247.

Mueller,R.A.G., \& Gibbs,Jr.R.W. (1987). Processing idioms with multiple meanings. Journal of Psycholinguistic Research, 16, 63-81.

Nippold,M.A., \& Martin,S.T. (1989). Idiom interpretation in isolation versus context: A developmental study with adolescents. Journal of Speech and Hearing Research, 32, $59-66$.

Popiel,S.J., \& MCRae,K. (1988). The figurative and literal senses of idioms, or all idioms are not used equally. Journal of Psvcholinguistic Research, 17, 475-487.

Prinz,P.M. (1983). The development of idiomatic meaning in children. Lanquage and Speech, 26, 263-271.

Radin, B. (Ed.). (1985). Dramatic techniques in ESL instruction. New York: City University of New York Hostos Community College. 
Reagan,R.T. (1987). The syntax of English idioms: Can the dog be put on? Journal of Psycholinguistic Research, 16, 417-441.

Ross,J.R. (1981). Idioms and contrastive stress. Studies in Language, $5,273-277$.

Schraw,G., Trathen,W., Reynolds,R.E. \& \& Lapan, R.T. (1988). Preferences for idioms: Restrictions due to lexicalization and familiarity. Journal of Psycholinquistic Research, 17, 413-424.

Schweigert,W.A., \& Moates,D.R. (1988). Familiar idiom comprehension. Journal of Psycholinguistic Research, 17, 281-296.

Silc,K.F. (1990). A cross-cultural training manual. Fairfax County Schools: Virginia.

Smith,M.A., Schloss,P.J., \& Israelite,N.K. (1986). Evaluation of a simile recognition treatment program for hearingimpaired students. Journal of Speech and Hearing Disorders, 51, 134-139.

Sornig,K. (1988). Idioms in language teaching. In W.Hullen, \& R.Schulze(Eds.), Understanding the lexicon: Meaning, sense and world knowledge in lexical semantics (pp.280290). Tubingen: Niemeyer.

Stock,0. (1989). Parsing with flexibility, dynamic strategies, and idioms in mind. Computational Linquistics, 15, 1-18.

Swinney,D.A., \& Cutler,A. (1979). The access and processing of idiomatic expressions. Journal of Learning and Verbal Behavior, 18, 523-534.

Van Lanker,D.R., \& Kempler,D. (1987). Comprehension of familiar phrases by left-but not by right hemisphere damaged patients. Brain and Lanquage, 32, 265-277.

Viteli,J. (1989, September). Learning styles and individual differences in learning English idioms via computer assisted lanquage learning in English as a second language. Paper presented at the annual meeting of the European association of research on learning and instruction, Madrid, Spain. 
Vosniadou,S. (1989). Context and the development of metaphor comprehension. Metaphor and Symbolic Activity, 4, 159171 .

Wilson, D. (1990). Idiom discovery procedure. Notes on Linquistics, $49,4-6$. 
APPENDIXES 
APPENDIX A

Three Scripts for the Video Clips 
Formal Version

Elizabeth: Hello, Margaret. How are you doing?

Margaret : Hi, I'm fine, thank you. And how are you, Elizabeth?

Elizabeth: I'm fine, thanks. Please sit down.

Margaret : Thanks.

Elizabeth: What do you want to do this afternoon?

Margaret : well, would you like to go shopping at Valley Fair?

Elizabeth: That sounds wonderful. Shall I drive?

Margaret : Yes. Would you like to go into every shop?

Elizabeth: No. I have psychology class this afternoon.

Margaret : Which stores would you like to go into?

Elizabeth: We could go to the Gap or Nordstrom's, or Macy's, and perhaps Emporium Capwell. But that is at the other end of the shopping center.

Margaret : Why don't you decide? I'd like to go now.

Elizabeth: You are pressuring me. Would you please stop pushing me?

Margaret : I apologize. I'm really worried about this midterm exam tomorrow. I really must study.

Elizabeth: Please forgive me for being angry. Do you want to meet at noon?

Margaret : That's a good idea.

Elizabeth: Alright. I'll see you at noon. 
Natural Version

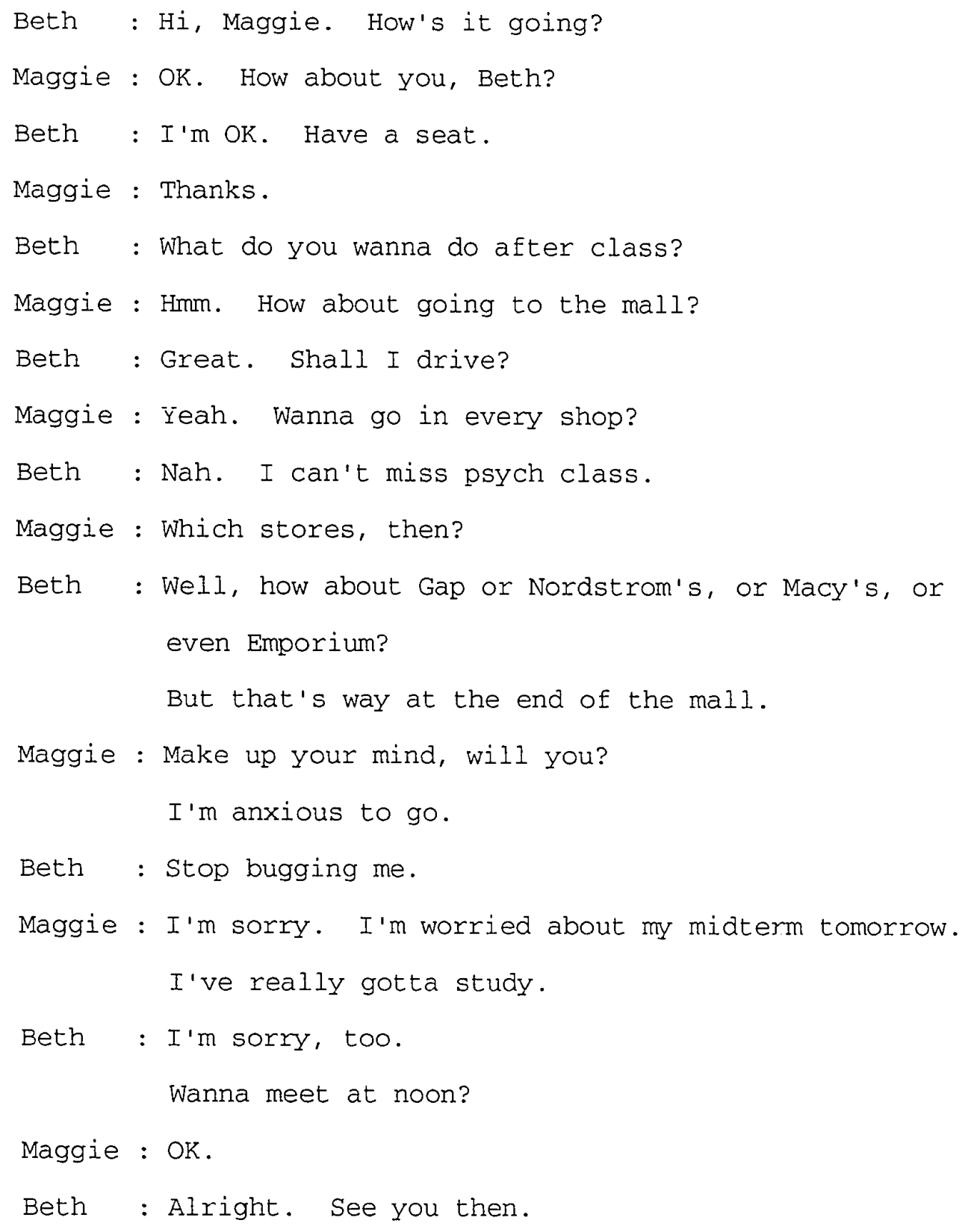


Idiom Version

Libby : Hey, Mags. Whass up?

Mags : Nothin'. What's up with you, Libby?

Libby : Eah, not much. Take a load off.

Mags : Thanks.

Libby : Wanna kill some time after poli sci?

Mags : Yeah. Let's hit the mall.

Libby : Excellent. I've got wheels today.

Mags : Right. You wanna cover the whole place?

Libby : We don't wanna bite off more than we can chew.

And I can't cut psych.

Mags : Well, where?

Libby : How 'bout the Gap and Nordies, and Macy's, or even Emporium? That's a mile away.

Mags : Get your act together. I'm on pins and needles.

Libby : Buzz off! Don't have a cow.

Mags : Well, excuse me. I'm stressed out about this

midterm. I gotta hit the books.

Libby : I'm sorry. I jumped the gun.

Wanna meet at noon?

Mags : I'll be there with bells on.

Libby : Later. 
APPENDIX B

Questionnaires for Native and Non-native Speakers of English 

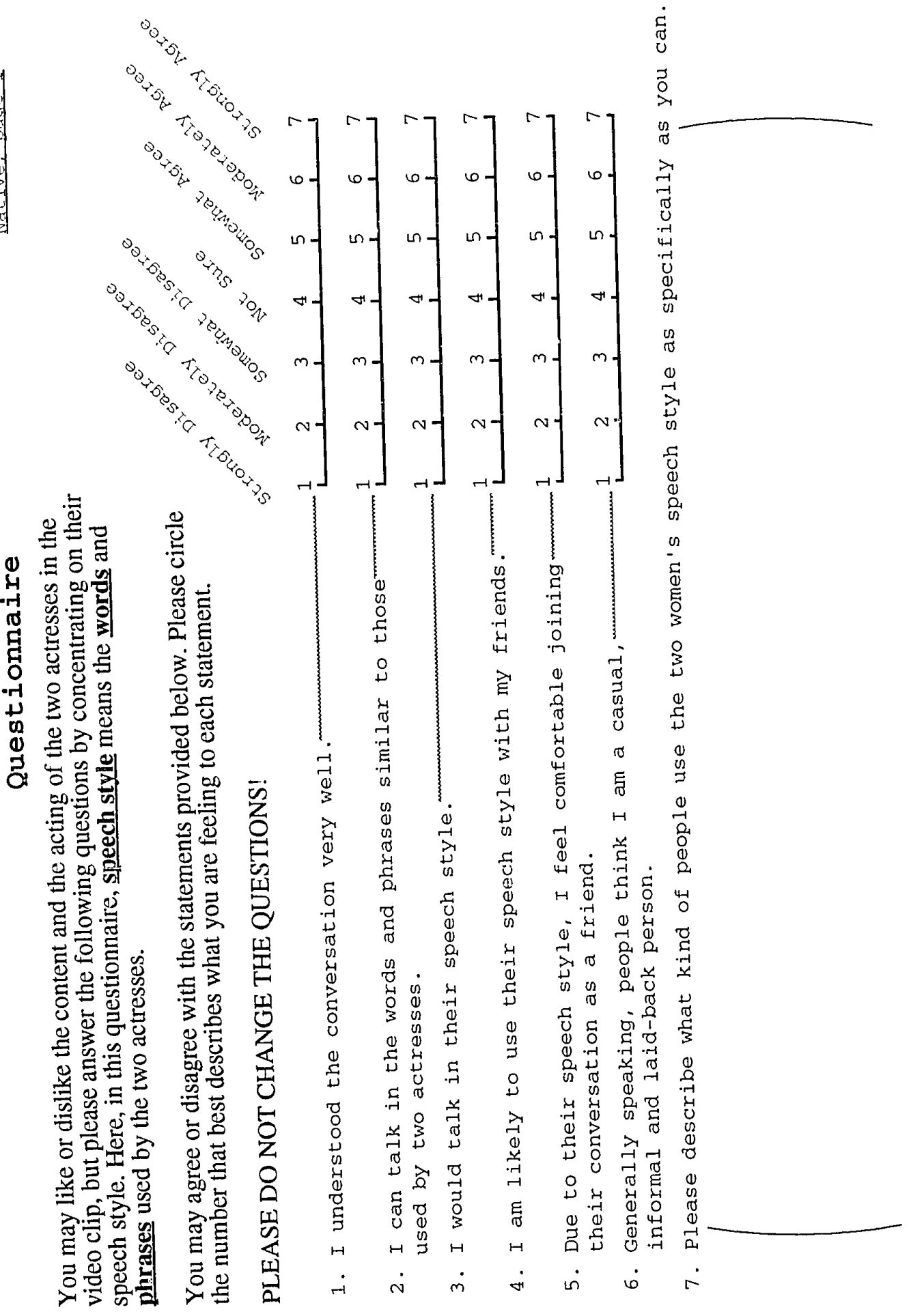


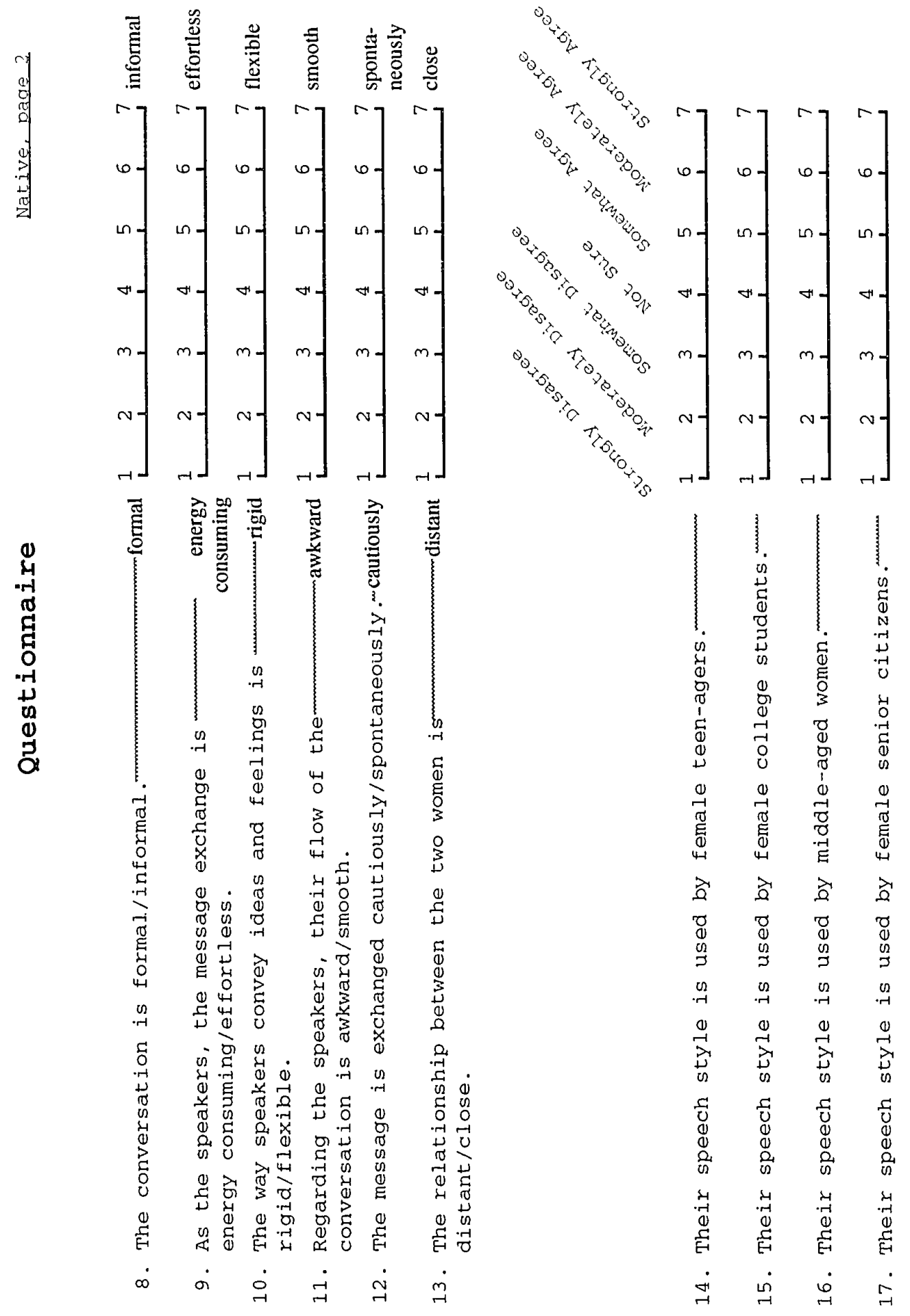




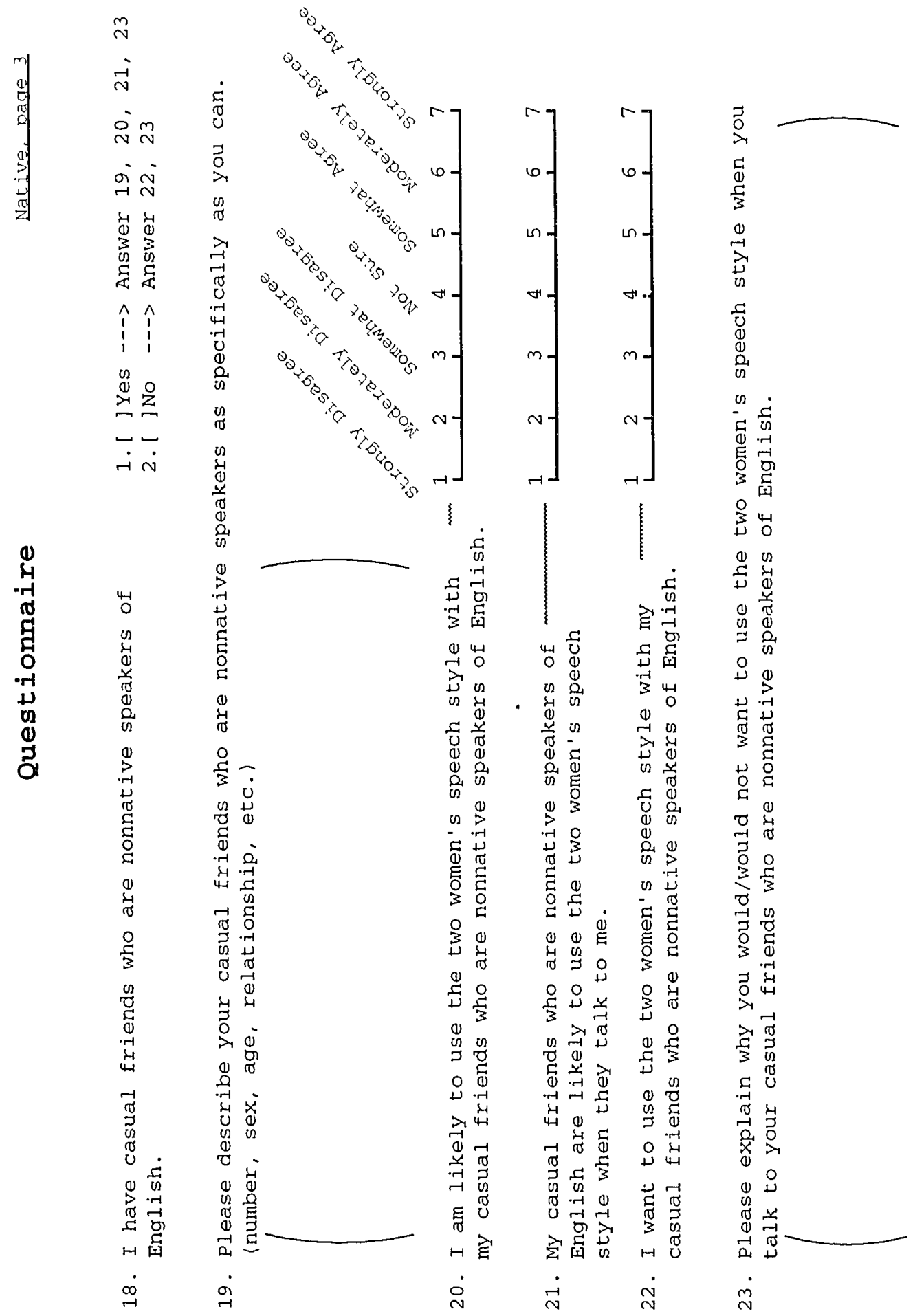



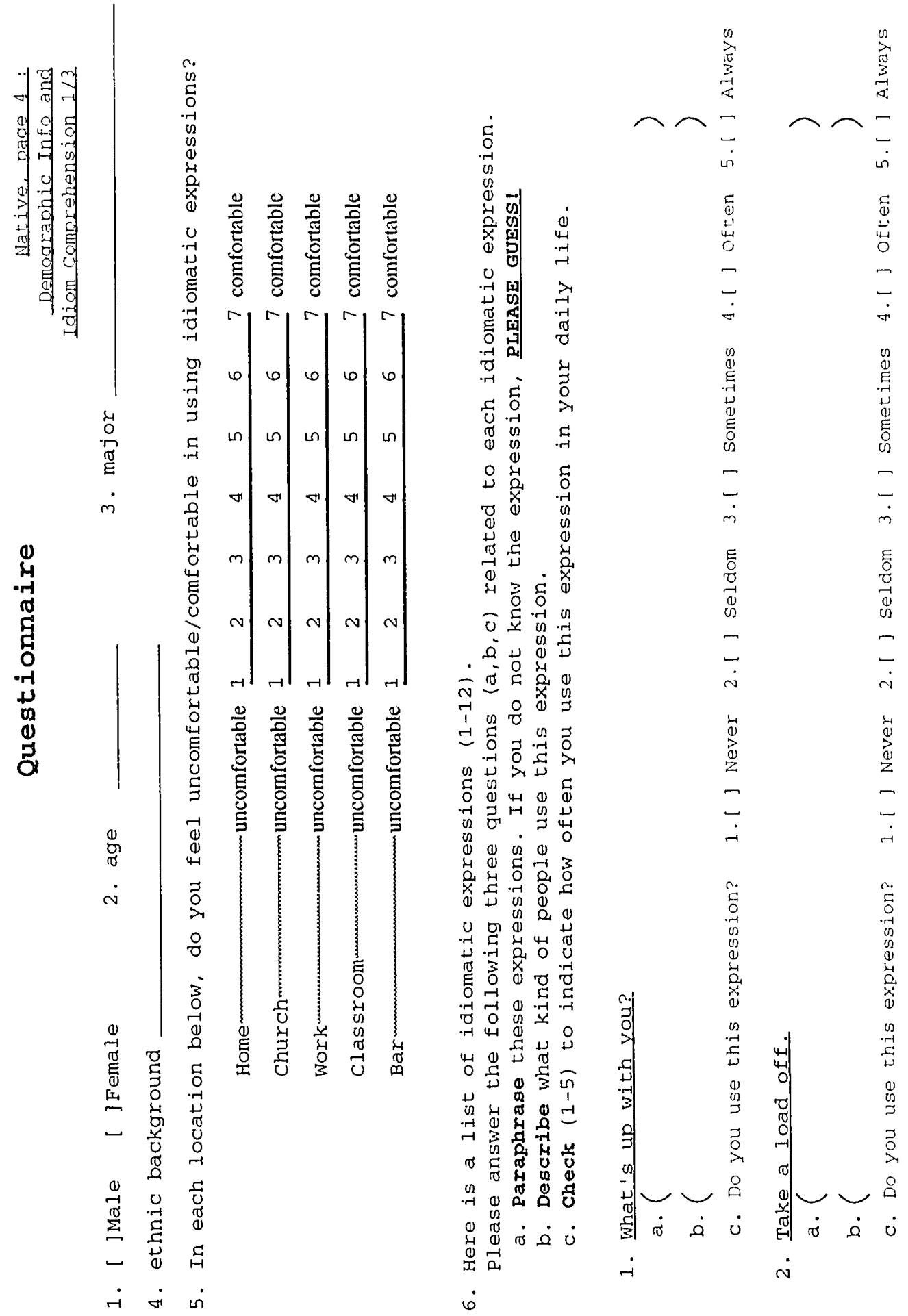

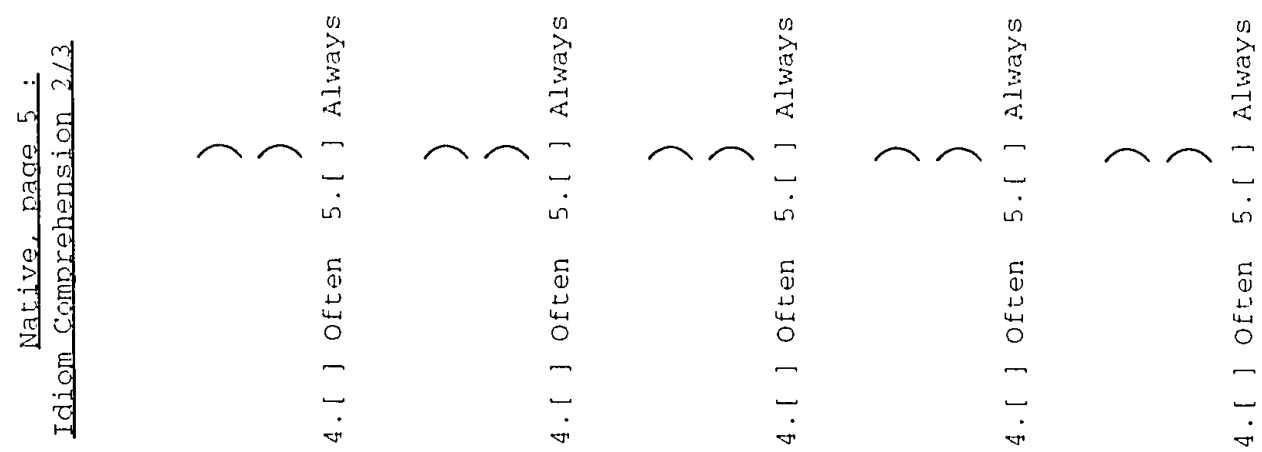

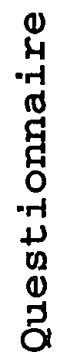
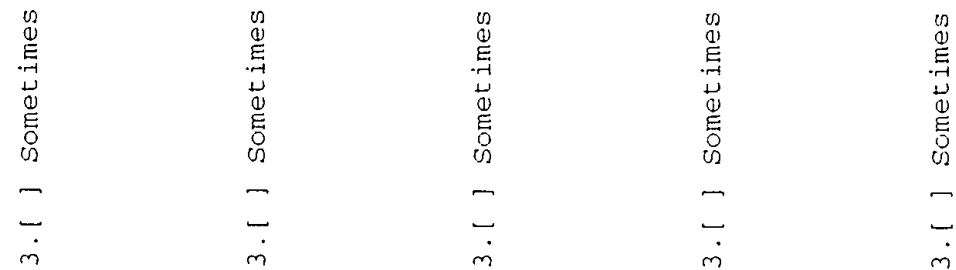

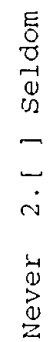

$\begin{array}{ll}\overline{0} & \overline{0} \\ 0 & 0 \\ 0 & 0 \\ 0 & 0 \\ 0 & 0\end{array}$

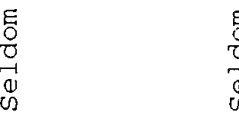

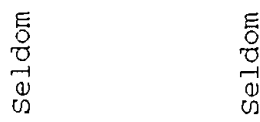

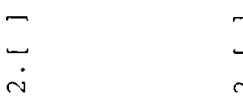

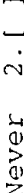

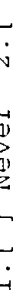

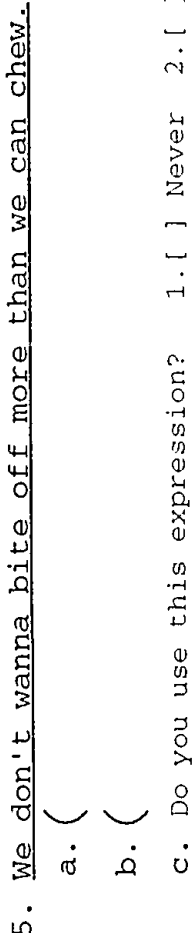

$-$

$\dot{\sim}$

章
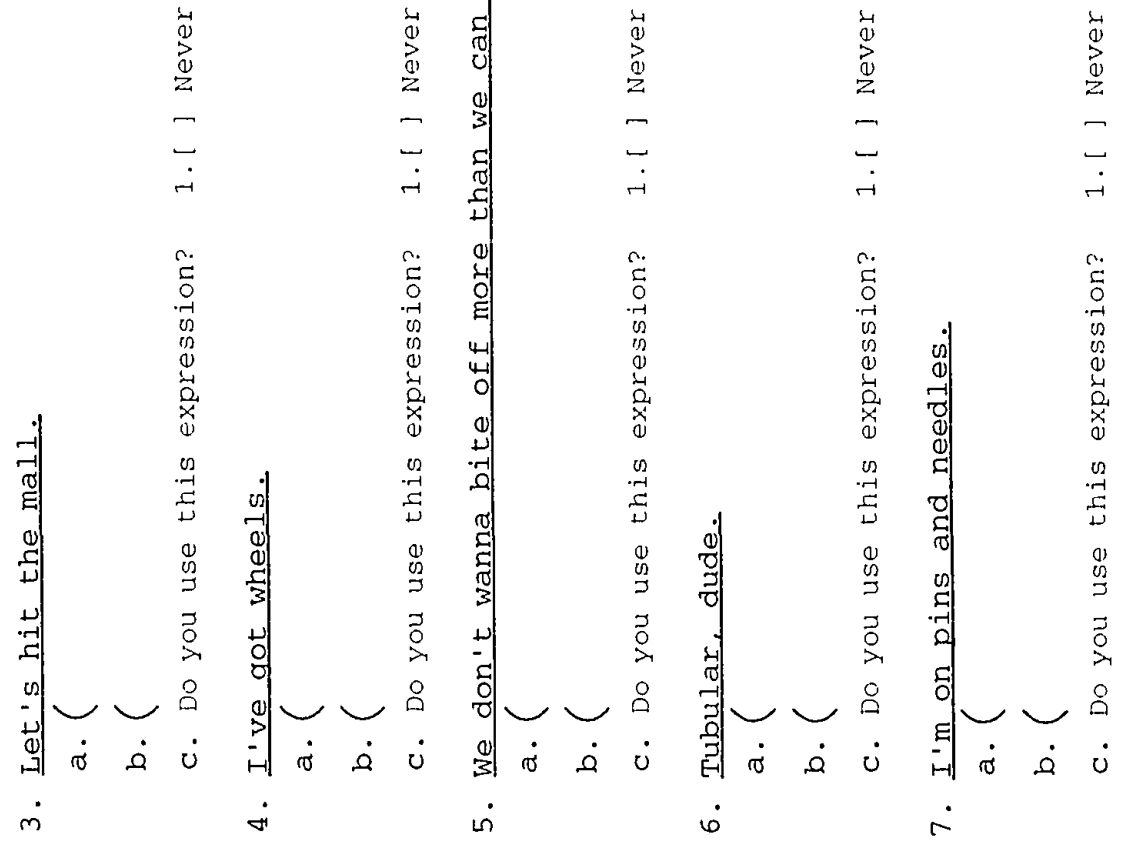

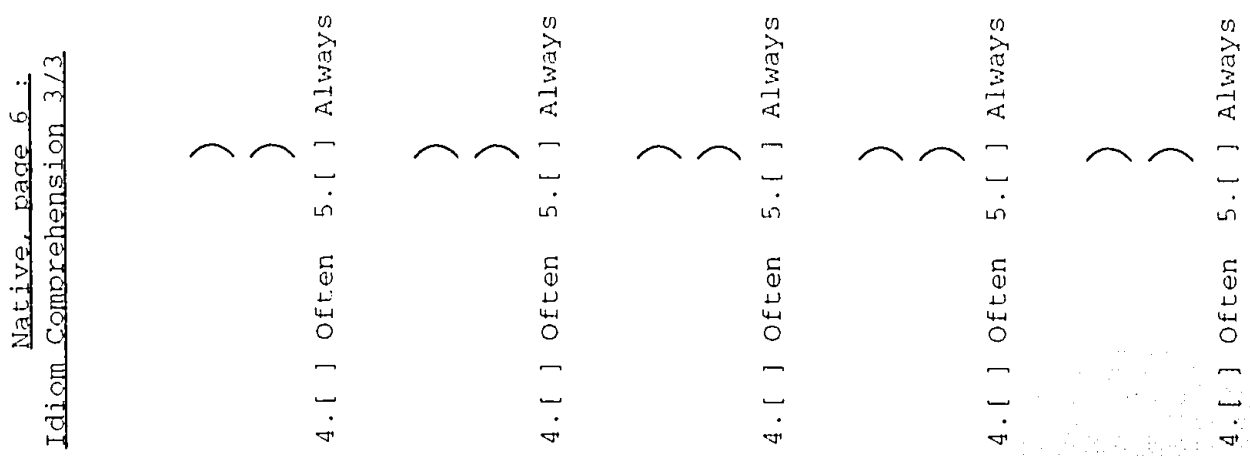

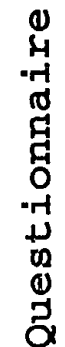
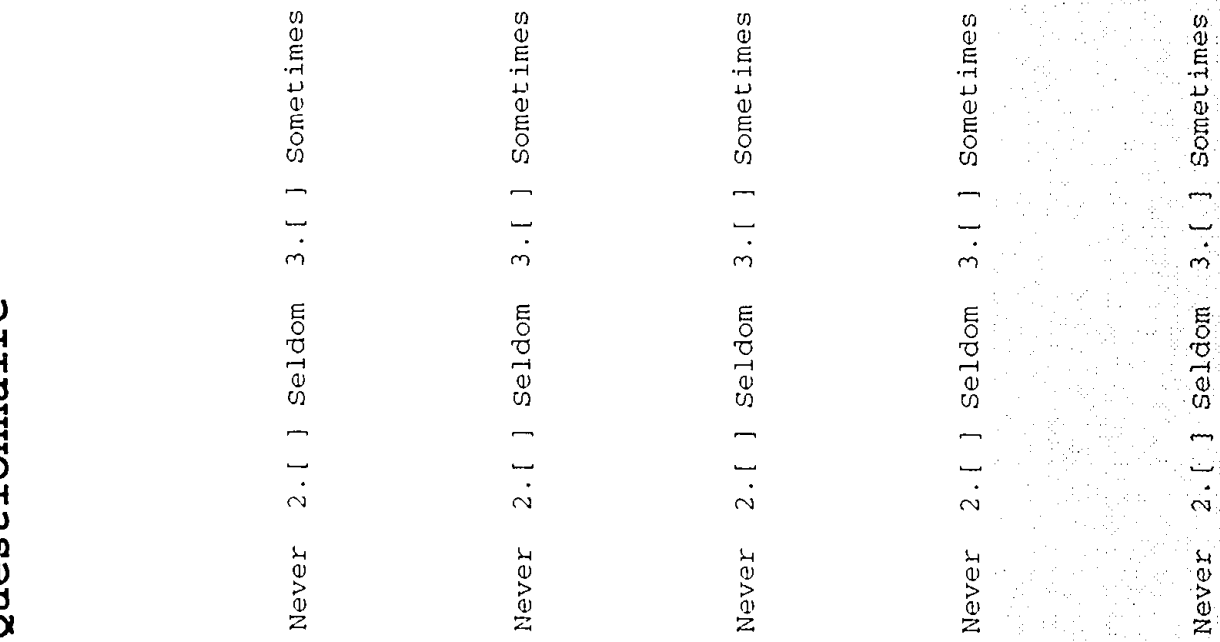

$-2$

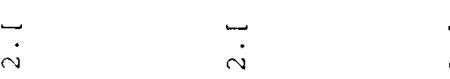

$\stackrel{4}{0}$

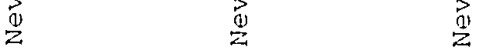

$\begin{array}{ll}-1 & - \\ \check{-} & -\end{array}$
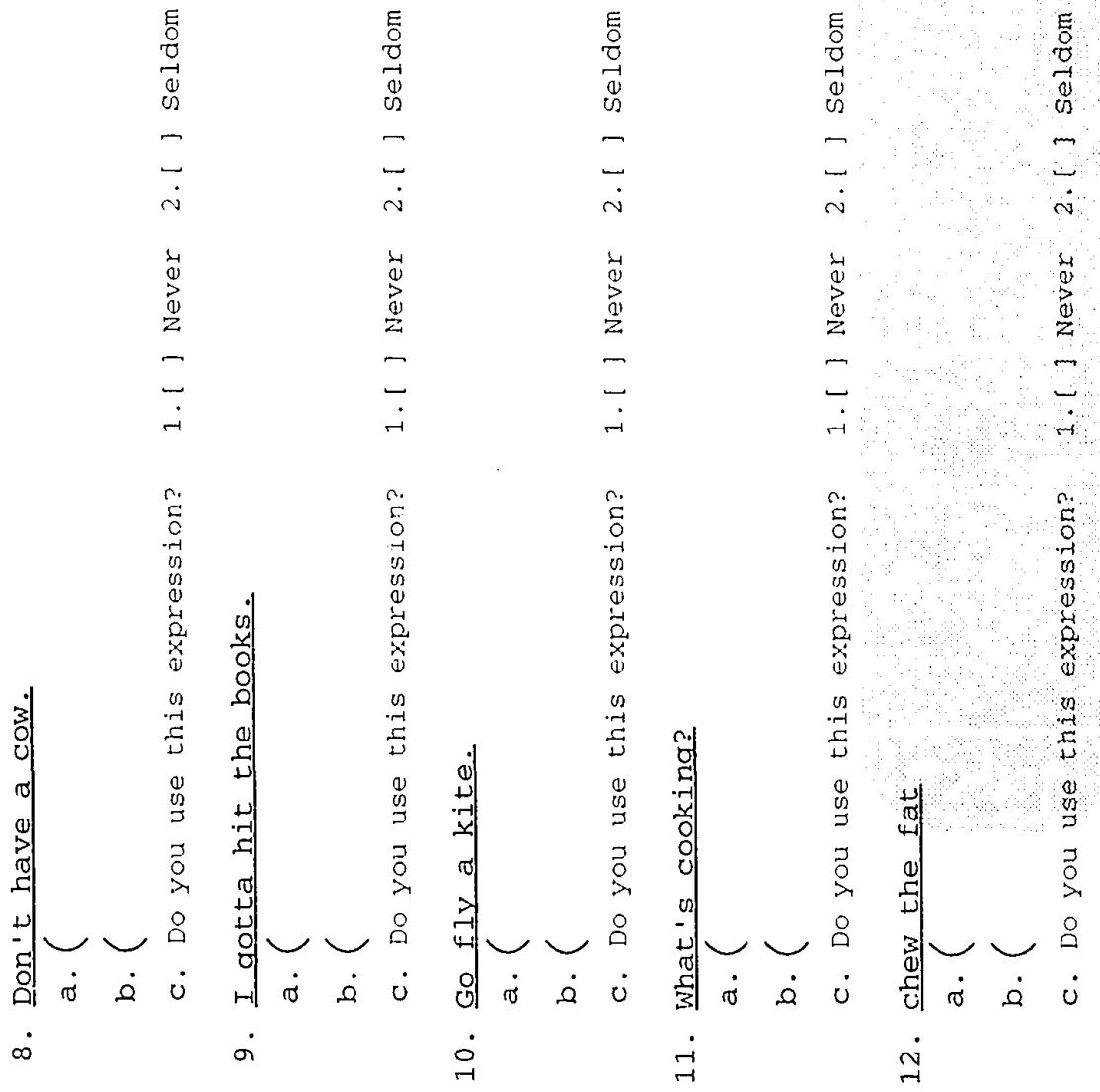

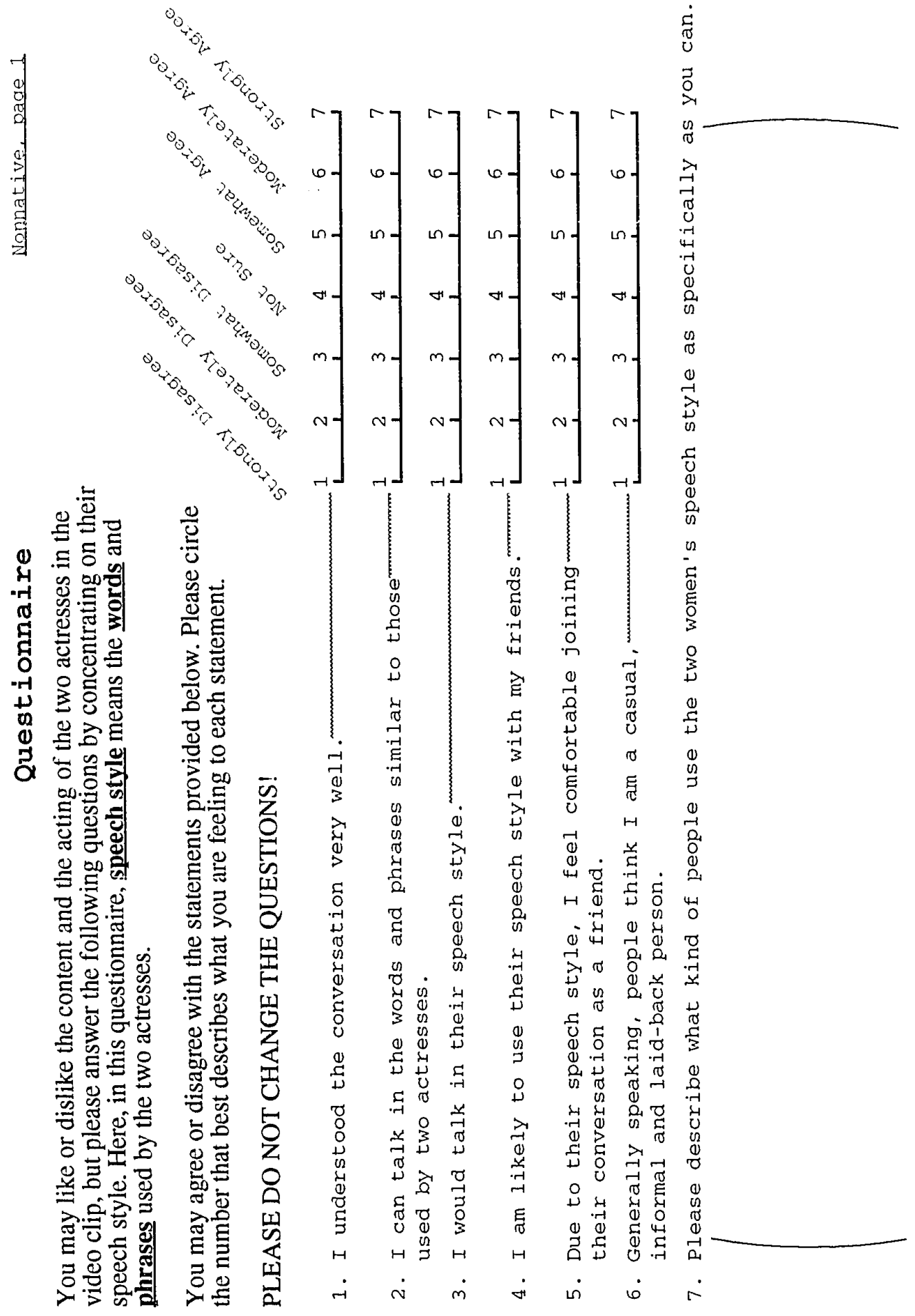


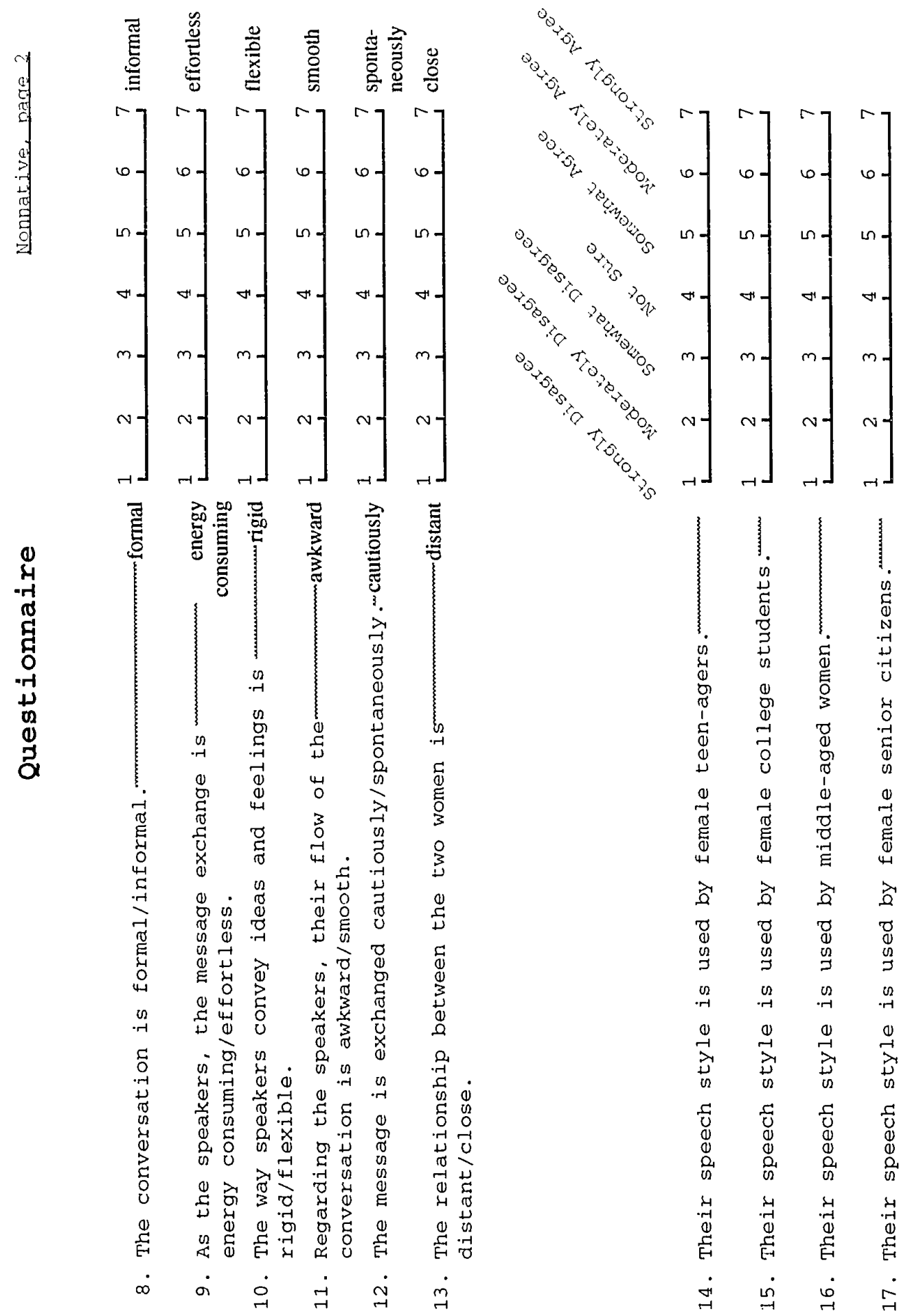




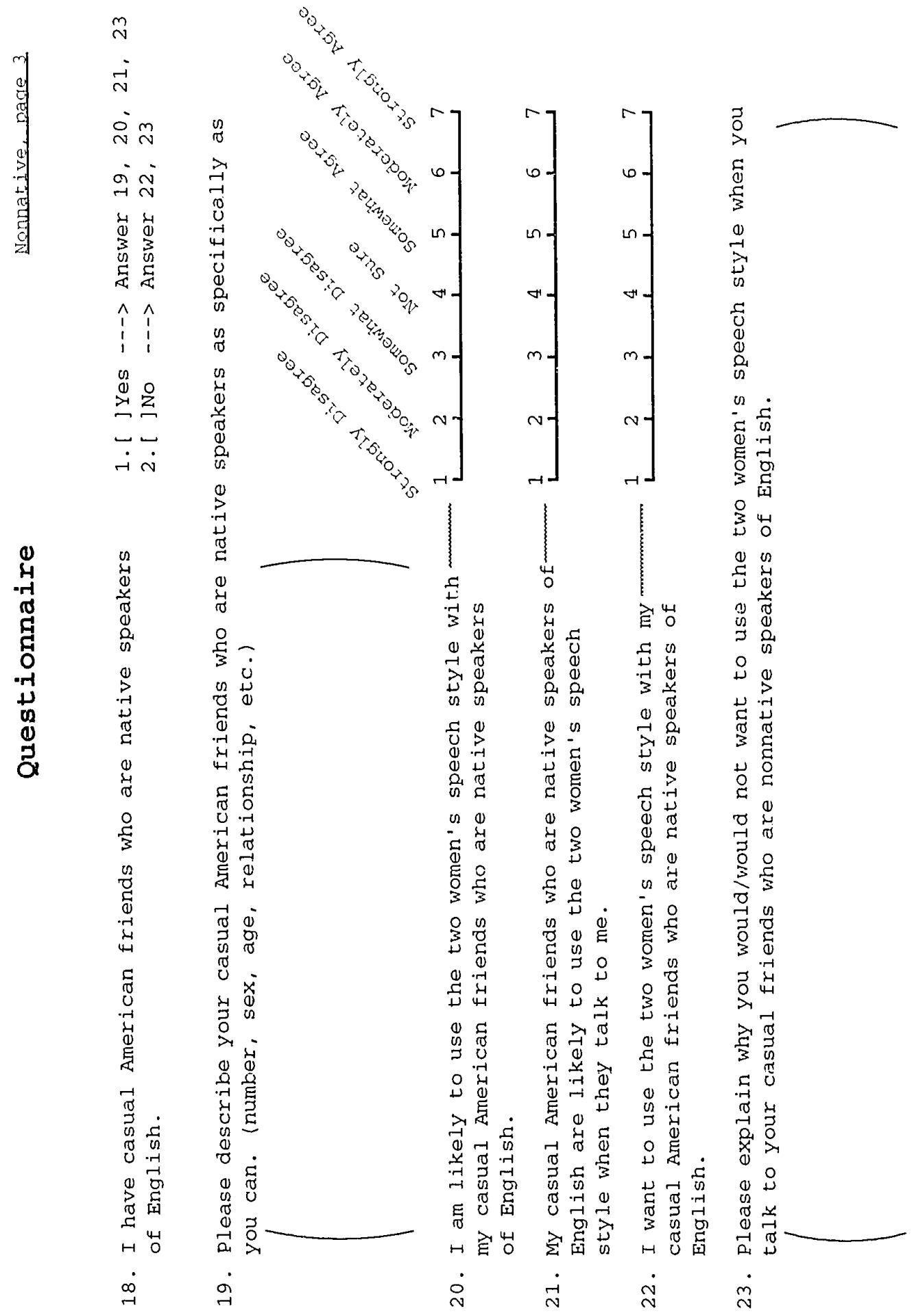



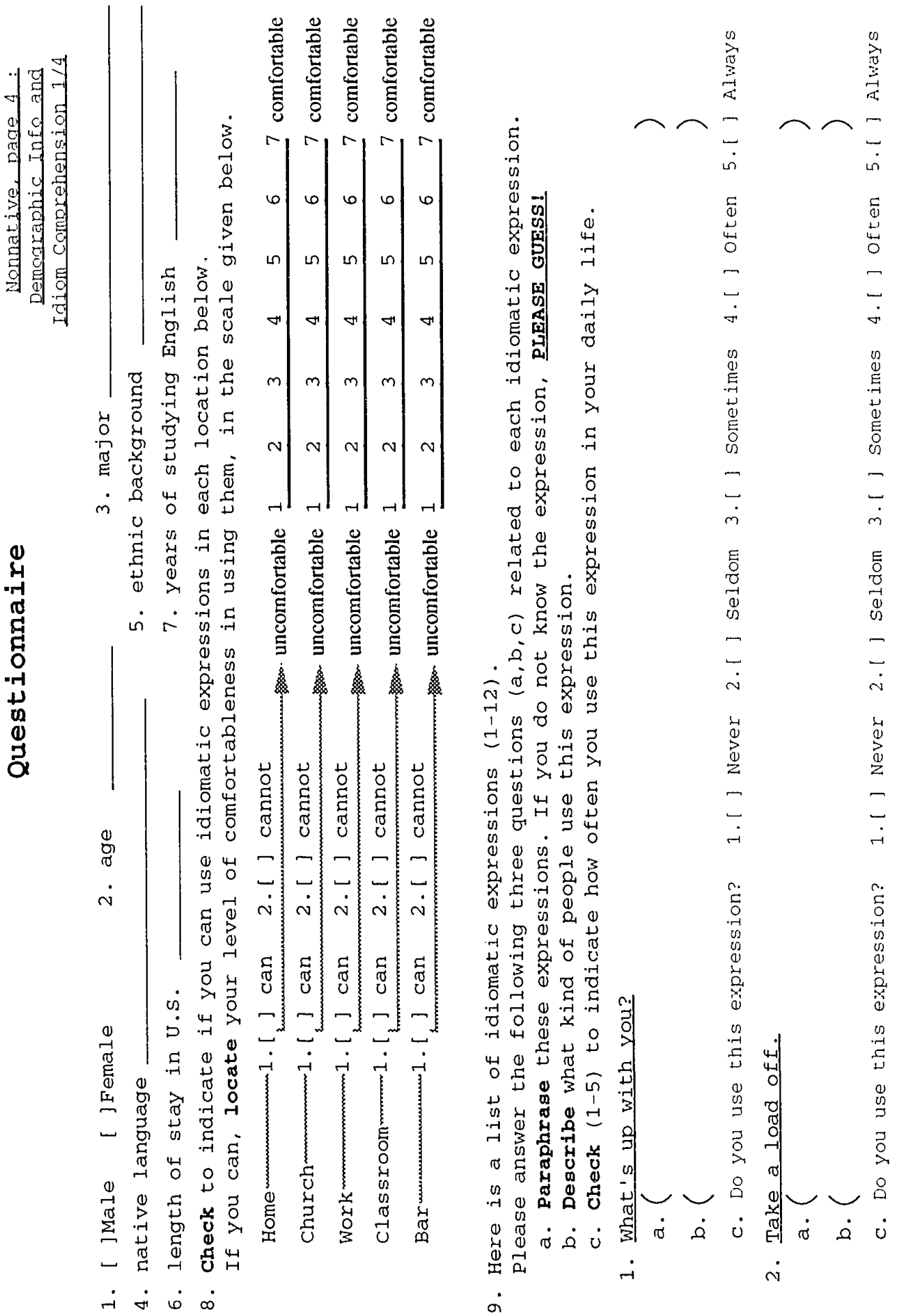

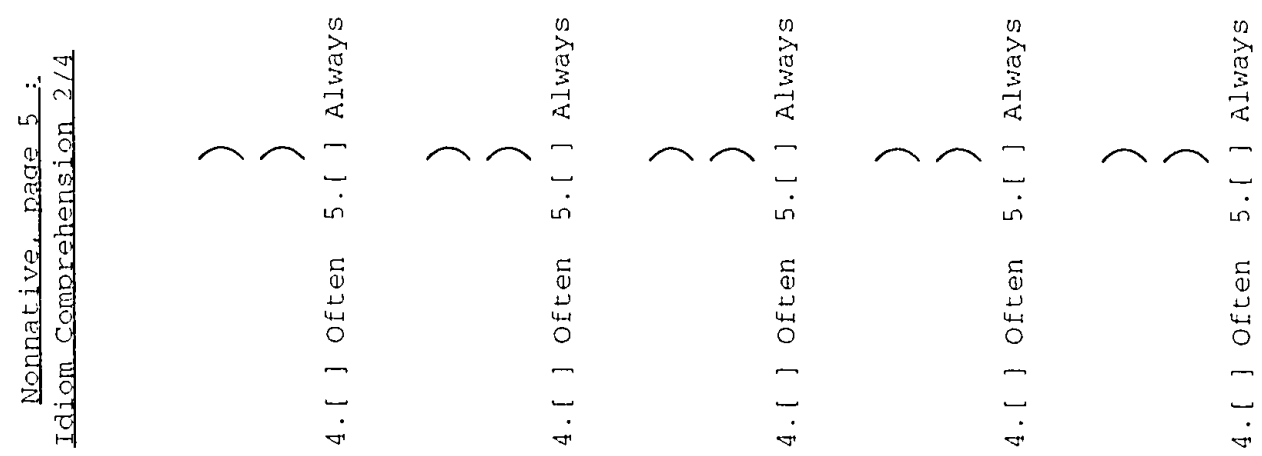

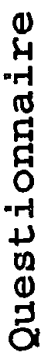
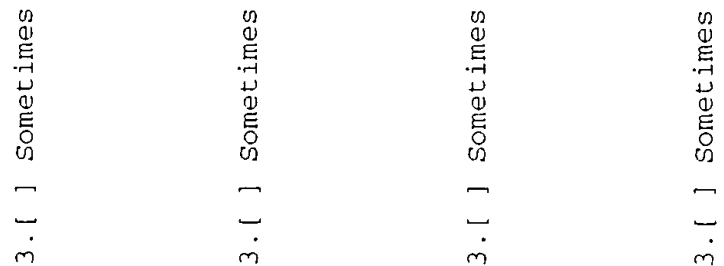

i
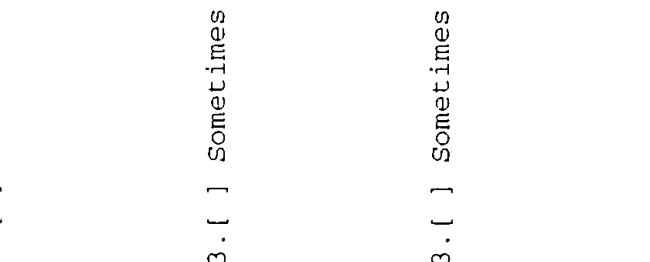

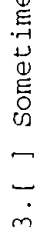

5
$\overline{0}$
0
0
0

E

$=$

s

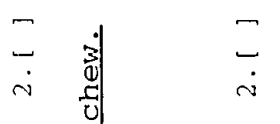

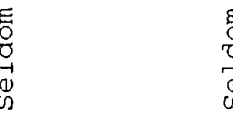

$\sqrt{0}$

$E$
$\overline{0}$
-1
0
0
0

-

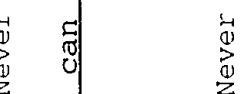

$\stackrel{\substack{0 \\ 0}}{2}$

$-3 \quad 2$
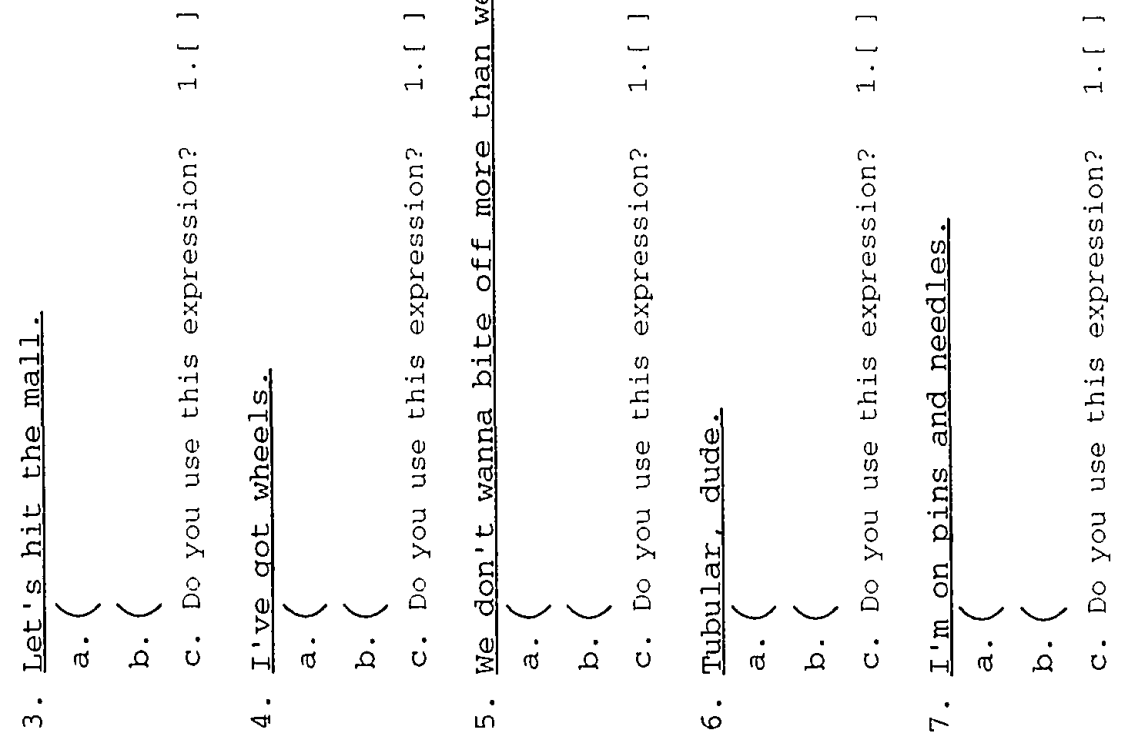

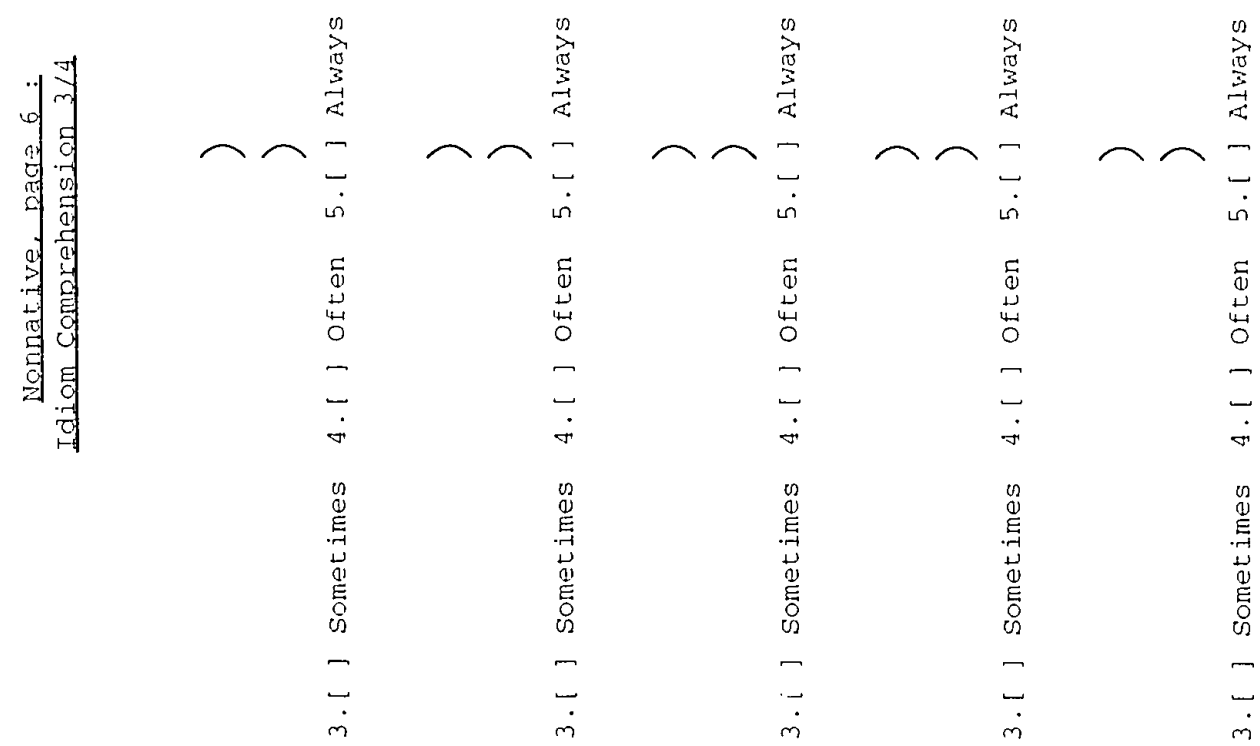

d
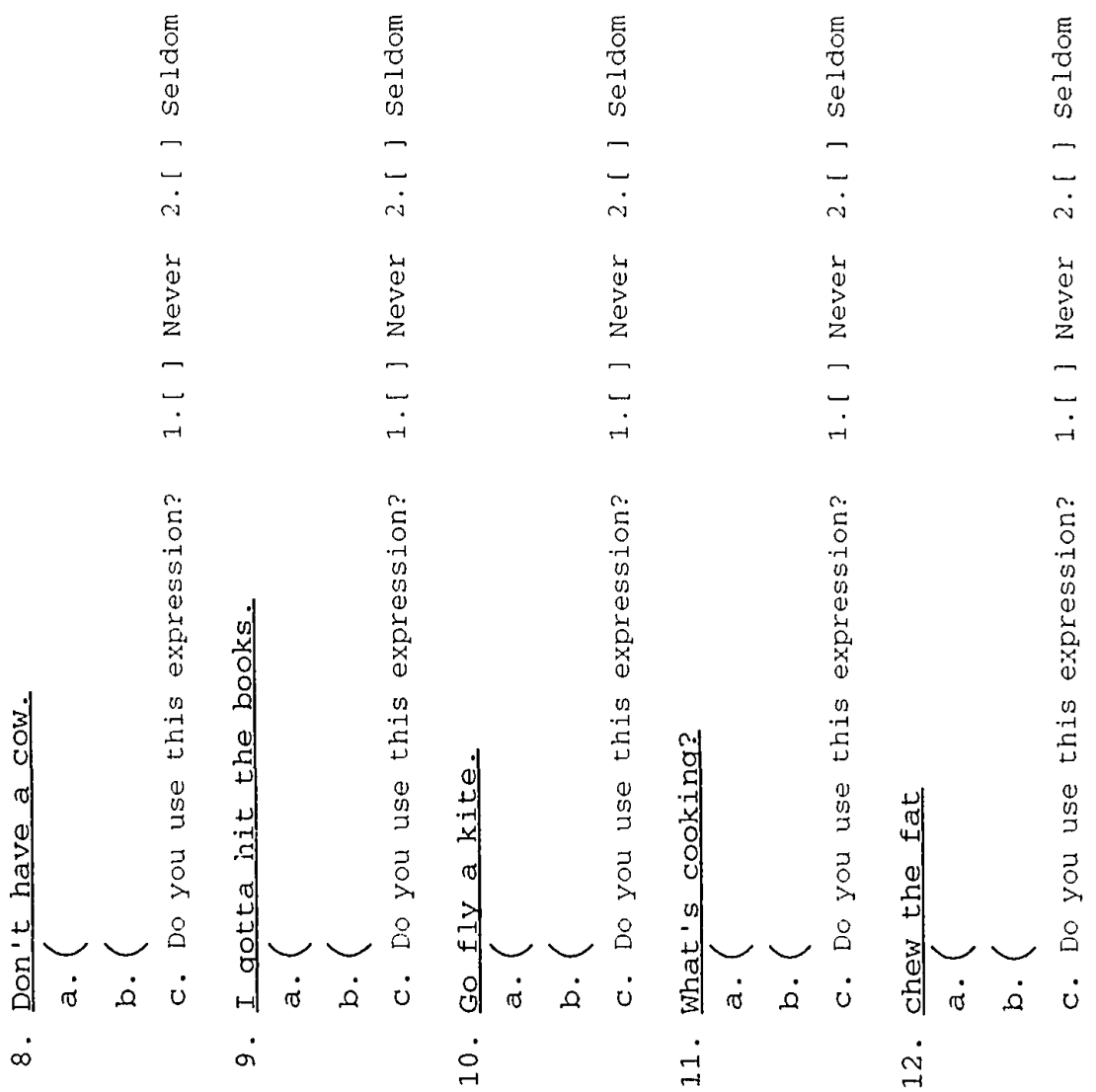

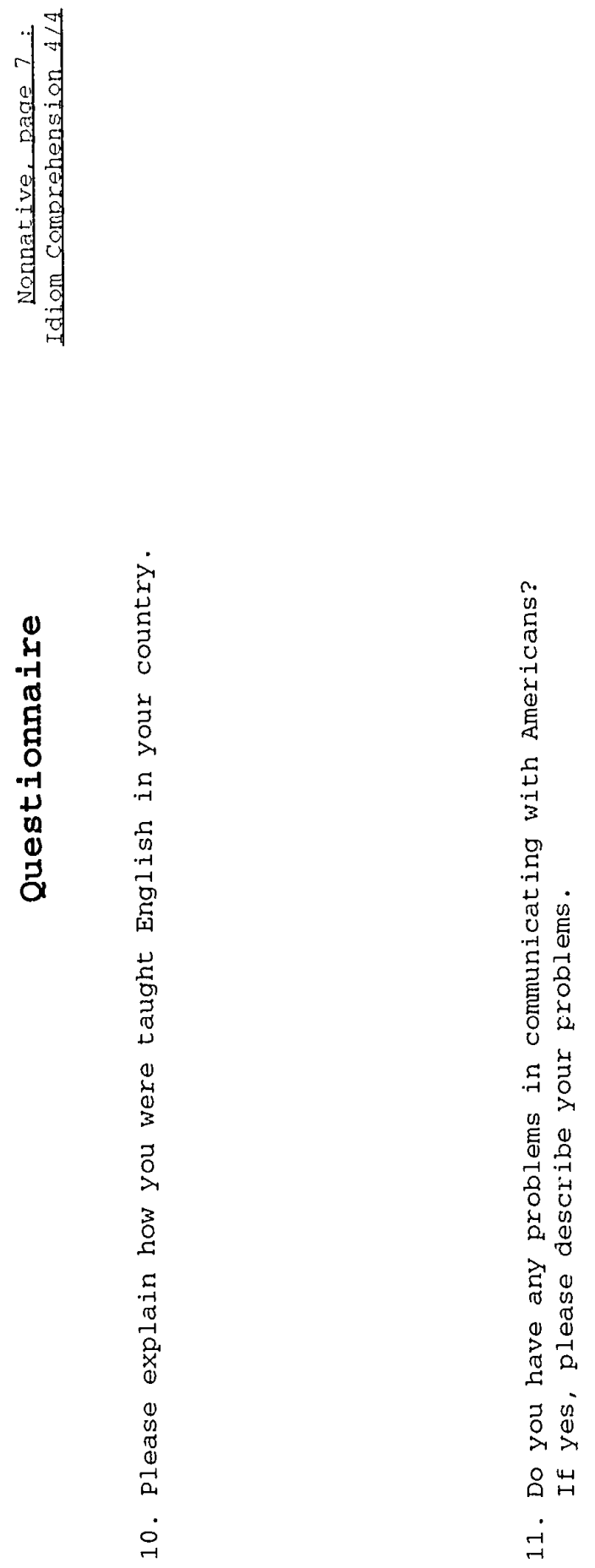
APPENDIX C

Tables 
C.1: Two-Way ANOVA

\begin{tabular}{|c|c|c|c|c|c|}
\hline $\begin{array}{l}\text { Source of } \\
\text { Variation }\end{array}$ & $\begin{array}{r}\text { Sum of } \\
\text { Squares }\end{array}$ & $\mathrm{df}$ & $\begin{array}{l}\text { Mean } \\
\text { Square }\end{array}$ & $F$ & $\begin{array}{l}\text { Signif } \\
\text { of } F\end{array}$ \\
\hline $\begin{array}{l}\text { Main Effects } \\
\text { Speech Style } \\
\text { Non/Native }\end{array}$ & $\begin{array}{r}21.305 \\
6.775 \\
14.231\end{array}$ & $\begin{array}{l}3 \\
2 \\
1\end{array}$ & $\begin{array}{r}7.102 \\
3.387 \\
14.231\end{array}$ & $\begin{array}{l}4.008 \\
1.912 \\
8.031\end{array}$ & $\begin{array}{l}.009 \\
.151 \\
.005\end{array}$ \\
\hline $\begin{array}{l}\text { 2-way interactions } \\
\text { by Speech Style \& } \\
\text { Non/Native }\end{array}$ & 19.699 & 2 & 9.849 & 5.559 & .005 \\
\hline $\begin{array}{l}\text { Explained } \\
\text { Residual } \\
\text { Total }\end{array}$ & $\begin{array}{r}41.004 \\
283.508 \\
324.512 \\
\end{array}$ & $\begin{array}{r}5 \\
160 \\
165 \\
\end{array}$ & $\begin{array}{l}8.201 \\
1.772 \\
1.967 \\
\end{array}$ & 4.628 & .001 \\
\hline
\end{tabular}

Table C.1.1. Comprehension.

\begin{tabular}{lrrrrr}
\hline \multicolumn{1}{c}{$\begin{array}{c}\text { Source of } \\
\text { Variation }\end{array}$} & $\begin{array}{c}\text { Sum of } \\
\text { Squares }\end{array}$ & df & $\begin{array}{c}\text { Mean } \\
\text { Square }\end{array}$ & \multicolumn{1}{c}{$F$} & $\begin{array}{c}\text { Signif } \\
\text { of F }\end{array}$ \\
\hline Main Effects & 90.154 & 3 & 30.051 & 13.206 & $<.001$ \\
$\quad \begin{array}{l}\text { Speech Style } \\
\text { Non/Native }\end{array}$ & 25.771 & 2 & 12.886 & 5.662 & .004 \\
$\quad 63.296$ & 1 & 63.296 & 27.814 & $<.001$ \\
$\begin{array}{l}\text { 2-way interactions } \\
\text { By Speech Style \& }\end{array}$ & 9.452 & 2 & 4.726 & 2.077 & .129 \\
$\quad$ Non/Native & & & & & \\
Explained & 99.606 & 5 & 19.921 & 8.754 & $<.001$ \\
$\begin{array}{l}\text { Residual } \\
\text { Total }\end{array}$ & 364.104 & 160 & 2.276 & & \\
\hline
\end{tabular}

Table C.1.2. Ability.

\begin{tabular}{|c|c|c|c|c|c|}
\hline $\begin{array}{l}\text { Source of } \\
\text { Variation }\end{array}$ & $\begin{array}{r}\text { Sum of } \\
\text { Squares }\end{array}$ & $\mathrm{df}$ & $\begin{array}{l}\text { Mean } \\
\text { Square }\end{array}$ & $F$ & $\begin{array}{l}\text { Signif } \\
\text { of } \mathrm{F}\end{array}$ \\
\hline $\begin{array}{l}\text { Main Effects } \\
\text { Speech Style } \\
\text { Non/Native }\end{array}$ & $\begin{array}{r}101.037 \\
95.571 \\
5.568\end{array}$ & $\begin{array}{l}3 \\
2 \\
1\end{array}$ & $\begin{array}{r}33.679 \\
47.786 \\
5.568\end{array}$ & $\begin{array}{r}10.710 \\
15.195 \\
1.771\end{array}$ & $\begin{array}{l}<.001 \\
<.001 \\
.185\end{array}$ \\
\hline $\begin{array}{l}\text { 2-way interactions } \\
\text { By Speech Style \& } \\
\text { Non/Native }\end{array}$ & 64.703 & 2 & 32.351 & 10.287 & $<.001$ \\
\hline $\begin{array}{l}\text { Explained } \\
\text { Residual } \\
\text { Total }\end{array}$ & $\begin{array}{l}165.740 \\
503.157 \\
668.898\end{array}$ & $\begin{array}{r}5 \\
160 \\
165 \\
\end{array}$ & $\begin{array}{r}33.148 \\
3.145 \\
4.054 \\
\end{array}$ & 10.541 & $<.001$ \\
\hline
\end{tabular}

Table C.1.3. Informality. 


\begin{tabular}{lrrrrr}
\hline \multicolumn{1}{c}{$\begin{array}{c}\text { Source of } \\
\text { Variation }\end{array}$} & $\begin{array}{c}\text { Sum of } \\
\text { Squares }\end{array}$ & df & $\begin{array}{c}\text { Mean } \\
\text { Square }\end{array}$ & F & $\begin{array}{c}\text { Signif } \\
\text { of F }\end{array}$ \\
\hline Main Effects & & & & & \\
$\quad$ Speech Style & 33.066 & 3 & 11.022 & 3.872 & .010 \\
$\quad$ Non/Native & 23.472 & 2 & 11.736 & 4.123 & .018 \\
& 9.484 & 1 & 9.484 & 3.332 & .070 \\
$\begin{array}{l}\text { 2-way interactions } \\
\text { By Speech Siyle \& }\end{array}$ & 49.157 & 2 & 24.579 & 8.636 & $<.001$ \\
$\quad$ Non/Native & & & & & \\
$\quad \begin{array}{lllll}\text { Explained } \\
\text { Residual }\end{array}$ & 82.223 & 5 & 16.445 & 5.778 & $<.001$ \\
Total & 455.392 & 160 & 2.846 & & \\
\hline
\end{tabular}

Table C.1.4. Efficiency.

\begin{tabular}{lrrrrr}
\hline $\begin{array}{l}\text { Source of } \\
\text { Variation }\end{array}$ & $\begin{array}{c}\text { Sum of } \\
\text { Squares }\end{array}$ & df & $\begin{array}{c}\text { Mean } \\
\text { Square }\end{array}$ & \multicolumn{1}{c}{$\mathrm{F}$} & $\begin{array}{c}\text { Signif } \\
\text { of F }\end{array}$ \\
\hline Main Effects & 89.475 & 3 & 29.825 & 11.982 & $<.001$ \\
$\quad$ Speech Style & 80.396 & 2 & 40.198 & 16.149 & $<.001$ \\
$\quad$ Non/Native & 9.267 & 1 & 9.267 & 3.723 & .055 \\
& & & & & \\
2-way interactions & 25.901 & 2 & 12.950 & 5.203 & .006 \\
By Speech Style \& & & & & & \\
$\quad$ Non/Native & 115.376 & 5 & 23.075 & 9.270 & $<.001$ \\
Explained & 398.269 & 160 & 2.489 & & \\
Residual & 513.645 & 165 & 3.113 & & \\
Total & & & & & \\
\hline
\end{tabular}

Table C.1.5. Flexibility.

\begin{tabular}{lrrrrr}
\hline $\begin{array}{c}\text { Source of } \\
\text { Variation }\end{array}$ & $\begin{array}{c}\text { Sum of } \\
\text { Squares }\end{array}$ & \multicolumn{1}{c}{ df } & $\begin{array}{c}\text { Mean } \\
\text { Square }\end{array}$ & \multicolumn{1}{c}{ F } & $\begin{array}{c}\text { Signif } \\
\text { of F }\end{array}$ \\
\hline Main Effects & 41.361 & 3 & 13.787 & 4.206 & .007 \\
$\quad$ Speech Style & 41.255 & 2 & 20.627 & 6.292 & .002 \\
$\quad$ Non/Native & .076 & 1 & .076 & .023 & .879 \\
2-way interactions & & & & & \\
By Speech Style \& & 16.088 & 2 & 8.044 & 2.454 & .089 \\
$\quad$ Non/Native & & & & & \\
Explained & 57.449 & 5 & 11.490 & 3.505 & .005 \\
Residual & 524.509 & 160 & 3.278 & & \\
Total & 581.958 & 165 & 3.527 & & \\
\hline
\end{tabular}

Table C.1.6. Smoothness. 


\begin{tabular}{|c|c|c|c|c|c|}
\hline $\begin{array}{l}\text { Source of } \\
\text { Variation } \\
\end{array}$ & $\begin{array}{r}\text { Sum of } \\
\text { Squares }\end{array}$ & $\mathrm{df}$ & $\begin{array}{c}\text { Mean } \\
\text { Square }\end{array}$ & $F$ & $\begin{array}{l}\text { Signif } \\
\text { of } F\end{array}$ \\
\hline $\begin{array}{l}\text { Main Effects } \\
\text { Speech Style }\end{array}$ & $\begin{array}{l}84.276 \\
70.869\end{array}$ & $\begin{array}{l}3 \\
2\end{array}$ & $\begin{array}{l}28.092 \\
35.434\end{array}$ & $\begin{array}{r}9.257 \\
11.677\end{array}$ & $\begin{array}{l}<.001 \\
<.001\end{array}$ \\
\hline Non/Native & 13.934 & 1 & 13.934 & 4.592 & .034 \\
\hline $\begin{array}{c}\text { 2-way interactions } \\
\text { By Speech Style \& } \\
\text { Non/Native }\end{array}$ & 19.334 & 2 & 9.667 & 3.186 & .044 \\
\hline $\begin{array}{l}\text { Explained } \\
\text { Residual } \\
\text { Total } \\
\end{array}$ & $\begin{array}{l}103.610 \\
488.570 \\
592.180 \\
\end{array}$ & $\begin{array}{r}5 \\
161 \\
166 \\
\end{array}$ & $\begin{array}{r}20.722 \\
3.035 \\
3.567 \\
\end{array}$ & 6.829 & $<.001$ \\
\hline
\end{tabular}

Table C.1.7. Spontaneity.

\begin{tabular}{lrrrrr}
\hline $\begin{array}{c}\text { Source of } \\
\text { Variation }\end{array}$ & $\begin{array}{c}\text { Sum of } \\
\text { Squares }\end{array}$ & df & $\begin{array}{c}\text { Mean } \\
\text { Square }\end{array}$ & $\mathrm{F}$ & $\begin{array}{c}\text { Signif } \\
\text { of F }\end{array}$ \\
\hline Main Effects & 70.852 & 3 & 23.617 & 7.982 & $<.001$ \\
$\quad$ Speech Style & 55.716 & 2 & 27.858 & 9.415 & $<.001$ \\
$\quad$ Non/Native & 15.577 & 1 & 15.577 & 5.264 & .023 \\
2-way interactions & & & & & \\
$\begin{array}{l}\text { By Speech Style \& } \\
\quad \text { Non/Native }\end{array}$ & 14.096 & 2 & 7.048 & 2.382 & .096 \\
$\quad$ & & & & & \\
Explained & 84.948 & 5 & 16.990 & 5.742 & $<.001$ \\
Residual & 476.381 & 161 & 2.959 & & \\
Total & 561.329 & 166 & 3.382 & & \\
\hline
\end{tabular}

Table C.1.8. Closeness.

\begin{tabular}{|c|c|c|c|c|c|}
\hline $\begin{array}{l}\text { Source of } \\
\text { Variation }\end{array}$ & $\begin{array}{l}\text { Sum of } \\
\text { Squares }\end{array}$ & $d f$ & $\begin{array}{c}\text { Mean } \\
\text { Square }\end{array}$ & $F$ & $\begin{array}{l}\text { Signif } \\
\text { of } F\end{array}$ \\
\hline $\begin{array}{l}\text { Main Effects } \\
\text { Speech Style } \\
\text { Non/Native }\end{array}$ & $\begin{array}{r}114.527 \\
106.751 \\
7.559\end{array}$ & $\begin{array}{l}3 \\
2 \\
1\end{array}$ & $\begin{array}{r}38.176 \\
53.375 \\
7.559\end{array}$ & $\begin{array}{r}12.797 \\
17.893 \\
2.534\end{array}$ & $\begin{array}{l}<.001 \\
<.001 \\
.113\end{array}$ \\
\hline $\begin{array}{c}\text { 2-way interactions } \\
\text { By Speech Style \& } \\
\text { Non/Native }\end{array}$ & 20.984 & 2 & 10.492 & 3.517 & .032 \\
\hline $\begin{array}{l}\text { Explained } \\
\text { Residual } \\
\text { Total }\end{array}$ & $\begin{array}{l}135.511 \\
480.274 \\
615.784 \\
\end{array}$ & $\begin{array}{r}5 \\
161 \\
166 \\
\end{array}$ & $\begin{array}{r}27.102 \\
2.983 \\
3.710\end{array}$ & 9.085 & $<.001$ \\
\hline
\end{tabular}

Table C.1.9. Female teen-agers. 


\begin{tabular}{lrrrrr}
\hline $\begin{array}{c}\text { Source of } \\
\text { Variation }\end{array}$ & $\begin{array}{r}\text { Sum of } \\
\text { Squares }\end{array}$ & df & $\begin{array}{c}\text { Mean } \\
\text { Square }\end{array}$ & \multicolumn{1}{c}{$F$} & \multicolumn{1}{c}{$\begin{array}{c}\text { Signif } \\
\text { of } F\end{array}$} \\
\hline Main Effects & 23.145 & 3 & 7.715 & 2.698 & .048 \\
$\quad$ Speech Style & 20.572 & 2 & 10.286 & 3.597 & .030 \\
Non/Native & 2.573 & 1 & 2.573 & .900 & .344 \\
& & & & & \\
2-way interactions & 13.277 & 2 & 6.638 & 2.321 & .101 \\
By Speech Style \& & & & & & \\
$\quad$ Non/Native & 36.422 & 5 & 7.284 & 2.547 & .030 \\
Explained & 460.452 & 161 & 2.860 & & \\
Residual & 496.874 & 166 & 2.993 & & \\
Total & & & & & \\
\hline
\end{tabular}

Table C.1.10. Female college students.

\begin{tabular}{lcrcrr}
\hline $\begin{array}{c}\text { Source of } \\
\text { Variation }\end{array}$ & $\begin{array}{c}\text { Sum of } \\
\text { Squares }\end{array}$ & df & $\begin{array}{c}\text { Mean } \\
\text { Square }\end{array}$ & F & \multicolumn{1}{c}{$\begin{array}{c}\text { Signif } \\
\text { of F }\end{array}$} \\
\hline $\begin{array}{l}\text { Main Effects } \\
\text { Speech Style }\end{array}$ & 60.481 & 3 & 20.160 & 8.520 & $<.001$ \\
$\quad$ Non/Native & 40.461 & 2 & 20.231 & 8.549 & $<.001$ \\
& 19.619 & 1 & 19.619 & 8.291 & .005 \\
2-way interactions & & & & & \\
By Speech Style \& & 9.147 & 2 & 4.573 & 1.933 & .148 \\
$\quad$ NonNative & & & & & \\
Explained & 69.628 & 5 & 13.926 & 5.885 & $<.001$ \\
Residual & 380.983 & 161 & 2.366 & & \\
Total & 450.611 & 166 & 2.715 & & \\
\hline
\end{tabular}

Table C.1.11. Middle-aged women.

\begin{tabular}{lcrrrr}
\hline $\begin{array}{c}\text { Source of } \\
\text { Variation }\end{array}$ & $\begin{array}{c}\text { Sum of } \\
\text { Squares }\end{array}$ & df & $\begin{array}{c}\text { Mean } \\
\text { Square }\end{array}$ & \multicolumn{1}{c}{ F } & \multicolumn{1}{c}{$\begin{array}{c}\text { Signif } \\
\text { of F }\end{array}$} \\
\hline Main Effects & 88.469 & 3 & 29.490 & 12.791 & $<.001$ \\
$\quad \begin{array}{l}\text { Speech Style } \\
\text { Non/Native }\end{array}$ & 70.255 & 2 & 35.128 & 15.237 & $<.001$ \\
& 17.758 & 1 & 17.758 & 7.703 & .006 \\
2-way interactions & & & & & \\
By Speech Style \& & 21.604 & 2 & 10.802 & 4.685 & .011 \\
$\quad$ Non/Native & & & & & \\
Explained & 110.072 & 5 & 22.014 & & \\
Residual & 371.185 & 161 & 2.305 & & \\
Total & 481.257 & 166 & 2.899 & & \\
\hline
\end{tabular}

Table C.1.12. Female senior citizens. 
C.2: One-Way ANOVA: Native Speakers

\begin{tabular}{lcrrrc}
\hline $\begin{array}{l}\text { Source of } \\
\text { Variation }\end{array}$ & $\begin{array}{c}\text { Sum of } \\
\text { Squares }\end{array}$ & df & $\begin{array}{c}\text { Mean } \\
\text { Square }\end{array}$ & $F$ & $\begin{array}{c}\text { Signif } \\
\text { of F }\end{array}$ \\
\hline Main Effects & 158.167 & 2 & 79.083 & 32.742 & $<.001$ \\
$\quad$ Speech Style & 158.167 & 2 & 79.083 & 32.742 & $<.001$ \\
& & & & & \\
Explained & 158.167 & 2 & 79.083 & 32.742 & $<.001$ \\
Residual & 195.643 & 81 & 2.415 & & \\
Total & 353.810 & 83 & 4.263 & & \\
\hline
\end{tabular}

Table C.2.1. Perceived interpersonal relationship: Informality by speech style.

\begin{tabular}{lccccc}
\hline \multicolumn{1}{c}{$\begin{array}{l}\text { Source of } \\
\text { Variation }\end{array}$} & $\begin{array}{c}\text { Sum of } \\
\text { Squares }\end{array}$ & df & $\begin{array}{c}\text { Mean } \\
\text { Square }\end{array}$ & $\mathrm{F}$ & $\begin{array}{c}\text { Signif } \\
\text { of F }\end{array}$ \\
\hline Main Effects & 65.429 & 2 & 32.714 & 12.636 & $<.001$ \\
$\quad$ Speech Style & 65.429 & 2 & 32.714 & 12.636 & $<.001$ \\
& & & & & \\
Explained & 65.429 & 2 & 32.714 & 12.636 & $<.001$ \\
Residual & 209.714 & 81 & 2.589 & & \\
Total & 275.143 & 83 & 3.315 & & \\
\hline
\end{tabular}

Table C.2.2. Perceived interpersonal relationship: Efficiency by speech style.

\begin{tabular}{lccccc}
\hline \multicolumn{1}{c}{$\begin{array}{l}\text { Source of } \\
\text { Variation }\end{array}$} & $\begin{array}{c}\text { Sum of } \\
\text { Squares }\end{array}$ & $\mathrm{df}$ & $\begin{array}{c}\text { Mean } \\
\text { Square }\end{array}$ & $\mathrm{F}$ & $\begin{array}{c}\text { Signif } \\
\text { of } \mathrm{F}\end{array}$ \\
\hline Main Effects & $98<.001$ & 2 & $49<.001$ & 21.076 & $<.001$ \\
$\quad$ Speech Style & $98<.001$ & 2 & $49<.001$ & 21.076 & $<.001$ \\
& & & & & \\
Explained & $98<.001$ & 2 & $49<.001$ & 21.076 & $<.001$ \\
Residual & 188.321 & 81 & 2.325 & & \\
Total & 286.321 & 83 & 3.450 & & \\
\hline
\end{tabular}

Table C.2.3. Perceived interpersonal relationship: Flexibility by speech style.

\begin{tabular}{lccccc}
\hline $\begin{array}{c}\text { Source of } \\
\text { Variation }\end{array}$ & $\begin{array}{c}\text { Sum of } \\
\text { Squares }\end{array}$ & df & $\begin{array}{c}\text { Mean } \\
\text { Square }\end{array}$ & F & $\begin{array}{c}\text { Signif } \\
\text { of } F\end{array}$ \\
\hline Main Effects & 52.286 & 2 & 26.143 & 8.461 & $<.001$ \\
Speech Style & 52.286 & 2 & 26.143 & 8.461 & $<.001$ \\
& & & & & \\
Explained & 52.286 & 2 & 26.143 & 8.461 & $<.001$ \\
Residual & 250.286 & 81 & 3.090 & & \\
Total & 302.571 & 83 & 3.645 & & \\
\hline
\end{tabular}

Table C.2.4. Perceived interpersonal relationship: Smoothness by speech style. 


\begin{tabular}{lcrrrc}
\hline \multicolumn{1}{c}{$\begin{array}{c}\text { Source of } \\
\text { Variation }\end{array}$} & $\begin{array}{c}\text { Sum of } \\
\text { Squares }\end{array}$ & df & $\begin{array}{c}\text { Mean } \\
\text { Square }\end{array}$ & $F$ & $\begin{array}{c}\text { Signif } \\
\text { of } F\end{array}$ \\
\hline Main Effects & 82.357 & 2 & 41.179 & 16.971 & $<.001$ \\
$\quad$ Speech Style & 82.357 & 2 & 41.179 & 16.971 & $<.001$ \\
& & & & & \\
Explained & 82.357 & 2 & 41.179 & 16.971 & $<.001$ \\
$\begin{array}{l}\text { Residual } \\
\text { Total }\end{array}$ & 196.536 & 81 & 2.426 & & \\
\hline
\end{tabular}

Table C.2.5. Perceived interpersonal relationship: Spontaneity by speech style.

\begin{tabular}{lrrrrc}
\hline $\begin{array}{l}\text { Source of } \\
\text { Variation }\end{array}$ & $\begin{array}{c}\text { Sum of } \\
\text { Squares }\end{array}$ & df & $\begin{array}{c}\text { Mean } \\
\text { Square }\end{array}$ & $\mathrm{F}$ & $\begin{array}{c}\text { Signif } \\
\text { of } \mathrm{F}\end{array}$ \\
\hline Main Effects & 35.310 & 2 & 17.655 & 7.830 & .001 \\
$\quad$ Speech Style & 35.310 & 2 & 17.655 & 7.830 & .001 \\
& & & & & \\
Explained & 35.310 & 2 & 17.655 & 7.830 & .001 \\
Residual & 182.643 & 81 & 2.255 & & \\
Total & 217.952 & 83 & 2.626 & & \\
\hline
\end{tabular}

Table C.2.6. Perceived interpersonal relationship: Closeness by speech style.

\begin{tabular}{lcrrrc}
\hline $\begin{array}{c}\text { Source of } \\
\text { Variation }\end{array}$ & $\begin{array}{c}\text { Sum of } \\
\text { Squares }\end{array}$ & df & $\begin{array}{c}\text { Mean } \\
\text { Square }\end{array}$ & F & $\begin{array}{c}\text { Signif } \\
\text { of } F\end{array}$ \\
\hline Main Effects & 108.643 & 2 & 54.321 & 20.029 & $<.001$ \\
$\quad$ Speech Style & 108.643 & 2 & 54.321 & 20.029 & $<.001$ \\
Explained & 108.643 & 2 & 54.321 & 20.029 & $<.001$ \\
Residual & 219.679 & 81 & 2.712 & & \\
Total & 328.321 & 83 & 3.956 & & \\
\hline
\end{tabular}

Table C.2.7. Generation identification: Female teen-agers by speech style.

\begin{tabular}{lcrccc}
\hline $\begin{array}{l}\text { Source of } \\
\text { Variation }\end{array}$ & $\begin{array}{c}\text { Sum of } \\
\text { Squares }\end{array}$ & df & $\begin{array}{c}\text { Mean } \\
\text { Square }\end{array}$ & $F$ & $\begin{array}{c}\text { Signif } \\
\text { of } F\end{array}$ \\
\hline Main Effects & 29.786 & 2 & 14.893 & 5.965 & .004 \\
$\quad$ Speech Style & 29.786 & 2 & 14.893 & 5.965 & .004 \\
& & & & & \\
Explained & 29.786 & 2 & 14.893 & 5.965 & .004 \\
Residual & 202.250 & 81 & 2.497 & & \\
Total & 232.036 & 83 & 2.796 & & \\
\hline
\end{tabular}

Table C.2.8. Generation identification: Female college students by speech style. 


\begin{tabular}{lcrrrr}
\hline $\begin{array}{l}\text { Source of } \\
\text { Variation }\end{array}$ & $\begin{array}{c}\text { Sum of } \\
\text { Squares }\end{array}$ & df & $\begin{array}{c}\text { Mean } \\
\text { Square }\end{array}$ & $F$ & $\begin{array}{c}\text { Signif } \\
\text { of } F\end{array}$ \\
\hline Main Effects & 36.167 & 2 & 18.083 & 8.577 & $<.001$ \\
$\quad$ Speech Style & 36.167 & 2 & 18.083 & 8.577 & $<.001$ \\
& & & & & \\
Explained & 36.167 & 2 & 18.083 & 8.577 & $<.001$ \\
Residual & 170.786 & 81 & 2.108 & & \\
Total & 206.952 & 83 & 2.493 & & \\
\hline
\end{tabular}

Tabie C.2.9. Generation identification: Middle-aged women by speech style.

\begin{tabular}{lcrrrc}
\hline \multicolumn{1}{c}{$\begin{array}{l}\text { Source of } \\
\text { Variation }\end{array}$} & $\begin{array}{c}\text { Sum of } \\
\text { Squares }\end{array}$ & df & $\begin{array}{c}\text { Mean } \\
\text { Square }\end{array}$ & $F$ & $\begin{array}{c}\text { Signif } \\
\text { of } F\end{array}$ \\
\hline Main Effects & 69.429 & 2 & 34.714 & 22.514 & $<.001$ \\
$\quad$ Speech Style & 69.429 & 2 & 34.714 & 22.514 & $<.001$ \\
& & & & & \\
Explained & 69.429 & 2 & 34.714 & 22.514 & $<.001$ \\
Residual & 124.893 & 81 & 1.542 & & \\
Total & 194.321 & 83 & 2.341 & & \\
\hline
\end{tabular}

Table C.2.10. Generation identification: Female senior citizens by speech style. 
C.3 One-Way ANOVA: Non-native Speakers

\begin{tabular}{lcrrrc}
\hline \multicolumn{1}{c}{$\begin{array}{c}\text { Source of } \\
\text { Variation }\end{array}$} & $\begin{array}{c}\text { Sum of } \\
\text { Squares }\end{array}$ & df & $\begin{array}{c}\text { Mean } \\
\text { Square }\end{array}$ & $F$ & $\begin{array}{c}\text { Signif } \\
\text { of F }\end{array}$ \\
\hline Main Effects & 24.164 & 2 & 12.082 & 6.256 & .003 \\
$\quad$ Speech Style & 24.164 & 2 & 12.082 & 6.256 & .003 \\
& & & & & \\
Explained & 24.164 & 2 & 12.082 & 6.256 & .003 \\
Residual & 152.580 & 79 & 1.931 & & \\
Total & 176.744 & 81 & 2.182 & & \\
\hline
\end{tabular}

Table C.3.1. Comprehension by speech style.

\begin{tabular}{lcrrcc}
\hline \multicolumn{1}{c}{$\begin{array}{c}\text { Source of } \\
\text { Variation }\end{array}$} & $\begin{array}{c}\text { Sum of } \\
\text { Squares }\end{array}$ & df & $\begin{array}{c}\text { Mean } \\
\text { Square }\end{array}$ & $F$ & $\begin{array}{c}\text { Signif } \\
\text { of } F\end{array}$ \\
\hline Main Effects & 31.723 & 2 & 15.862 & 6.525 & .002 \\
$\quad$ Speech Style & 31.723 & 2 & 15.862 & 6.525 & .002 \\
& & & & & \\
Explained & 31.723 & 2 & 15.862 & 6.525 & .002 \\
Residual & 192.033 & 79 & 2.431 & & \\
Total & 223.756 & 81 & 2.762 & & \\
\hline
\end{tabular}

Table C.3.2. Ability by speech style.

\begin{tabular}{lccccc}
\hline \multicolumn{1}{c}{$\begin{array}{l}\text { Source of } \\
\text { Variation }\end{array}$} & $\begin{array}{c}\text { Sum of } \\
\text { Squares }\end{array}$ & df & $\begin{array}{c}\text { Mean } \\
\text { Square }\end{array}$ & $F$ & $\begin{array}{c}\text { Signif } \\
\text { of } F\end{array}$ \\
\hline Main Effects & 36.134 & 2 & 18.067 & 4.889 & .010 \\
$\quad$ Speech Style & 36.134 & 2 & 18.067 & 4.889 & .010 \\
& & & & & \\
Explained & 36.134 & 2 & 18.067 & 4.889 & .010 \\
Residual & 291.927 & 79 & 3.695 & & \\
Total & 328.061 & 81 & 4.050 & & \\
\hline
\end{tabular}

Table C.3.3. Perceived interpersonal relationship: Closeness by speech style.

\begin{tabular}{|c|c|c|c|c|c|}
\hline $\begin{array}{l}\text { Source of } \\
\text { Variation }\end{array}$ & $\begin{array}{r}\text { Sum of } \\
\text { Squares }\end{array}$ & $\mathrm{df}$ & $\begin{array}{l}\text { Mean } \\
\text { Square }\end{array}$ & $F$ & $\begin{array}{l}\text { Signif } \\
\text { of } F\end{array}$ \\
\hline $\begin{array}{l}\text { Main Effects } \\
\text { Speech Style }\end{array}$ & $\begin{array}{l}24.071 \\
24.071\end{array}$ & $\begin{array}{l}2 \\
2\end{array}$ & $\begin{array}{l}12.036 \\
12.036\end{array}$ & $\begin{array}{l}3.950 \\
3.950\end{array}$ & $\begin{array}{l}.023 \\
.023\end{array}$ \\
\hline $\begin{array}{l}\text { Explained } \\
\text { Residual } \\
\text { Tota! }\end{array}$ & $\begin{array}{r}24.071 \\
246.821 \\
270.893 \\
\end{array}$ & $\begin{array}{r}2 \\
81 \\
83 \\
\end{array}$ & $\begin{array}{r}12.036 \\
3.047 \\
3.264 \\
\end{array}$ & 3.950 & .023 \\
\hline
\end{tabular}

Table C.3.4. Generation identification: Female senior citizens by speech style. 
C.4 T-tests: Formal Version

\begin{tabular}{lcccccc}
\hline & $\begin{array}{c}\text { Number } \\
\text { of Cases }\end{array}$ & $\begin{array}{c}\text { Comprehension } \\
\text { Mean }\end{array}$ & SD & i-value & df & $\begin{array}{c}\text { 2-tail } \\
\text { prob. }\end{array}$ \\
\hline Native & 28 & 6.1786 & 1.492 & & & \\
Non-native & 28 & 6.2857 & 1.243 & -.29 & 54 & .771 \\
\hline
\end{tabular}

Table C.4.1. Comprehension.

\begin{tabular}{lcccccc} 
& $\begin{array}{c}\text { Number } \\
\text { of Cases }\end{array}$ & $\begin{array}{c}\text { Ability } \\
\text { Mean }\end{array}$ & SD & t-value & df & $\begin{array}{c}\text { 2-tail } \\
\text { prob. }\end{array}$ \\
\hline Native & 28 & 6.0357 & 1.427 & & & \\
Non-native & 28 & 5.5357 & 1.374 & 1.34 & 54 & .187 \\
\hline
\end{tabular}

Table C.4.2. Ability.

\begin{tabular}{lcccccc}
\hline & $\begin{array}{c}\text { Number } \\
\text { of Cases }\end{array}$ & $\begin{array}{c}\text { Informality } \\
\text { Mean }\end{array}$ & SD & t-value & df & $\begin{array}{c}\text { 2-tail } \\
\text { prob. }\end{array}$ \\
\hline Native & 28 & 3.7143 & 2.158 & & & \\
Non-native & 28 & 5.1429 & 2.172 & -2.47 & 54 & .017 \\
\hline
\end{tabular}

Table C.4.3. Perceived interpersonal relationship (Informality).

\begin{tabular}{lcccccc}
\hline & $\begin{array}{c}\text { Number } \\
\text { of Cases }\end{array}$ & $\begin{array}{c}\text { Efficiency } \\
\text { Mean }\end{array}$ & SD & t-value & df & $\begin{array}{c}\text { 2-tail } \\
\text { prob. }\end{array}$ \\
\hline Native & 28 & 2.5000 & 1.291 & & & \\
Non-native & 28 & 4.3571 & 1.850 & -4.36 & 54 & $<.001$ \\
\hline
\end{tabular}

Table C.4.4. Perceived interpersonal relationship (Efficiency).

\begin{tabular}{lcccccc}
\hline & $\begin{array}{c}\text { Number } \\
\text { of Cases }\end{array}$ & $\begin{array}{c}\text { Flexibility } \\
\text { Mean }\end{array}$ & SD & t-value & df & $\begin{array}{c}\text { 2-tail } \\
\text { prob. }\end{array}$ \\
\hline Native & 28 & 2.8214 & 1.588 & & & \\
Non-native & 28 & 3.3571 & 1.615 & -1.25 & 54 & .216 \\
\hline
\end{tabular}

Table C.4.5. Perceived interpersonal relationship (Flexibility). 


\begin{tabular}{lcccccc}
\hline & $\begin{array}{c}\text { Number } \\
\text { of Cases }\end{array}$ & $\begin{array}{c}\text { Smoothness } \\
\text { Mean }\end{array}$ & SD & t-value & df & $\begin{array}{c}\text { 2-tail } \\
\text { prob. }\end{array}$ \\
\hline Native & 28 & 2.5714 & 1.752 & & & \\
Non-native & 28 & 3.4286 & 1.854 & -1.78 & 54 & .081 \\
\hline
\end{tabular}

Table C.4.6. Perceived interpersonal relationship (Smoothness).

\begin{tabular}{lcccccc}
\hline & $\begin{array}{c}\text { Number } \\
\text { of Cases }\end{array}$ & $\begin{array}{c}\text { Spontaneity } \\
\text { Mean }\end{array}$ & SD & t-value & df & $\begin{array}{c}\text { 2-tail } \\
\text { prob. }\end{array}$ \\
\hline Native & 28 & 3.5714 & 1.854 & & & \\
Non-native & 27 & 3.9630 & 1.990 & -.76 & 53 & .453 \\
\hline
\end{tabular}

Table C.4.7. Perceived interpersonal relationship (Spontaneity).

\begin{tabular}{lcccccc}
\hline & $\begin{array}{c}\text { Number } \\
\text { of Cases }\end{array}$ & $\begin{array}{c}\text { Closeness } \\
\text { Mean }\end{array}$ & SD & t-value & df & $\begin{array}{c}\text { 2-tail } \\
\text { prob. }\end{array}$ \\
\hline Native & 28 & 4.1071 & 1.950 & & & \\
Non-native & 28 & 3.7857 & 2.025 & .61 & 54 & .548 \\
\hline
\end{tabular}

Table C.4.8. Perceived interpersonal relationship (Closeness).

\begin{tabular}{lcccccc}
\hline & $\begin{array}{c}\text { Number } \\
\text { of Cases }\end{array}$ & $\begin{array}{c}\text { Teen-agers } \\
\text { Mean }\end{array}$ & SD & t-value & df & $\begin{array}{c}\text { 2-tail } \\
\text { prob. }\end{array}$ \\
\hline Native & 28 & 3.5714 & 2.441 & & & \\
Non-native & 28 & 4.1071 & 2.200 & -.86 & 54 & .392 \\
\hline
\end{tabular}

Table C.4.9. Generation identification (Female teen-agers).

\begin{tabular}{lcccccc}
\hline & $\begin{array}{c}\text { Number } \\
\text { of Cases }\end{array}$ & $\begin{array}{c}\text { College } \\
\text { Mean }\end{array}$ & SD & t-value & df & $\begin{array}{c}\text { 2-tail } \\
\text { prob. }\end{array}$ \\
\hline Native & 28 & 3.5714 & 1.913 & & & \\
Non-native & 28 & 4.1071 & 1.931 & -1.04 & 54 & .302 \\
\hline
\end{tabular}

Table C.4.10. Generation identification (Female college students). 


\begin{tabular}{lcccccc}
\hline & $\begin{array}{c}\text { Number } \\
\text { of Cases }\end{array}$ & $\begin{array}{c}\text { Mid-Aged } \\
\text { Mean }\end{array}$ & SD & t-value & df & $\begin{array}{c}\text { 2-tail } \\
\text { prob. }\end{array}$ \\
\hline Native & 28 & 3.3929 & 1.873 & -.22 & 54 & .829 \\
Non-native & 28 & 3.5000 & 1.816 & & 54 & \\
\hline
\end{tabular}

Table C.4.11. Generation identification (Middle-aged women).

\begin{tabular}{lcccccc}
\hline & $\begin{array}{c}\text { Number } \\
\text { of Cases }\end{array}$ & $\begin{array}{c}\text { Senior } \\
\text { Mean }\end{array}$ & SD & t-value & df & $\begin{array}{c}\text { 2-tail } \\
\text { prob. }\end{array}$ \\
\hline Native & 28 & 3.107 & 2.006 & & & \\
Non-native & 28 & 2.9286 & 1.999 & .33 & 54 & .740 \\
\hline
\end{tabular}

Table C.4.12. Generation identification (Female senior citizens). 
C.5 T-tests: Natural Version

\begin{tabular}{lcccccc}
\hline & $\begin{array}{c}\text { Number } \\
\text { of Cases }\end{array}$ & $\begin{array}{c}\text { Comprehension } \\
\text { Mean }\end{array}$ & SD & t-value & df & $\begin{array}{c}\text { 2-tail } \\
\text { prob. }\end{array}$ \\
\hline Native & 28 & 6.0714 & 1.464 & & & \\
Non-native & 28 & 5.8214 & 1.634 & .60 & 54 & .549 \\
\hline
\end{tabular}

Table C.5.1. Comprehension.

\begin{tabular}{lcccccc}
\hline & $\begin{array}{c}\text { Number } \\
\text { of Cases }\end{array}$ & $\begin{array}{c}\text { Ability } \\
\text { Mean }\end{array}$ & SD & t-value & df & $\begin{array}{c}\text { 2-tail } \\
\text { prob. }\end{array}$ \\
\hline Native & 28 & 6.1071 & 1.571 & & & \\
Non-native & 28 & 4.7143 & 1.272 & 3.64 & 54 & .001 \\
\hline
\end{tabular}

Table C.5.2. Ability.

\begin{tabular}{lcccccc}
\hline & $\begin{array}{c}\text { Number } \\
\text { of Cases }\end{array}$ & $\begin{array}{c}\text { Informality } \\
\text { Mean }\end{array}$ & SD & t-value & df & $\begin{array}{c}\text { 2-tail } \\
\text { prob. }\end{array}$ \\
\hline Native & 28 & 6.2500 & 1.578 & & & \\
Non-native & 28 & 5.1786 & 1.786 & 2.38 & 54 & .021 \\
\hline
\end{tabular}

Table C.5.3. Perceived interpersonal relationship (Informality).

\begin{tabular}{lcccccc}
\hline & $\begin{array}{c}\text { Number } \\
\text { of Cases }\end{array}$ & $\begin{array}{c}\text { Efficiency } \\
\text { Mean }\end{array}$ & SD & t-value & df & $\begin{array}{c}\text { 2-tail } \\
\text { prob. }\end{array}$ \\
\hline Native & 28 & 4.5714 & 1.834 & & & \\
Non-native & 28 & 3.7857 & 1.663 & 1.68 & 54 & .099 \\
\hline
\end{tabular}

Table C.5.4. Perceived interpersonal relationship (Efficiency).

\begin{tabular}{lcccccc}
\hline & $\begin{array}{c}\text { Number } \\
\text { of Cases }\end{array}$ & $\begin{array}{c}\text { Flexibility } \\
\text { Mean }\end{array}$ & SD & t-value & df & $\begin{array}{c}\text { 2-tail } \\
\text { prob. }\end{array}$ \\
\hline Native & 28 & 4.8214 & 1.442 & & & \\
Non-native & 28 & 4.1429 & 1.557 & & 54 & .096 \\
\hline
\end{tabular}

Table C.5.5. Perceived interpersonal relationship (Flexibility). 


\begin{tabular}{lcccccc}
\hline & $\begin{array}{c}\text { Number } \\
\text { of Cases }\end{array}$ & $\begin{array}{c}\text { Smoothness } \\
\text { Mean }\end{array}$ & SD & t-value & df & $\begin{array}{c}\text { 2-tail } \\
\text { prob. }\end{array}$ \\
\hline Native & 28 & 4.5000 & 1.732 & 1.14 & 54 & .261 \\
Non-native & 28 & 3.9643 & 1.795 & & & \\
\hline
\end{tabular}

Table C.5.6. Perceived interpersonal relationship (Smoothness).

\begin{tabular}{lcccccc}
\hline & $\begin{array}{c}\text { Number } \\
\text { of Cases }\end{array}$ & $\begin{array}{c}\text { Spontaneity } \\
\text { Mean }\end{array}$ & SD & t-value & df & $\begin{array}{c}\text { 2-tail } \\
\text { prob. }\end{array}$ \\
\hline Native & 28 & 5.5357 & 1.261 & & & \\
Non-native & 28 & 4.5357 & 1.990 & 2.25 & 54 & .029 \\
\hline
\end{tabular}

Table C.5.7. Perceived interpersonal relationship (Spontaneity).

\begin{tabular}{lcccccc}
\hline & $\begin{array}{c}\text { Number } \\
\text { of Cases }\end{array}$ & $\begin{array}{c}\text { Closeness } \\
\text { Mean }\end{array}$ & SD & t-value & df & $\begin{array}{c}\text { 2-tail } \\
\text { prob. }\end{array}$ \\
\hline Native & 28 & 5.4643 & 1.138 & & & \\
Non-native & 28 & 4.0357 & 1.972 & 3.32 & 54 & .002 \\
\hline
\end{tabular}

Table C.5.8. Perceived interpersonal relationship (Closeness).

\begin{tabular}{lcccccc}
\hline & $\begin{array}{c}\text { Number } \\
\text { of Cases }\end{array}$ & $\begin{array}{c}\text { Teen-Agers } \\
\text { Mean }\end{array}$ & SD & t-value & df & $\begin{array}{c}\text { 2-tail } \\
\text { prob. }\end{array}$ \\
\hline Native & 28 & 5.9286 & 1.152 & & & \\
Non-native & 28 & 5.2500 & 1.430 & 1.95 & 54 & .056 \\
\hline
\end{tabular}

Table C.5.9. Generation identification (Female teen-agers).

\begin{tabular}{lcccccc}
\hline & $\begin{array}{c}\text { Number } \\
\text { of Cases }\end{array}$ & $\begin{array}{c}\text { College } \\
\text { Mean }\end{array}$ & SD & t-value & df & $\begin{array}{c}\text { 2-tail } \\
\text { prob. }\end{array}$ \\
\hline Native & 28 & 4.9643 & 1.478 & & & \\
Non-native & 28 & 4.4286 & 1.643 & & 54 & .205 \\
\hline
\end{tabular}

Table C.5.10. Generation identification (Female college students). 


\begin{tabular}{lcccccc}
\hline & $\begin{array}{c}\text { Number } \\
\text { of Cases }\end{array}$ & $\begin{array}{c}\text { Mid-Aged } \\
\text { Mean }\end{array}$ & SD & t-value & df & $\begin{array}{c}\text { 2-tail } \\
\text { prob. }\end{array}$ \\
\hline Native & 28 & 2.1429 & 1.325 & & & \\
Non-native & 28 & 3.3929 & 1.595 & -3.19 & 54 & .002 \\
\hline
\end{tabular}

Table C.5.11. Generation identification (Middle-aged woraen).

\begin{tabular}{lcccccc}
\hline & $\begin{array}{c}\text { Number } \\
\text { of Cases }\end{array}$ & $\begin{array}{c}\text { Senior } \\
\text { Mean }\end{array}$ & SD & t-value & df & $\begin{array}{c}\text { 2-tail } \\
\text { prob. }\end{array}$ \\
\hline Native & 28 & 1.1786 & .476 & & & \\
Non-native & 28 & 2.7500 & 1.798 & -4.47 & 54 & $<.001$ \\
\hline
\end{tabular}

Table C.5.12. Generation identification (Female senior citizens). 
C. 6 T-tests: Idiomatic Version

\begin{tabular}{lcccccc}
\hline & $\begin{array}{c}\text { Number } \\
\text { of Cases }\end{array}$ & $\begin{array}{c}\text { Comprehension } \\
\text { Mean }\end{array}$ & SD & t-value & df & $\begin{array}{c}\text { 2-tail } \\
\text { prob. }\end{array}$ \\
\hline Native & 28 & 6.4643 & .693 & & & \\
Non-native & 28 & 4.9286 & 1.215 & 5.81 & 54 & $<.001$ \\
\hline
\end{tabular}

Table C.6.1. Comprehension.

\begin{tabular}{|c|c|c|c|c|c|c|}
\hline & $\begin{array}{l}\text { Number } \\
\text { of Cases }\end{array}$ & $\begin{array}{l}\text { Ability } \\
\text { Mean }\end{array}$ & $\mathrm{SD}$ & t-value & $\mathrm{df}$ & $\begin{array}{l}\text { 2-tail } \\
\text { prob. }\end{array}$ \\
\hline Native & 28 & 5.6429 & 1.367 & \multirow[b]{2}{*}{3.84} & \multirow[b]{2}{*}{54} & \multirow[b]{2}{*}{$<.001$} \\
\hline Non-native & 28 & 3.9286 & 1.923 & & & \\
\hline
\end{tabular}

Table C.6.2. Ability.

\begin{tabular}{lcccccc}
\hline & $\begin{array}{c}\text { Number } \\
\text { of Cases }\end{array}$ & $\begin{array}{c}\text { Informality } \\
\text { Mean }\end{array}$ & SD & t-value & df & $\begin{array}{c}\text { 2-tail } \\
\text { prob. }\end{array}$ \\
\hline Native & 28 & 6.8929 & .315 & & & \\
Non-native & 28 & 5.5000 & 1.876 & 3.87 & 54 & $<.001$ \\
\hline
\end{tabular}

Table C.6.3. Perceived interpersonal relationship (Informality).

\begin{tabular}{lcccccc}
\hline & $\begin{array}{c}\text { Number } \\
\text { of Cases }\end{array}$ & $\begin{array}{c}\text { Efficiency } \\
\text { Mean }\end{array}$ & SD & t-value & df & $\begin{array}{c}\text { 2-tail } \\
\text { prob. }\end{array}$ \\
\hline Native & 28 & 4.0714 & 1.654 & & & \\
Non-native & 28 & 4.4643 & 1.710 & -.87 & 54 & .386 \\
\hline
\end{tabular}

Table C.6.4. Perceived interpersonal relationship (Efficiency).

\begin{tabular}{lcccccc}
\hline & $\begin{array}{c}\text { Number } \\
\text { of Cases }\end{array}$ & $\begin{array}{c}\text { Flexibility } \\
\text { Mean }\end{array}$ & $\mathrm{SD}$ & t-value & df & $\begin{array}{c}\text { 2-tail } \\
\text { prob. }\end{array}$ \\
\hline Native & 28 & 5.3214 & 1.541 & & & \\
Non-native & 28 & $4<.001$ & 1.710 & 3.01 & 54 & .004 \\
\hline
\end{tabular}

Table C.6.5. Ferceived interpersonal relationship (Flexibility). 


\begin{tabular}{lcccccc}
\hline & $\begin{array}{c}\text { Number } \\
\text { of Cases }\end{array}$ & $\begin{array}{c}\text { Smoothness } \\
\text { Mean }\end{array}$ & SD & t-value & df & $\begin{array}{c}\text { 2-tail } \\
\text { prob. }\end{array}$ \\
\hline Native & 28 & 3.6429 & 1.789 & & & \\
Non-native & 28 & 3.3571 & 1.909 & .58 & 54 & .566 \\
\hline
\end{tabular}

Table C.6.6. Perceived interpersonal relationship (Smoothness).

\begin{tabular}{lcccccc}
\hline & $\begin{array}{c}\text { Number } \\
\text { of Cases }\end{array}$ & $\begin{array}{c}\text { Spontaneity } \\
\text { Mean }\end{array}$ & SD & t-value & df & $\begin{array}{c}\text { 2-tail } \\
\text { prob. }\end{array}$ \\
\hline Native & 28 & 5.7857 & 1.500 & 2.55 & 54 & .014 \\
Non-native & 28 & 4.6786 & 1.744 & 2.55 & & \\
\hline
\end{tabular}

Table C.6.7. Perceived interpersonal relationship (Spontaneity).

\begin{tabular}{lcccccc}
\hline & $\begin{array}{c}\text { Number } \\
\text { of Cases }\end{array}$ & $\begin{array}{c}\text { Closeness } \\
\text { Mean }\end{array}$ & SD & t-value & df & $\begin{array}{c}\text { 2-tail } \\
\text { prob. }\end{array}$ \\
\hline Native & 28 & 5.5000 & 1.291 & & & \\
Non-native & 28 & 5.3214 & 1.786 & .43 & 54 & .670 \\
\hline
\end{tabular}

Table C.6.8. Perceived interpersonal relationship (Closeness).

\begin{tabular}{lcccccc}
\hline & $\begin{array}{c}\text { Number } \\
\text { of Cases }\end{array}$ & $\begin{array}{c}\text { Teen-Agers } \\
\text { Mean }\end{array}$ & SD & t-value & df & $\begin{array}{c}\text { 2-tail } \\
\text { prob. }\end{array}$ \\
\hline Native & 28 & 6.0357 & .922 & & & \\
Non-native & 28 & 4.8929 & 1.663 & 3.18 & 54 & .002 \\
\hline
\end{tabular}

Table C.6.9. Generation identification (Female teen-agers).

\begin{tabular}{lcccccc}
\hline & $\begin{array}{c}\text { Number } \\
\text { of Cases }\end{array}$ & $\begin{array}{c}\text { College } \\
\text { Mean }\end{array}$ & SD & t-value & df & $\begin{array}{c}\text { 2-tail } \\
\text { prob. }\end{array}$ \\
\hline Native & 28 & 4.6429 & 1.283 & & & \\
Non-native & 27 & 3.8889 & 1.805 & 1.79 & 53 & .079 \\
\hline
\end{tabular}

Table C.6.10. Generation identification (Female college students). 


\begin{tabular}{lcccccc}
\hline & $\begin{array}{c}\text { Number } \\
\text { of Cases }\end{array}$ & $\begin{array}{c}\text { Mid-Aged } \\
\text { Mean }\end{array}$ & SD & t-value & df & $\begin{array}{c}\text { 2-tail } \\
\text { prob. }\end{array}$ \\
\hline Native & 28 & 1.8929 & 1.031 & & & \\
Non-native & 28 & 2.5357 & 1.427 & -1.93 & 54 & .059 \\
\hline
\end{tabular}

Table C.6.11. Generation identification (Middle-aged women).

\begin{tabular}{lcccccc}
\hline & $\begin{array}{c}\text { Number } \\
\text { of Cases }\end{array}$ & $\begin{array}{c}\text { Senior } \\
\text { Mean }\end{array}$ & SD & t-value & df & $\begin{array}{c}\text { 2-tail } \\
\text { prob. }\end{array}$ \\
\hline Native & 28 & 1.1786 & .612 & & & \\
Non-native & 28 & 1.7143 & 1.384 & -1.87 & 54 & .066 \\
\hline
\end{tabular}

Table C.6.12. Generation identification (Female senior citizens). 
C.7 T-tests: Comfortableness in Using Idioms

\begin{tabular}{lcccccc}
\hline & $\begin{array}{c}\text { Number } \\
\text { of Cases }\end{array}$ & $\begin{array}{c}\text { Church } \\
\text { Mean }\end{array}$ & SD & t-value & df & $\begin{array}{c}\text { 2-tail } \\
\text { prob. }\end{array}$ \\
\hline Native & 79 & 3.2025 & 1.842 & -3.34 & 93 & .001 \\
Non-native & 16 & 4.9375 & 2.144 & & & \\
\hline
\end{tabular}

Table C.7.1 In church.

\begin{tabular}{lcccccc}
\hline & $\begin{array}{c}\text { Number } \\
\text { of Cases }\end{array}$ & $\begin{array}{c}\text { Work } \\
\text { Mean }\end{array}$ & SD & t-value & df & $\begin{array}{c}\text { 2-tail } \\
\text { prob. }\end{array}$ \\
\hline Native & 83 & 4.1084 & 1.732 & & & \\
Non-native & 46 & 5.3043 & 1.576 & -3.88 & 127 & $<.001$ \\
\hline
\end{tabular}

Table C.7.2 At work. 